\title{
Grade 2114: Flexure Strength and Elastic Properties
}

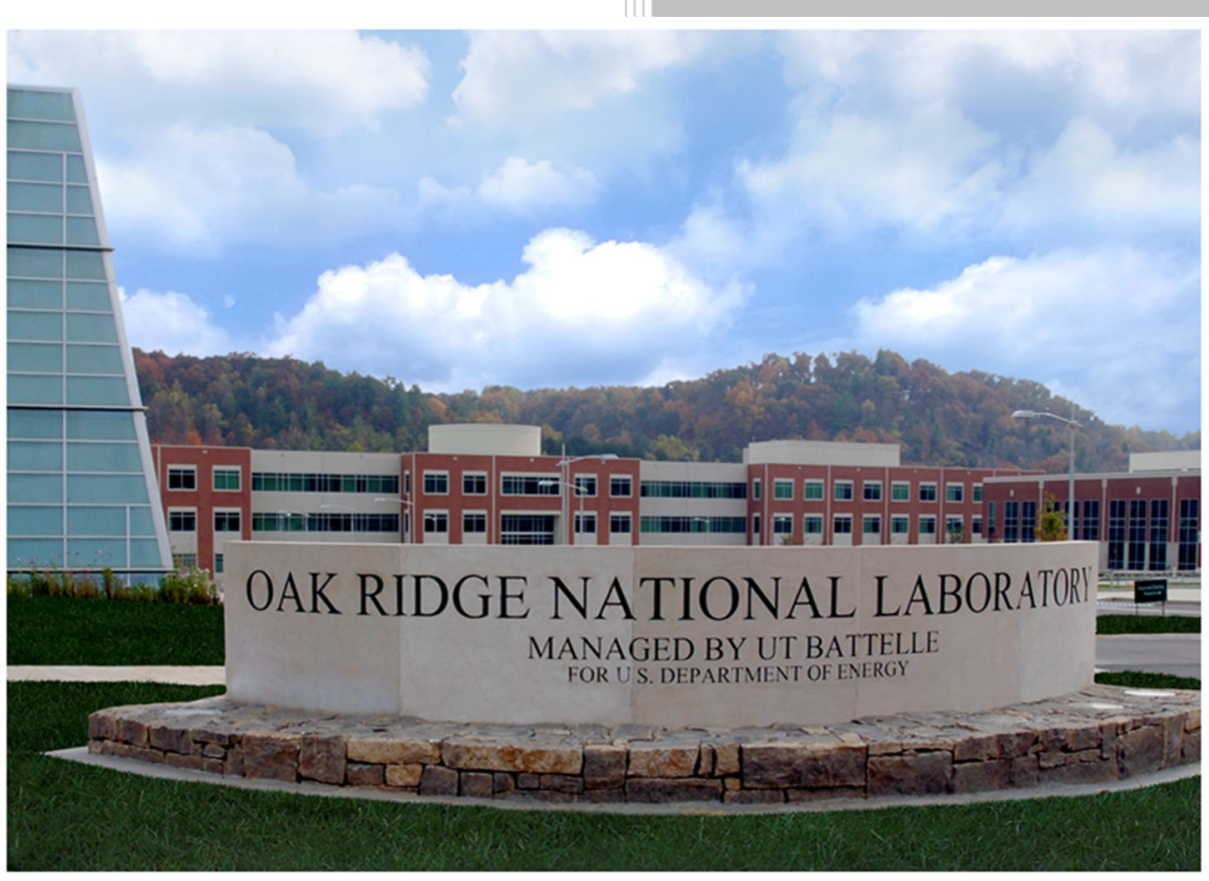

Approved for public release.

Distribution is unlimited.

Timothy D. Burchell

September 2019 


\title{
DOCUMENT AVAILABILITY
}

Reports produced after January 1, 1996, are generally available free via US Department of Energy (DOE) SciTech Connect.

Website www.osti.gov

Reports produced before January 1, 1996, may be purchased by members of the public from the following source:

\author{
National Technical Information Service \\ 5285 Port Royal Road \\ Springfield, VA 22161 \\ Telephone 703-605-6000 (1-800-553-6847) \\ TDD 703-487-4639 \\ Fax 703-605-6900 \\ E-mail info@ntis.gov \\ Website http://classic.ntis.gov/
}

Reports are available to DOE employees, DOE contractors, Energy Technology Data Exchange representatives, and International Nuclear Information System representatives from the following source:

Office of Scientific and Technical Information

PO Box 62

Oak Ridge, TN 37831

Telephone 865-576-8401

Fax 865-576-5728

E-mail reports@osti.gov

Website http://www.osti.gov/contact.html

This report was prepared as an account of work sponsored by an agency of the United States Government. Neither the United States Government nor any agency thereof, nor any of their employees, makes any warranty, express or implied, or assumes any legal liability or responsibility for the accuracy, completeness, or usefulness of any information, apparatus, product, or process disclosed, or represents that its use would not infringe privately owned rights. Reference herein to any specific commercial product, process, or service by trade name, trademark, manufacturer, or otherwise, does not necessarily constitute or imply its endorsement, recommendation, or favoring by the United States Government or any agency thereof. The views and opinions of authors expressed herein do not necessarily state or reflect those of the United States Government or any agency thereof. 
Material Science and Technology Division

\title{
GRADE 2114: FLEXURE STRENGTH AND ELASTIC PROPERTIES
}

\author{
Timothy D. Burchell
}

Date Published: September 2019

Prepared by

OAK RIDGE NATIONAL LABORATORY

Oak Ridge, TN 37831-6283

managed by

UT-BATTELLE, LLC

for the

US DEPARTMENT OF ENERGY

under contract DE-AC05-00OR22725 



\section{CONTENTS}

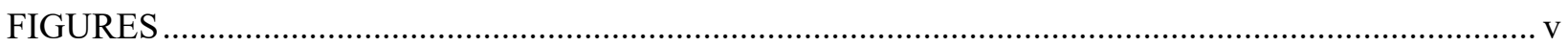

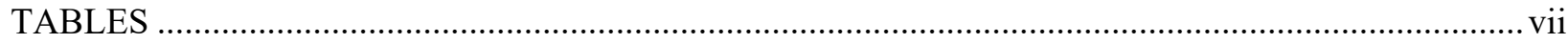

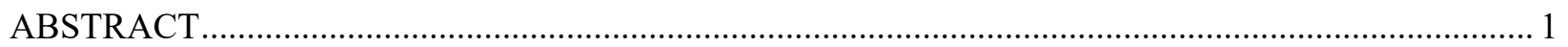

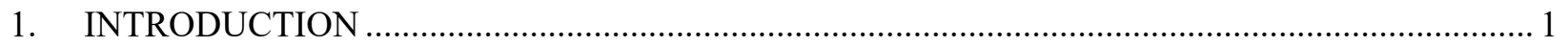

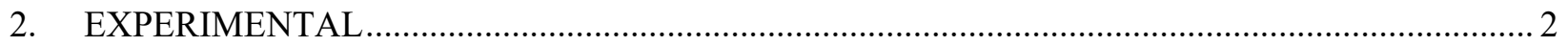

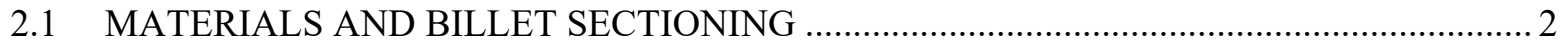

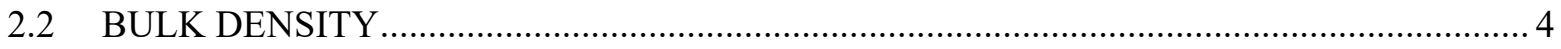

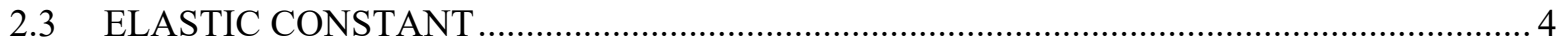

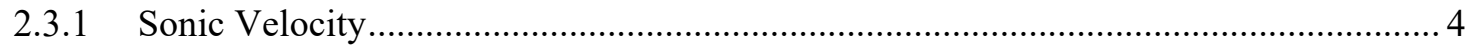

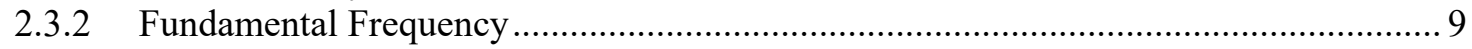

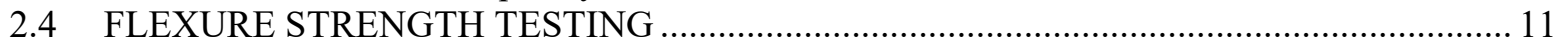

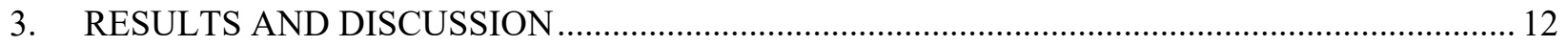

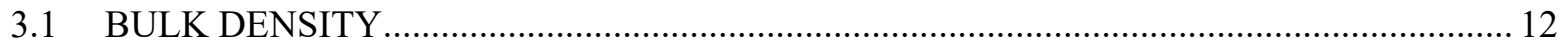

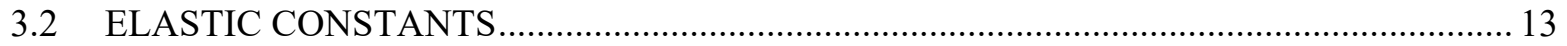

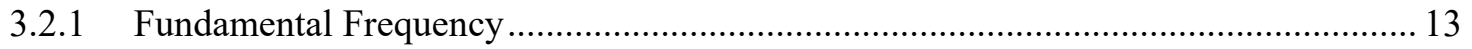

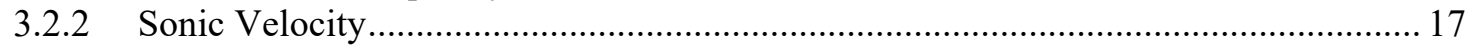

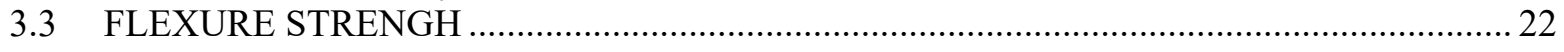

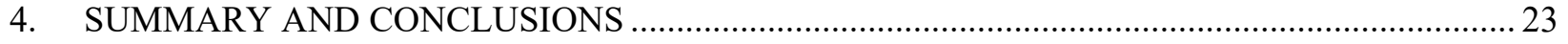

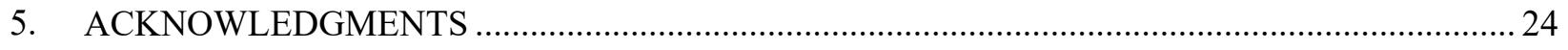

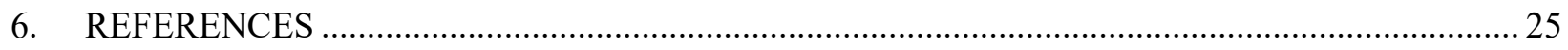

APPENDIX A. EXPERIMENTAL DATA AND CALCULATED VALUES …............................... A-1 



\section{FIGURES}

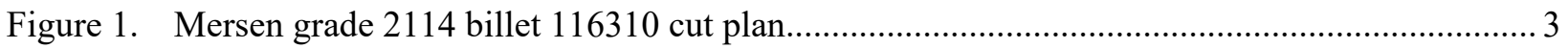

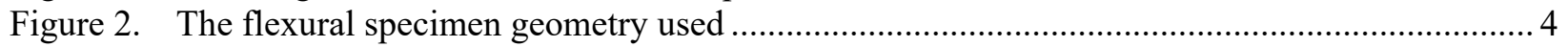

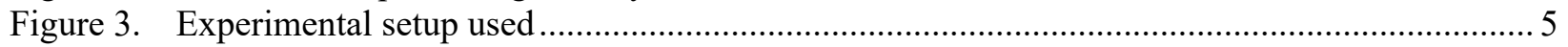

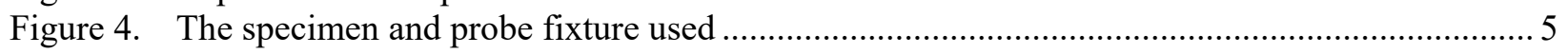

Figure 5. Time-of-flight (ultrasonic velocity) measurements ......................................................... 6

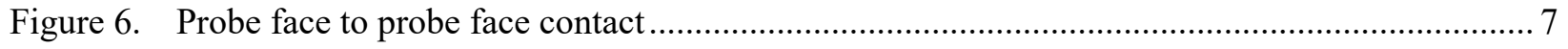

Figure 7. Typical longitudinal wave form (Time-of-flight $=2.988 \mathrm{E}-5 \mathrm{~s})$........................................... 7

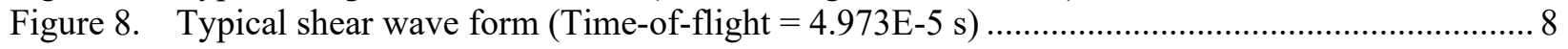

Figure 9. GrindoSonic Mk5 fundamental frequency modulus system................................................ 9

Figure 10. Specimen orientations for the flexural vibration mode defining the specimen

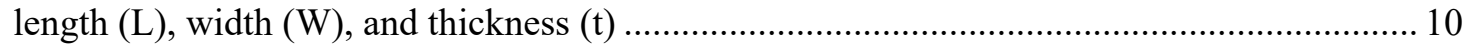

Figure 11. Flexural specimens in two orientations simply supported by narrow strips of

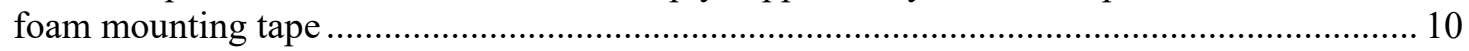

Figure 12. Specimen supported for the torsional vibration mode ….................................................... 11

Figure 13. Typical flexure specimen under test in four-point loading .............................................. 12 



\section{TABLES}

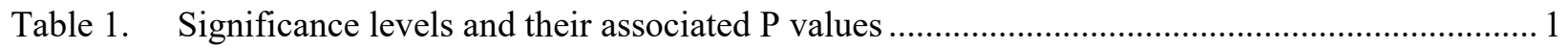

Table 2. Typical properties of Mersen grade 2114 graphite ........................................................... 2

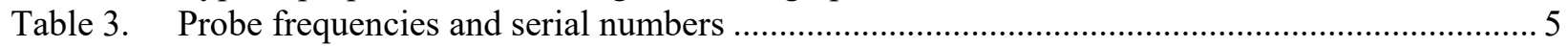

Table 4. Outcome of $t$ testing of the 2114 graphite bulk densities measured on

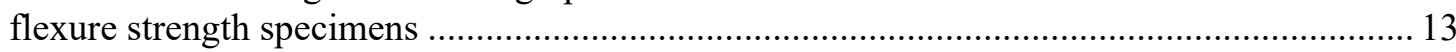

Table 5. Population statistics and outcome of t testing of the 2114 graphite Young's

moduli (by fundamental frequency method) measured on compressive strength

specimens.

Table 6. Population statistics and outcome of t testing of the 2114 graphite Young's

moduli (by fundamental frequency method) measured on flexural strength

specimens in the flat orientation.....

Table 7. Population statistics and outcome of t testing of the 2114 graphite Young's

moduli (by fundamental frequency method) measured on flexural strength

specimens in the flat orientation sorted by grain orientation (WG) and

in-billet position.

Table 8. Population statistics and outcome of $t$ testing of the 2114 graphite Young's

moduli (by fundamental frequency method) measured on flexural strength

specimens in the flat orientation sorted by grain orientation (AG) and

in-billet position.

Table 9. Population statistics and outcome of $t$ testing of the 2114 graphite shear moduli

(by fundamental frequency method) measured on flexural strength specimens in

the torsional mode.

Table 10. Population statistics and outcome of $t$ testing of the 2114 graphite shear moduli

(by fundamental frequency method) measured on flexural strength specimens in the torsional mode for effect of in-billet location

Table 11. Population statistics and outcome of t testing of the 2114 graphite Poisson's ratio (by fundamental frequency method) measured on compressive strength specimens

Table 12. Population statistics and outcome of t testing of the 2114 graphite Poisson's ratio (by fundamental frequency method) measured on flexural strength specimens in the flat orientation, AG against WG

Table 13. Population statistics and outcome of t testing, WG only, of the 2114 graphite Poisson's ratio (by fundamental frequency method) measured on flexural strength

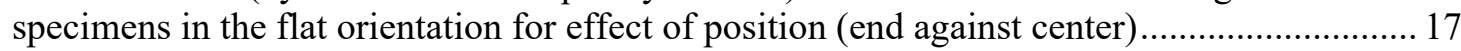

Table 14. Sonic elastic constant's population statistics .................................................................... 17

Table 15. Population statistics and outcome of $t$ testing for sonic shear moduli (G) data from testing in the with and against the grain directions (WG and AG)....

Table 16. Population statistics and outcome of t testing for sonic Poisson's ratio $(\mu)$ data from testing in the with and against the grain directions (WG and AG).....

Table 17. Population statistics and outcome of t testing for sonic Young's moduli [E(Poisson's corrected)] data from testing in the with and against the grain directions (WG and AG)

Table 18. Population statistics and outcome of t testing for sonic Young's moduli (Poisson's corrected) data from testing in the against the grain direction (AG) sorted by in-billet position (End or Center)

Table 19. Population statistics and outcome of $t$ testing for sonic Young's moduli (Poisson's corrected) data from testing in the with the grain direction (WG) sorted by in-billet position (End or Center)

Table 20. Comparison of the elastic constants obtained from the fundamental frequency method (ASTM C747 ${ }^{9}$ ) and the sonic velocity (TOF) method (ASTM C769 ${ }^{8}$ ) 
Table 21. Population statistics and outcome of $t$ testing for against the grain (AG) shear modulus $(\mathrm{G})$ data by sonic velocity (TOF) method and fundamental frequency (ff) method

Table 22. Population statistics and outcome of $t$ testing for with the grain (WG) shear modulus $(\mathrm{G})$ data by sonic velocity (TOF) method and fundamental frequency (ff) method

Table 23. Population statistics and outcome of $t$ testing for against the grain (AG) Poisson's ratio $(\mu)$ data by sonic velocity (TOF) method and fundamental frequency (ff) method

Table 24. Population statistics and outcome of t testing for with the grain (WG) Poisson's ratio $(\mu)$ data by sonic velocity (TOF) method and fundamental frequency (ff) method

Table 25. Population statistics and outcome of $t$ testing for against the grain (AG) Young's modulus (E) data by sonic velocity (TOF) method (Poisson's ratio corrected E) and fundamental frequency (ff) method

Table 26. Population statistics and outcome of t testing for with the grain (WG) Young's modulus (E) data by sonic velocity (TOF) method (Poisson's ratio corrected E) and fundamental frequency (ff) method

Table 27. Data for mean Young's modulus and shear modulus for billets 116310 and 20570 (fundamental frequency method only).

Table 28. Population statistics and outcome of $t$ testing for with and against the grain (WG and $A G)$ flexure strength $(\sigma f)$ of billet 116310

Table 29. Comparison of the mean four-point loading flexural strength of billets 116310 and 20570 (Mersen grade 2114) 


\begin{abstract}
This document reports flexural strength, bulk density, and elastic constants data (the last determined by two separate methods) for Mersen grade 2114, billet 116310. These data are needed to support the design of graphite core components. This technical memorandum is responsive to work package AT-19OR03050405, "Graphite Materials Properties_ORNL."
\end{abstract}

\title{
1. INTRODUCTION
}

To fully characterize the within-billet, between-billet, and batch-to-batch variations of a graphite grade it is necessary to section and test several billets. In this document we report the variability of flexural strength of Mersen grade 2114 graphite, billet 116310. Also, we report certain elastic constants, determined from the ultrasonic velocity in the longitudinal and shear wave modes, and the same elastic constants determined from the fundamental frequency (ff) of vibration. Details of the billet cut plan and specimen drawings are reported for information. The tensile and compressive properties of this billet were reported previously. ${ }^{1}$

To test the physical properties data for systematic variations, i.e., $\sigma_{\mathrm{f}}(\mathrm{WG})=\sigma_{\mathrm{f}}(\mathrm{AG})$ or $\sigma_{\mathrm{f}}($ billet center $)=$ $\sigma_{\mathrm{f}}\left(\right.$ billet periphery), we used statistical significance testing ${ }^{2}$ or hypothesis testing based upon the unpaired $\mathrm{t}_{\text {test }} \mathrm{t}^{3,4}$ result. The significance testing levels used are shown in Table 1.

Table 1. Significance levels and their associated $P$ values

\begin{tabular}{|c|c|}
\hline P Value & Terminology \\
\hline Less than 0.0001 & Extremely Significant \\
\hline $\mathbf{0 . 0 0 0 1}$ to 0.001 & Extremely Significant \\
\hline $\mathbf{0 . 0 0 1}$ to 0.01 & Very Significant \\
\hline 0.01 to 0.05 & Significant \\
\hline Greater than or equal to 0.05 & Not significant \\
\hline
\end{tabular}

The statistical significance of any observed material property difference between location or orientation is determined entirely based on the reported "P" values (a function of the mean and standard deviation), as noted in Table 1 . The conventional threshold of $\mathrm{P}=0.05$ was adopted for hypothesis testing and the null hypothesis was taken as $\sigma_{t}(1)=\sigma_{t}(2)$. If the derived P value was less than the threshold value, it was reported that the "null hypothesis was rejected" and that the difference was "statistically significant." However, if the derived $P$ value was greater than the threshold value $(P \geq 0.05)$, we reported that the null hypothesis was not rejected and that the difference was "not statistically significant."

This work has several broad goals:

- To show that this billet has similar density and elastic properties as previously reported ${ }^{1}$

- To show that the measured properties agreed with manufacturers' literature ${ }^{5}$ (when available)

- To determine the isotropy of the graphite

- To determine that the properties are uniform, i.e., billet center same as billet end

- To show the elastic constants are similar regardless of experimental method 


\section{EXPERIMENTAL}

\subsection{MATERIALS AND BILLET SECTIONING}

All baseline testing reported here was conducted in accordance with the experimental plan. ${ }^{6}$

Mersen grade 2114, billet 116310, was sectioned as shown in the cut plan drawing (Figure 1). The billet was cut into eight typical slabs with slab 1 being the top (end) of the as-molded billet. Each slab was cut into four blocks labeled A, B, C, and D, and each block was further sectioned into four subblocks labeled $1,2,3$, and 4 . To reduce the overall number of specimens, only slabs 1 and 5 were considered for initial testing. Additionally, only subblocks from blocks A and D were sectioned into rectangular specimen blocks from which tensile, compression, and flexure specimens were produced. Typical Mersen grade 2114 properties are given in Table 2.

Table 2. Typical properties of Mersen grade 2114 graphite $^{5}$

\begin{tabular}{|c|c|c|c|c|c|c|}
\hline $\begin{array}{c}\text { Density } \\
\left(\mathbf{g . c m}^{-\mathbf{3}}\right)\end{array}$ & $\begin{array}{c}\text { Grain Size } \\
(\boldsymbol{\mu \mathbf { m } )}\end{array}$ & $\begin{array}{c}\text { Porosity } \\
\mathbf{( \% )}\end{array}$ & $\begin{array}{c}\text { Flexural } \\
\text { Strength } \\
\mathbf{( M P a )}\end{array}$ & $\begin{array}{c}\mathbf{C T E} \\
\left(\mathbf{1 0}{ }^{\mathbf{0}} \mathbf{C}\right)\end{array}$ & $\begin{array}{c}\text { Resistivity }(\boldsymbol{\mu} \\
\mathbf{\Omega} \mathbf{~ c m})\end{array}$ & $\begin{array}{c}\text { Thermal } \\
\text { Conductivity } \\
\left(\mathbf{W} / \mathbf{m}^{\circ} \mathbf{C}\right)\end{array}$ \\
\hline 1.81 & 13 & 10 & 52 & 5.3 & 1240 & 104 \\
\hline
\end{tabular}

$\mathrm{CTE}=$ Coefficient of thermal expansion.

Mersen 2114 grade is an isostatically molded graphite; the saggars (molds) are vertically oriented when filled such that the effect of gravity before isostatic molding is to align the filler-coke particles with the long axis (in-plane covalent bonds) in the billet transverse direction. The axial orientation of the specimens used here were either parallel to or transverse to the billet long axis such that the specimen orientation to the slight (gravitational) preferred orientation was as follows:

Transverse sample $=$ sample axial direction perpendicular to billet long axis $=$ with grain $(\mathrm{WG})$.

Parallel sample $=$ sample axial direction parallel to billet long axis $=$ against grain $(A G)$. 
$\frac{\text { Slab Layout }}{\text { SCALE 1:24 }}$

$\omega$

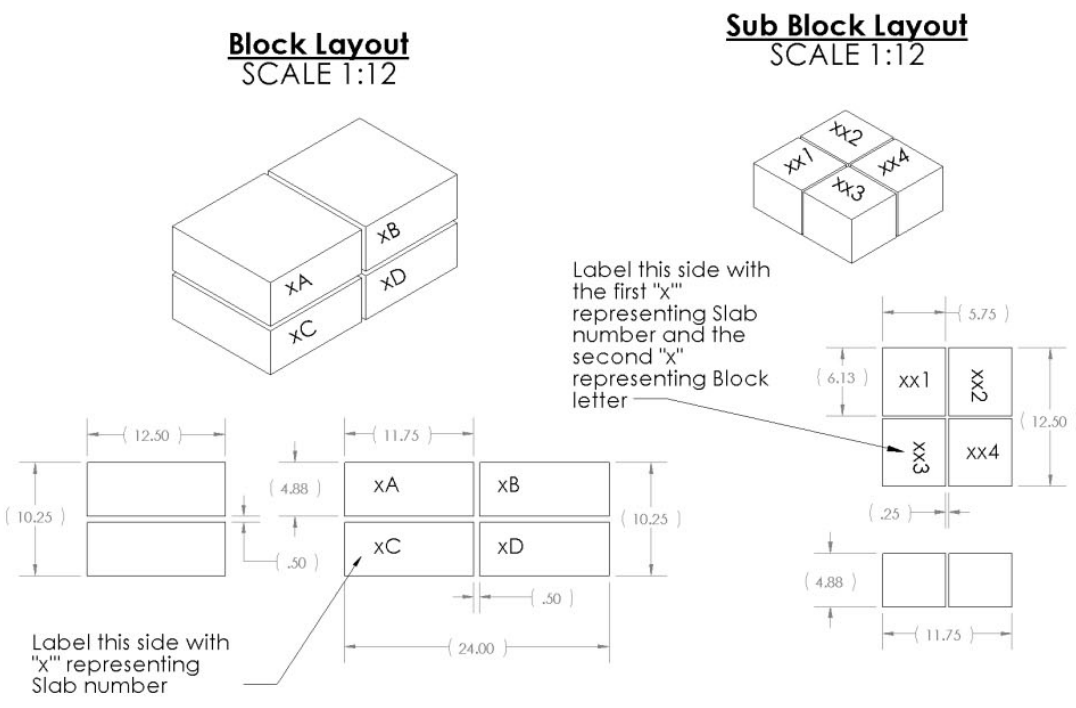

\section{Specimen Block Layout}

Specimen orientation for

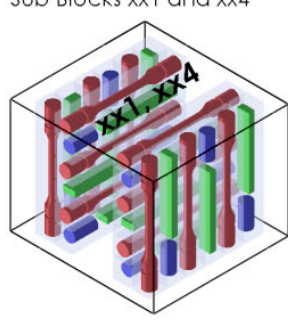

Specimen orientation for

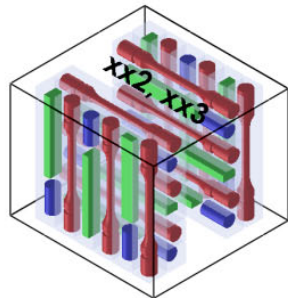
ORIENTAION (P=PARALLLL, T=TRANSSLESC

Specimen Legend

$x-x-x-x-x-x-x$ SAMPILE TPE IIIENSIIE, C=COMPRESSION, F=FLEXURE, FR=FLEXURE ROTAIED
POSIION OR LAYER
ROW

\begin{tabular}{|c|c|c|c|c|c|c|}
\hline \multirow{4}{*}{ 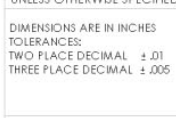 } & & \multirow{2}{*}{ name } & \multirow{2}{*}{ DATE } & \multirow{2}{*}{\multicolumn{3}{|c|}{ ORNL }} \\
\hline & \multirow{3}{*}{$\begin{array}{l}\text { DRAWN } \\
\text { CHECKED } \\
\text { ENG APPR. } \\
\text { MFG APPR. }\end{array}$} & & & & & \\
\hline & & & & \multirow{3}{*}{\multicolumn{3}{|c|}{$\begin{array}{c}\text { TTILE: Cut Plan for } \\
\text { Mersen } 2114 \text { Graphite } \\
\text { Baseline Characterization }\end{array}$}} \\
\hline & & & & & & \\
\hline 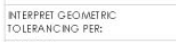 & & & & & & \\
\hline 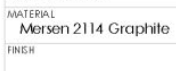 & \multicolumn{3}{|l|}{ COMMENS: } & $\begin{array}{l}\text { SIIE } \\
\mathbf{B}\end{array}$ & $\begin{array}{l}\text { DWG. NO. } \\
12688-01\end{array}$ & $\mathrm{O}^{\text {REV }}$ \\
\hline DO NOT SCALE DRAWNG & & & & SCA & LE: 1:24WEIGHT: NA & SHEET 1 OF 6 \\
\hline
\end{tabular}

Figure 1. Mersen grade 2114 billet 116310 cut plan (for information only—see experimental plan ${ }^{6}$ ). 


\subsection{BULK DENSITY}

The bulk density was determined by mensuration using the flexural strength specimens (Figure 2) in accordance with ASTM C559. ${ }^{7}$

Flexure Specimen

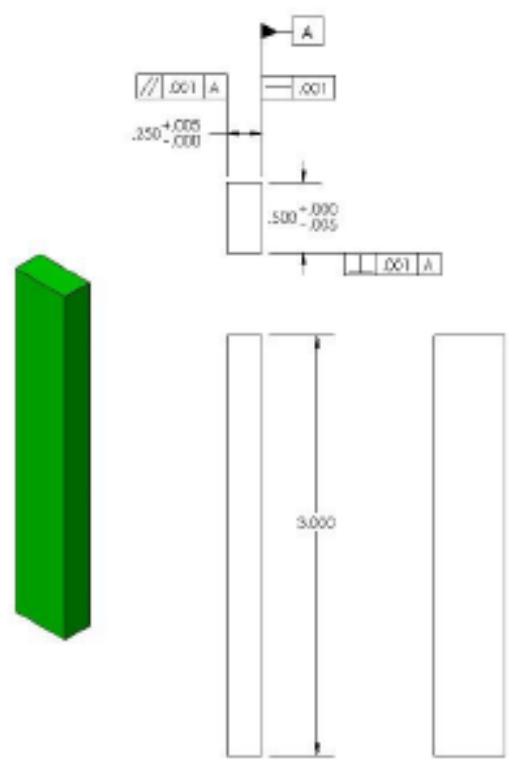

Figure 2. The flexural specimen geometry used (specimen dimensions in inches).

\subsection{ELASTIC CONSTANT}

\subsubsection{Sonic Velocity}

The elastic constants, Young's modulus, shear modulus, and Poisson's ratio were determined from the longitudinal and shear wave velocities measured on the compression test specimen.

Figure 3 shows the experimental setup used. ASTM C $769^{8}$ was followed for determination of the sonic velocities. Details of the probes used are given in Table 3. The couplants used were Ultragel II, manufactured by SonoTech for the longitudinal wave probes, and Shear Gel, manufactured by SonoTech for the shear wave probes.

The longitudinal velocity was determined as the mean of three consistent time-of-flight (TOF) measurements and shear velocity by two measurements taken $90^{\circ}$ apart, each of these also determined as the mean of three consistent TOF measurements. The signal trace was captured by the oscilloscope interface laptop PC. The probes are directly contacting the sample, i.e., there is no stand-off or compliant layer (Figure 4), and therefore there is no zero correction. The TOF measurements and hence ultrasonic velocity are read directly from the laptop PC and are measured between the two moveable cursers, as shown in Figure 5(a). Exact placement of the cursers can be achieved by expanding the initial or final pulse (Figure 5b). Constant probe-specimen pressure is advisable for velocity determinations, especially shear-wave velocity measurements, and was achieved by use of a spring-loaded fixture (Figure 4). The 
signal trace resulting from probe to probe contact (i.e., no specimen) is shown in Figure 6 . The initiating pulse and the transmitted signal are coincident at $\sim 1 \mathrm{E}-5$ seconds, again reinforcing the lack of any zero correction.

A typical ultrasonic longitudinal wave form signal is shown in Figure 7 and a shear wave form signal in Figure 8.

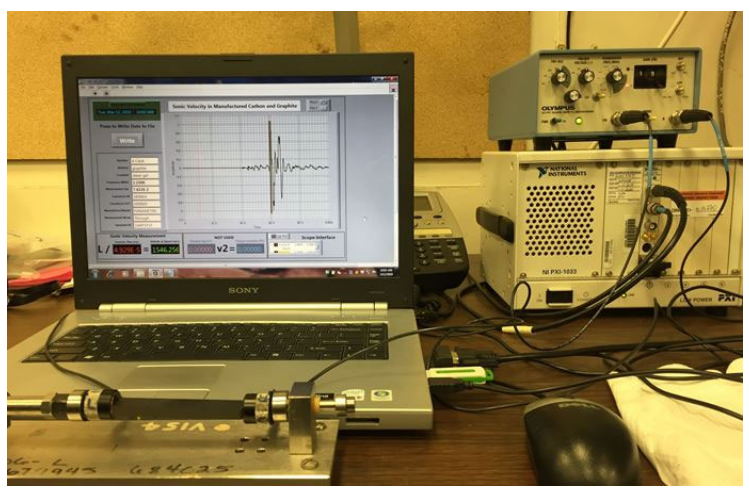

Figure 3. Experimental setup used.

Table 3. Probe frequencies and serial numbers

\begin{tabular}{|c|c|c|c|c|}
\hline Manufacturer & Model & Frequency & Serial Number & Wave Type \\
\hline Panametrics* & V106 & $2.25 \mathrm{MHz}$ & 593888 & Longitudinal \\
\hline Panametrics* & V106 & $2.25 \mathrm{MHz}$ & 593889 & Longitudinal \\
\hline Panametrics* & V154 & $2.25 \mathrm{MHz}$ & 589864 & Shear \\
\hline Panametrics* & V154 & $2.25 \mathrm{MHz}$ & 598869 & Shear \\
\hline
\end{tabular}

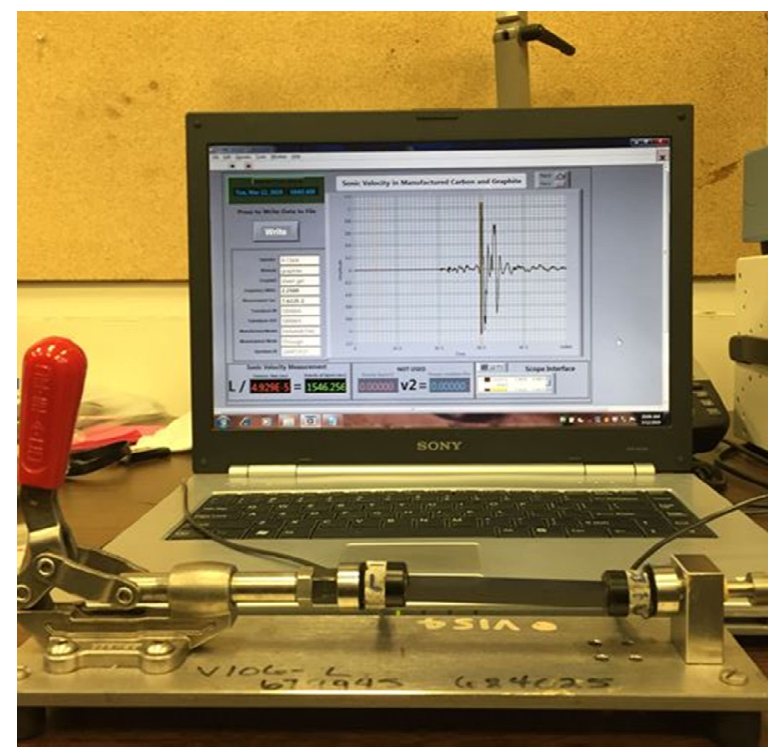

Figure 4. The specimen and probe fixture used. The fixture is spring-loaded to ensure constant probe to specimen contact pressure. 


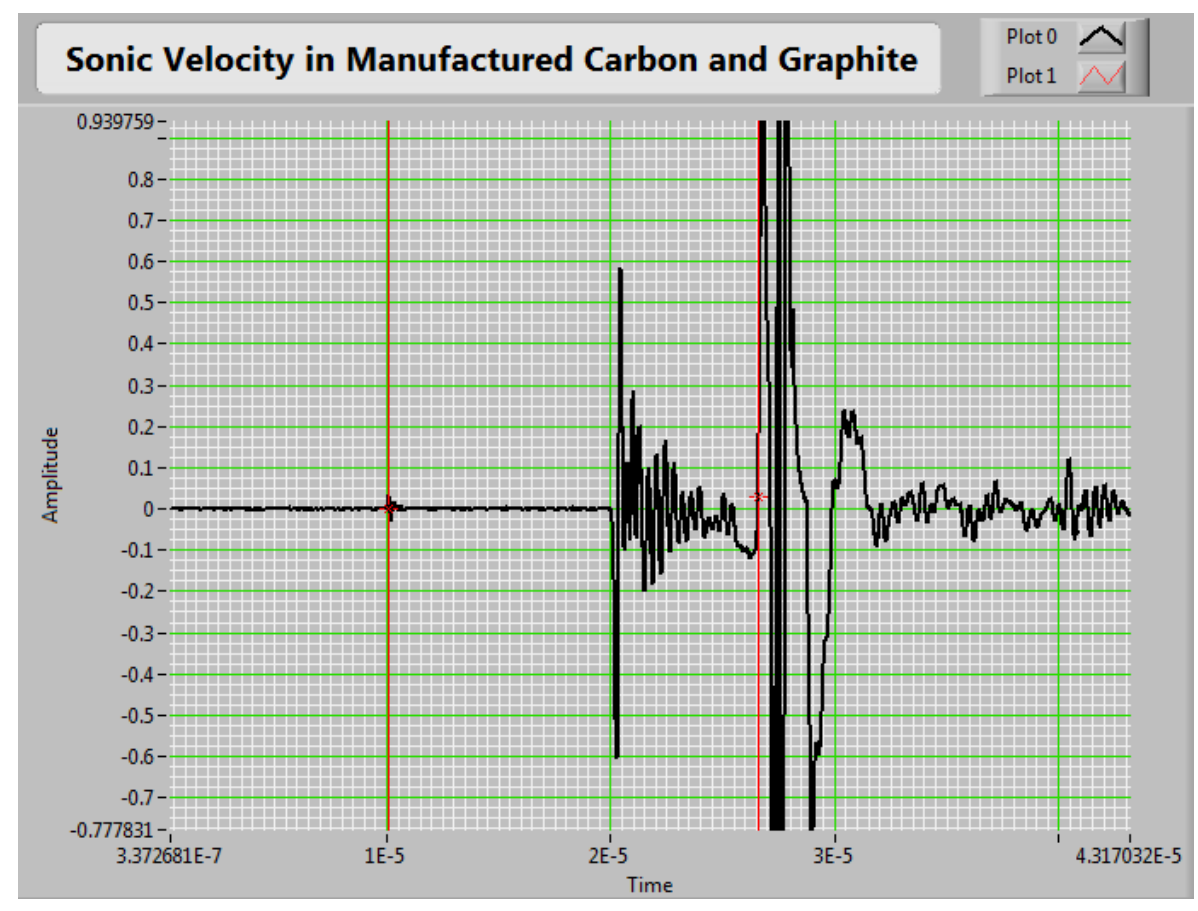

(a)

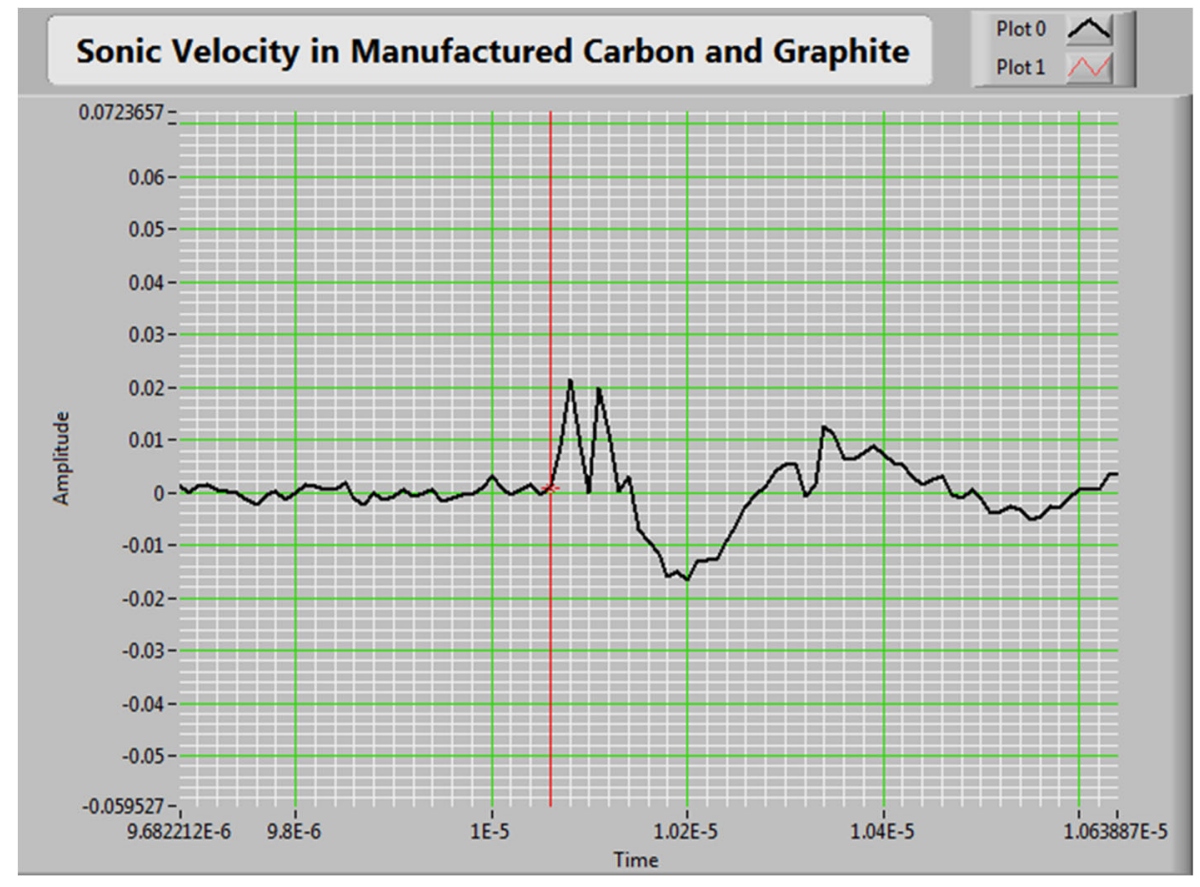

(b)

Figure 5. Time-of-flight (ultrasonic velocity) measurements: (a) typical ultrasonic signal traceshear $(\sim 2.6 \mathrm{E}-5 \mathrm{~s})$ and longitudinal wave ( $\sim 2 \mathrm{E}-5 \mathrm{~s})$, trigger pulse at $1 \mathrm{E}-5$ seconds, and (b) expansion of the initial trigger pulse at $1 \mathrm{E}-5$ seconds. 


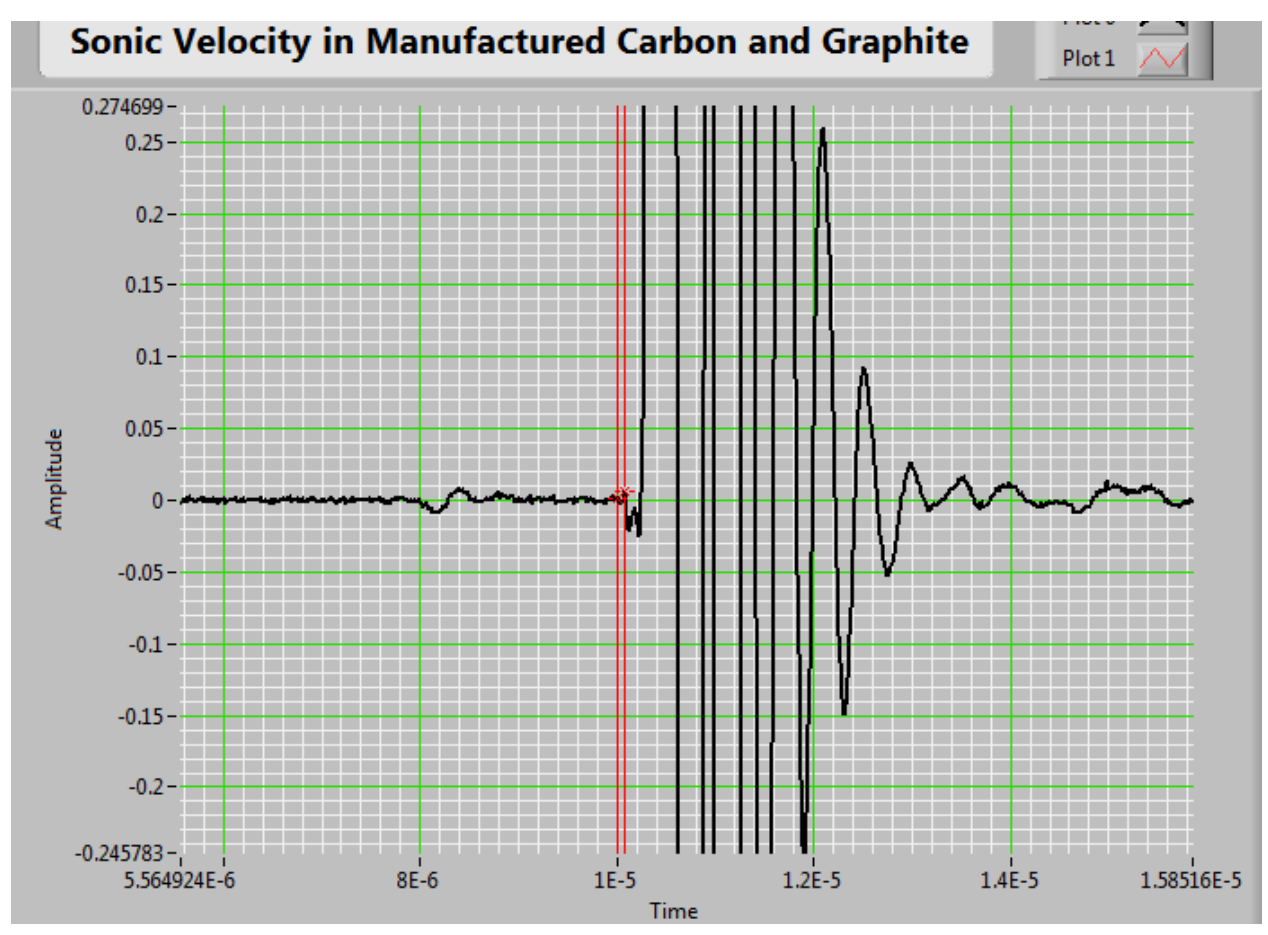

Figure 6. Probe face to probe face contact.

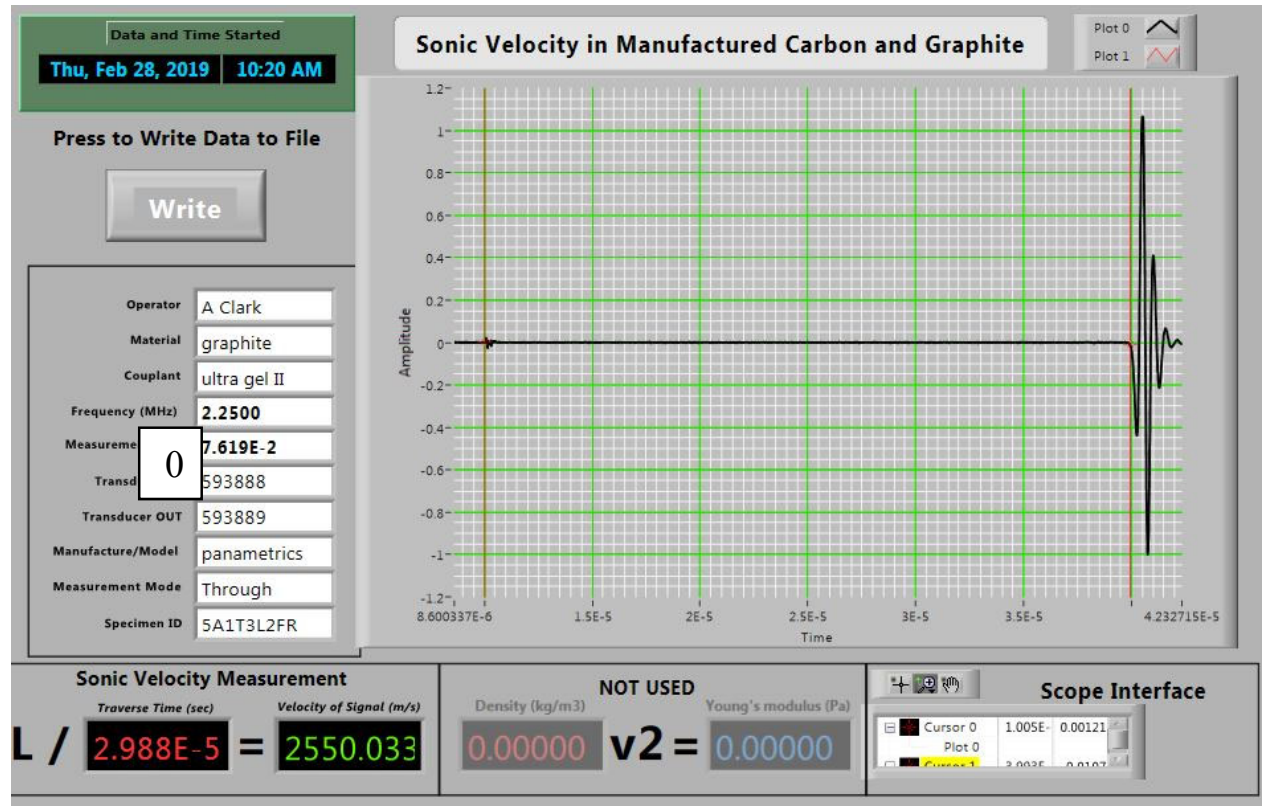

Figure 7. Typical longitudinal wave form (Time-of-flight $=2.988 \mathrm{E}-5 \mathrm{~s}$ ). 


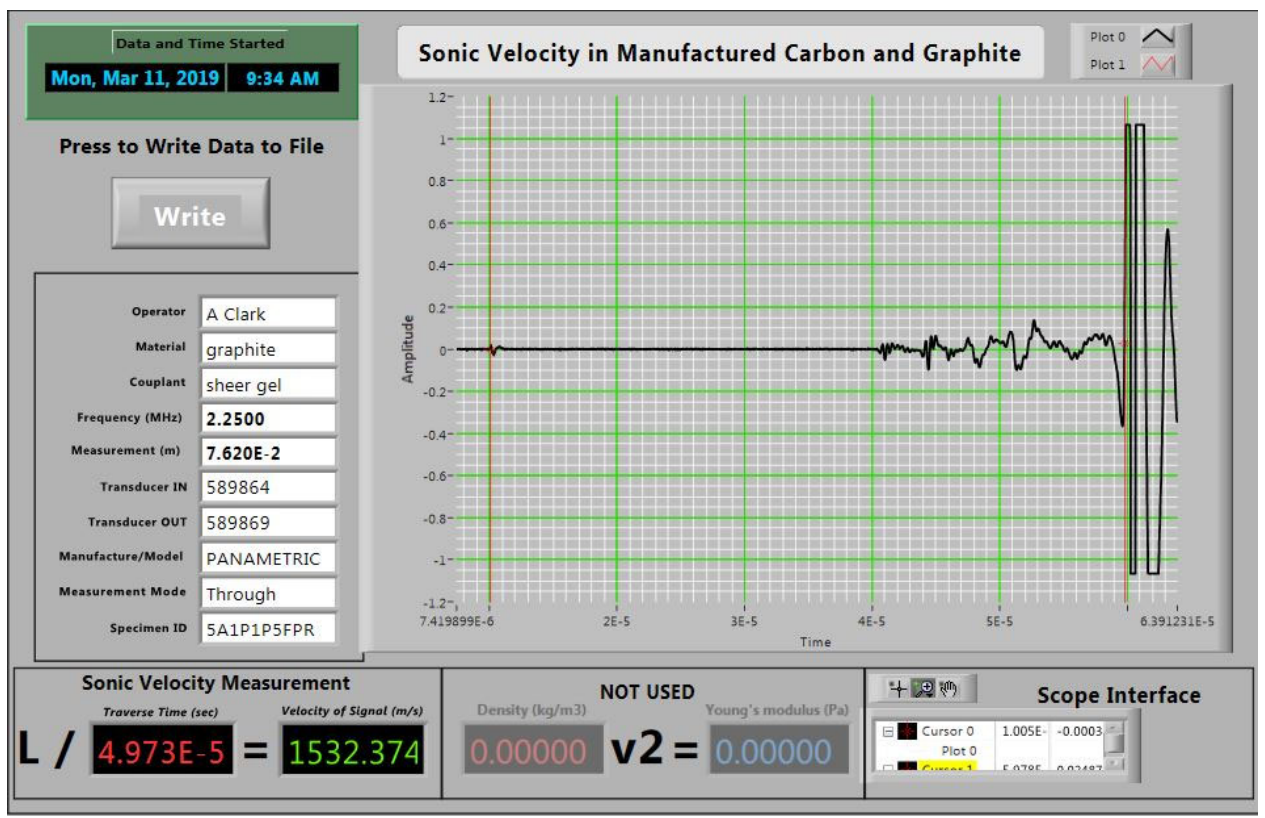

Figure 8. Typical shear wave form $($ Time-of-flight $=4.973 \mathrm{E}-5 \mathrm{~s})$.

After establishing the sonic velocity in each graphite sample (longitudinal and shear), the elastic constants $(\mathrm{G}, \mathrm{E}$, and $\mathrm{v})$ are determined as follows.

$\mathrm{G}$ is written as

$$
\mathrm{G}=\left(\mathrm{v}_{\mathrm{s}}\right)^{2} \cdot \rho
$$

where $\mathrm{G}$ is the shear modulus, $\rho$ is the specimen bulk density $\left(\mathrm{kg} / \mathrm{m}^{3}\right)$, and $\mathrm{V}_{\mathrm{s}}$ is the mean shear velocity [mean of $\mathrm{V}_{\mathrm{s}}\left(0^{\circ}\right)$ and $\mathrm{V}_{\mathrm{s}}\left(90^{\circ}\right)$ ].

$\mathrm{E}$ is similarly given by

$$
\mathrm{E}=\rho \cdot \mathrm{V}_{1}^{2} \cdot \mathrm{C}_{\mu},
$$

where $E$ is Young's modulus, $\rho$ is the specimen bulk density $\left(\mathrm{kg} / \mathrm{m}^{3}\right), \mathrm{V}_{1}$ is the mean longitudinal velocity, and $\mathrm{C}_{\mu}$ is the Poisson ratio correction factor.

$\mathrm{C}_{\mu}$ may be obtained from the following relationship:

$$
\mathrm{C}_{\mu}=(1+\mu)(1-2 \mu) /(1-\mu)
$$

ASTM C769 ${ }^{8}$ suggests a value for $\mu$ of 0.2 , in which case $C_{\mu}$ would be 0.9 .

However, in a departure from ASTM C769 and the experimental plan ${ }^{6}$, Poisson's ratio $(\mu)$ is calculated from

$$
\mu=\frac{1-\left[2\left(\frac{V_{S}}{V_{l}}\right)^{2}\right]}{2-\left[2\left(\frac{V_{S}}{V_{l}}\right)^{2}\right]},
$$


where $V_{s}$ and $V_{1}$ are the mean measured shear and longitudinal velocities $(\mathrm{m} / \mathrm{s})$ respectively.

A new ASTM standard is currently being developed for determination of the elastic constants using this method.

By combining Eqs. (2), (3), and (4) we may calculate a Poisson's corrected value for E.

\subsubsection{Fundamental Frequency}

The elastic constants E, G, and $\mu$ were also determined using the ff method in accordance with ASTM $\mathrm{C} 747^{9}$ using a GrindoSonic Mk5. The specimens were vibrated in the flexure mode. Each specimen was measured 10 times to generate a mean ff for calculation of the Young's modulus. Figure 9 shows the experimental apparatus including the tapping hammer and piezo-electric vibration detector.

During testing the test room air temperature and humidity were $22.2^{\circ} \mathrm{C}-25^{\circ} \mathrm{C}\left(72^{\circ} \mathrm{F}-77^{\circ} \mathrm{F}\right)$ and $49 \%-$ $54 \%$, respectively. The dynamic Young's modulus in pascals $(\mathrm{Pa})$ is given by ASTM $\mathrm{C} 747^{9}$ for a rectangular cross section beam as

$$
E=A_{R} \cdot M \cdot f^{2} / w
$$

where $w$ is the specimen width $(\mathrm{m}), M$ is the specimen mass $(\mathrm{g}), f$ is the $\mathrm{ff}(\mathrm{Hz})$, and $A_{R}$ is a function of the ratio of the dimension in the direction of vibration, $\mathrm{t}$, to the length, L. Values of $A_{R}$ are tabulated in ASTM C747. The flexural specimens in this work were tested in both orientations as illustrated in Figure 10. Test specimens were supported on thin, narrow parallel strips of foam mounting tape (Figure 11).

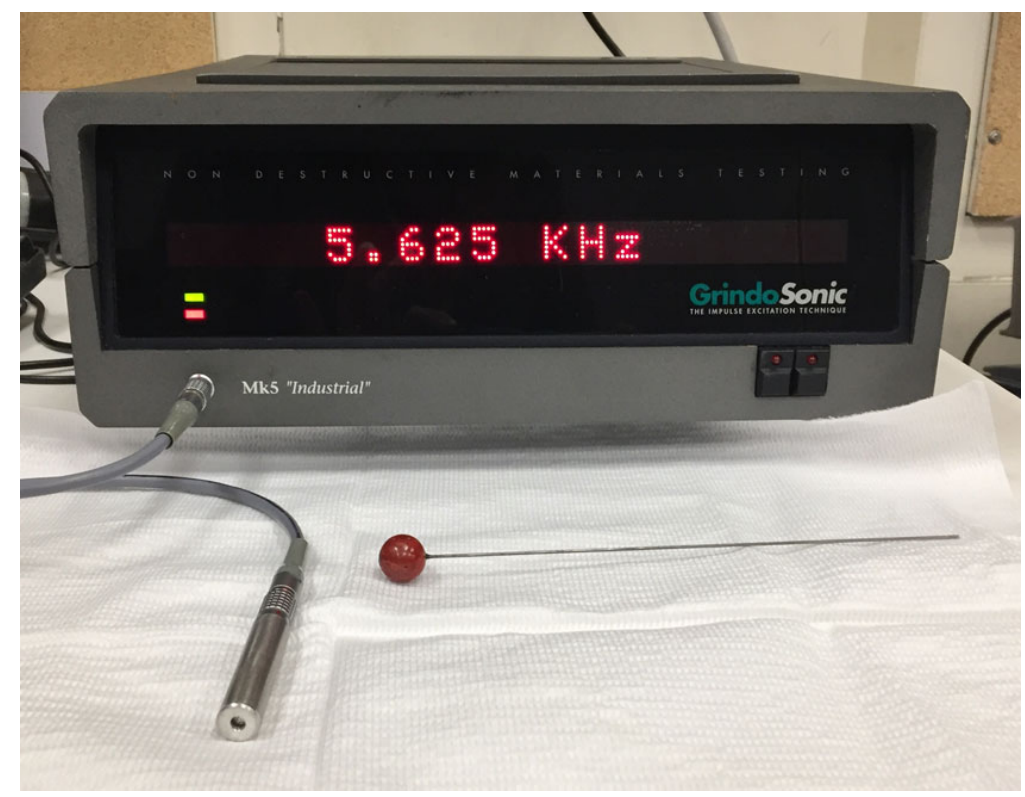

Figure 9. GrindoSonic Mk5 fundamental frequency modulus system. 


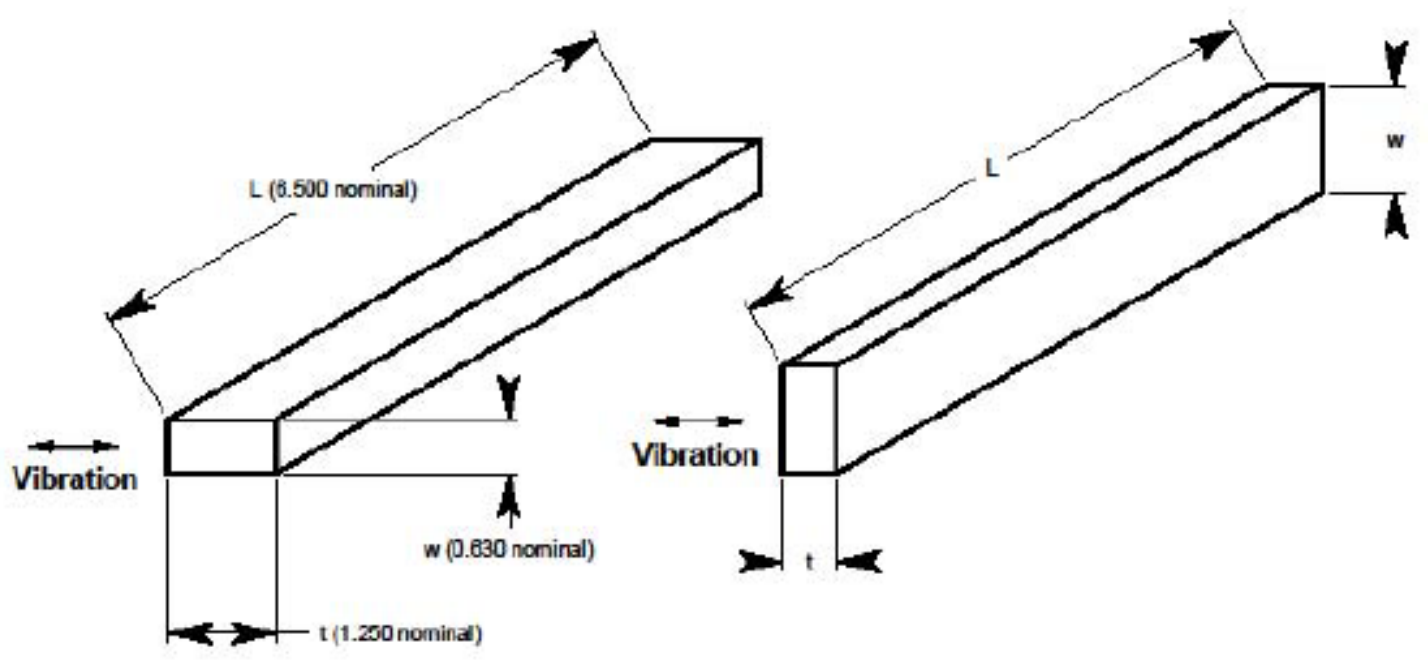

Figure 10. Specimen orientations for the flexural vibration mode defining the specimen length $(L)$, width $(W)$, and thickness $(t)$. Specimen dimensions in inches

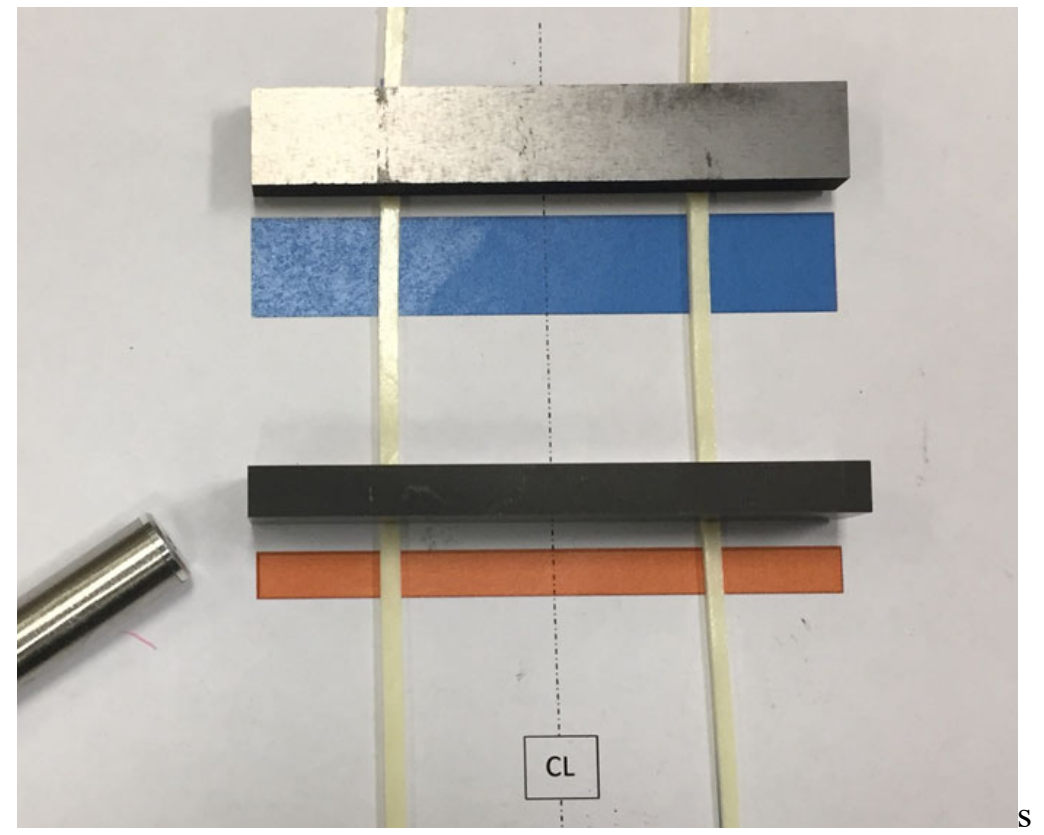

Figure 11. Flexural specimens in two orientations simply supported by narrow strips of foam mounting tape.

The ff method was also used to determine the modulus of rigidity (shear modulus). The shear modulus in pascals is given by ASTM C $747^{9}$ as

$$
G=4.000 \cdot R \cdot f^{2} \cdot L^{2} \cdot \rho,
$$

where $\rho$ is the density of the specimens $(\mathrm{kg} / \mathrm{m} 3)$ and $\mathrm{R}$ is as follows:

$$
R=\left[1+\left(a^{2} / b^{2}\right)\right] \div\left[4-2.52(b / a)+0.21(b / a)^{5}\right],
$$


where $a$ is the large dimension of the specimen cross section and $b$ is the small dimension of the cross section.

Determination of $\mathrm{G}$ requires that the specimen be vibrated in the torsion mode. To achieve this the specimen is supported on foam strips along the midpoint of its length and width (Figure 12).

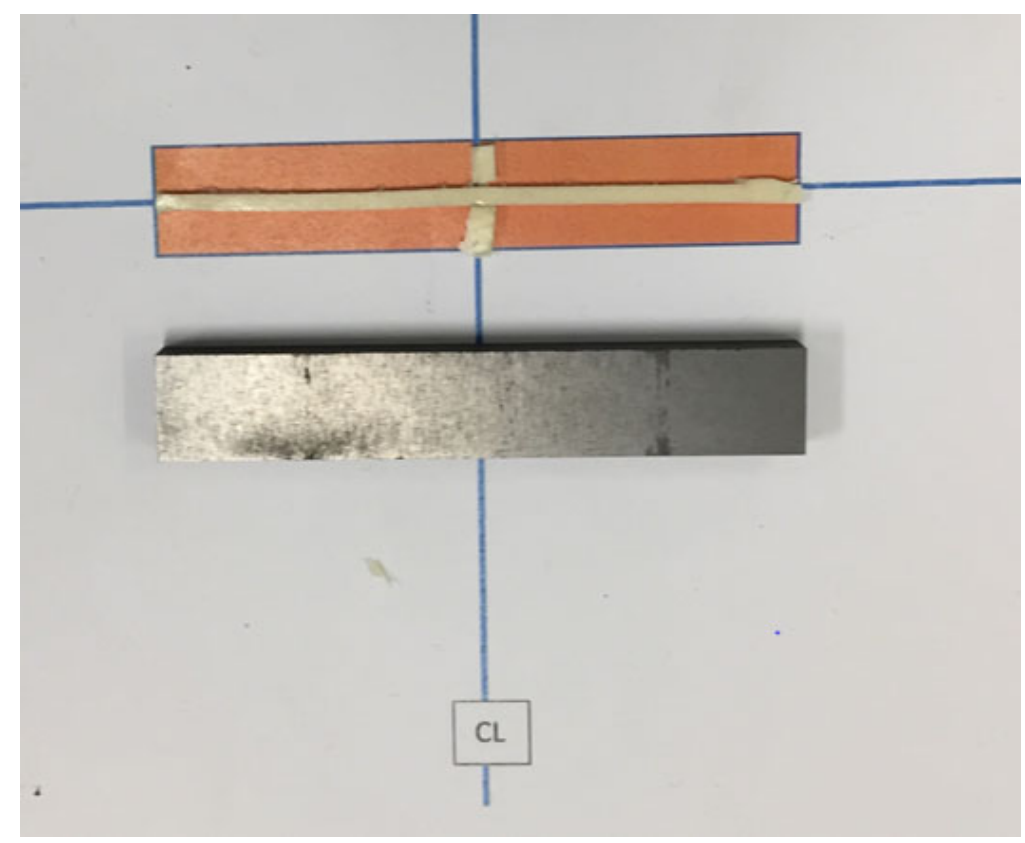

Figure 12. Specimen supported for the torsional vibration mode.

Given $\mathrm{E}$ and $\mathrm{G}, \mu$ may be calculated from the following relationship (for isotropic materials only):

$$
\mu=(E \div 2 G)-1
$$

\subsection{FLEXURE STRENGTH TESTING}

A drawing of the flexure specimen used is in Figure $2 .{ }^{6}$ Flexure specimens were cut from the billet end (slab 1) and the billet center (slab 5). ASTM C651-compliant specimens were used. ${ }^{10}$

Flexure tests were conducted according to ASTM C $651^{10}$ at a crosshead speed of $1.25 \mathrm{~mm} / \mathrm{minute}$ (0.049 in./minute) using an Instron tensile testing machine fitted with a $2 \mathrm{kN}$ (449.6 lbf) load cell. The load span was set to $19.05 \mathrm{~mm}$ (0.75 in.), and the support span was $57.15 \mathrm{~mm}$ (2.25 in.). The ASTM-compliant fixture is shown in Figure 13. The ambient temperature during testing was $22.8^{\circ} \mathrm{C}$ $\left(73^{\circ} \mathrm{F}\right)$, and the humidity was $55 \%$. Before testing the specimens were dried for $2 \mathrm{~h}$ at $120^{\circ} \mathrm{C}-150^{\circ} \mathrm{C}$ $\left(248^{\circ} \mathrm{F}-302^{\circ} \mathrm{F}\right)$. 


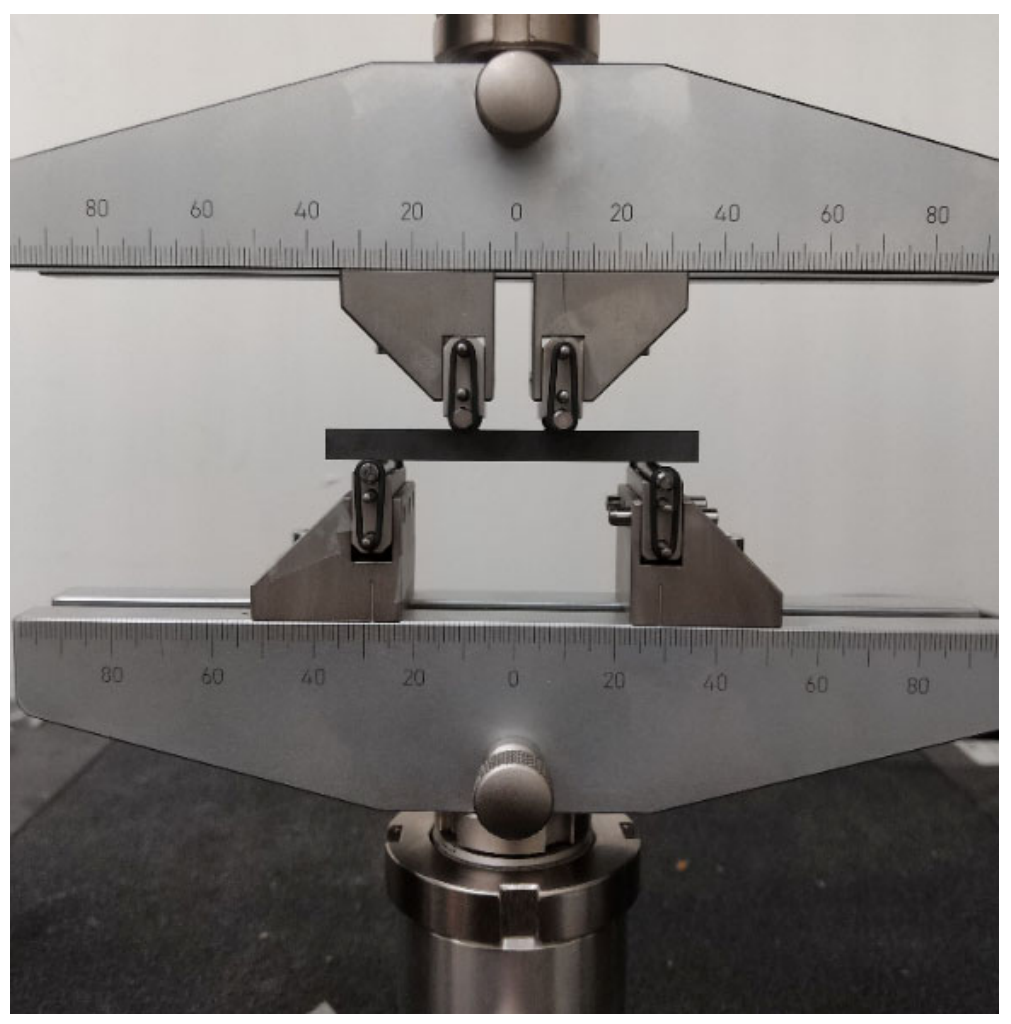

Figure 13. Typical flexure specimen under test in four-point loading.

The flexure strength is given by $\sigma_{\mathrm{f}}=\mathrm{P} \cdot \mathrm{L} / \mathrm{b} \cdot \mathrm{d}^{2}$,

where

$\sigma_{\mathrm{f}}=$ flexural strength, $\mathrm{MPa}$,

$\mathrm{P}=$ max applied load indicated by the test machine, $\mathrm{N}$,

$\mathrm{L}=$ support span length, $\mathrm{mm}$,

$\mathrm{b}=$ average width of specimen, $\mathrm{mm}$,

$\mathrm{d}=$ average thickness of the specimen, $\mathrm{mm}$.

\section{RESULTS AND DISCUSSION}

\subsection{BULK DENSITY}

The specimen bulk densities are given in Table A.1 (Appendix A). The bulk density subpopulations, i.e., sorted by filler orientation (WG or AG, Table A.2, Appendix A) or in-billet location (slab 1, end; or slab 5, center, Table A.3, Appendix A) were t tested to ensure they could be combined. The outcome of the $\mathrm{t}$ testing is given in Table 4 .

In each case the subpopulations were assumed to have identical means, i.e., the null hypothesis was the mean of group $1=$ the mean of group 2. Statistical $t$ testing found no evidence to reject the null hypothesis, and thus the entire population was used to establish the mean density of $1.819 \mathrm{~g} / \mathrm{cm}^{3}$ (standard deviation $=0.0037$ ). This value is very slightly larger than previously reported for the grade 2114 compressive strength population, ${ }^{1}$ but a specimen size effect of this nature is entirely consistent with data in the literature. ${ }^{11,12}$ A density of $1.8098 \mathrm{~g} / \mathrm{cm}^{3}$ for grade 2114 billet A20570 was obtained at Idaho 
National Laboratory (INL), which is less than that observed here. Mersen ${ }^{5}$ reported a density of 1.82 $\mathrm{g} / \mathrm{cm}^{3}$ for grade 2114 , which is in good agreement with the value reported here.

Table 4. Outcome of $t$ testing of the $\mathbf{2 1 1 4}$ graphite bulk densities measured on flexure strength specimens

\begin{tabular}{|c|c|c|c|c|c|c|c|c|}
\hline \multirow{2}{*}{$\begin{array}{l}\text { Population } \\
\text { description }\end{array}$} & \multirow[t]{2}{*}{$\mathbf{n}$} & \multirow{2}{*}{$\begin{array}{l}\text { Mean } \\
\text { kg.m } \mathrm{m}^{-3}\end{array}$} & \multirow{2}{*}{$\begin{array}{l}\text { St. } \\
\text { Dev. }\end{array}$} & \multicolumn{2}{|c|}{$\begin{array}{l}95 \% \text { confidence interval } \\
\text { on difference of means }\end{array}$} & \multirow{2}{*}{$\begin{array}{l}\text { Calculated } \\
\text { P value }\end{array}$} & \multirow{2}{*}{$\begin{array}{l}\text { Terminology } \\
\text { (per Table 1) }\end{array}$} & \multirow{2}{*}{$\begin{array}{c}\text { Null } \\
\text { hypothesis } \\
\text { verdict }\end{array}$} \\
\hline & & & & Min & Max & & & \\
\hline $\mathrm{AG}$ & 36 & 1819.47 & 4.24 & \multirow{2}{*}{-1.3798} & \multirow{2}{*}{2.1598} & \multirow{2}{*}{0.6616} & \multirow{2}{*}{ Not significant } & \multirow{2}{*}{$\begin{array}{c}\text { Not } \\
\text { rejected }\end{array}$} \\
\hline WG & 36 & 1819.80 & 3.22 & & & & & \\
\hline PERIPHERY & 48 & 1819.53 & 4.03 & \multirow{2}{*}{1.1011} & \multirow{2}{*}{2.6411} & \multirow{2}{*}{0.4146} & \multirow{2}{*}{ Not significant } & \multirow{2}{*}{$\begin{array}{c}\text { Not } \\
\text { rejected }\end{array}$} \\
\hline CENTER & 24 & 1818.76 & 3.11 & & & & & \\
\hline
\end{tabular}

Acronyms and abbreviations: St. Dev. = standard deviation, $\mathrm{AG}=$ against the grain, $\mathrm{WG}=$ with the grain, PERIPHERY $=$ slab1 (end), and CENTER = slab 5.

\subsection{ELASTIC CONSTANTS}

\subsubsection{Fundamental Frequency}

\subsubsection{Young's Modulus}

The method of the ff of vibration was used with the graphite bars in two orientations per the ASTM C747. ${ }^{9}$ The test data are given in Table A.4 (Appendix A). The two populations gave slightly different mean Young's moduli despite being calculated using appropriate geometric constants (Sect. 2.3.2.). Table 5 gives the population statistics and t testing outcome for the assumed null hypothesis of mean $\bar{\chi}_{\text {Eupright }}=$ $\bar{\chi}_{\text {Eflat }}$. Based on the $t$ testing outcome, the null hypothesis is rejected, and it is assumed that the two means are different. The ASTM standard for four-point loading ${ }^{10}$ has the beam in a "flat" orientation for testing. Consequently, the flat geometry modulus population was selected here for further interrogation and is given in Table A.5 (Appendix A).

Table 5. Population statistics and outcome of $t$ testing of the 2114 graphite Young's moduli (by fundamental frequency method) measured on compressive strength specimens

\begin{tabular}{|c|c|c|c|c|c|c|c|c|}
\hline \multirow[t]{2}{*}{$\begin{array}{l}\text { Population } \\
\text { description }\end{array}$} & \multirow[t]{2}{*}{$\mathbf{n}$} & \multirow[t]{2}{*}{$\begin{array}{c}\text { Mean } \\
\text { GPa }\end{array}$} & \multirow[t]{2}{*}{$\begin{array}{l}\text { St. } \\
\text { Dev. }\end{array}$} & \multicolumn{2}{|c|}{$\begin{array}{c}95 \% \text { confidence } \\
\text { interval on difference } \\
\text { of means }\end{array}$} & \multirow[t]{2}{*}{$\begin{array}{l}\text { Calculated } \\
\text { P value }\end{array}$} & \multirow[t]{2}{*}{$\begin{array}{l}\text { Terminology } \\
\text { (per Table 1) }\end{array}$} & \multirow[t]{2}{*}{$\begin{array}{c}\text { Null } \\
\text { hypothesis } \\
\text { verdict }\end{array}$} \\
\hline & & & & Min & Max & & & \\
\hline Upright & 72 & 10.21 & 0.35 & \multirow{2}{*}{0.063015} & \multirow{2}{*}{0.288985} & \multirow{2}{*}{0.0025} & \multirow{2}{*}{$\begin{array}{c}\text { Very } \\
\text { significant }\end{array}$} & \multirow{2}{*}{ Rejected } \\
\hline Flat & 72 & 10.03 & 0.33 & & & & & \\
\hline
\end{tabular}

St. Dev. = standard deviation.

The flat geometry population was $\mathrm{t}$ tested; the null hypothesis was $\bar{\chi}_{\mathrm{E} \text { (flat)AG }}=\bar{\chi}_{\mathrm{E} \text { (flat)WG }}$. The outcome of the $t$ test is in Table 6 . The difference between the two means was found to be very significant and the null hypothesis was rejected. Examination of Table 6 shows that the graphite is stiffer in the WG direction than in the AG direction, although the difference is small. This difference is expected and explained by the preferred orientation of the filler particles during forming and the grain/crystal bond anisotropy (covalent bonding in-plane, van-der-Waals bonds between planes). 
Table 6. Population statistics and outcome of t testing of the 2114 graphite Young's moduli (by fundamental frequency method) measured on flexural strength specimens in the flat orientation

\begin{tabular}{|c|c|c|c|c|c|c|c|c|}
\hline \multirow[t]{2}{*}{$\begin{array}{l}\text { Population } \\
\text { description }\end{array}$} & \multirow[t]{2}{*}{$\mathbf{n}$} & \multirow[t]{2}{*}{$\begin{array}{l}\text { Mean } \\
\text { GPa }\end{array}$} & \multirow[t]{2}{*}{$\begin{array}{l}\text { St. } \\
\text { Dev. }\end{array}$} & \multicolumn{2}{|c|}{$\begin{array}{c}95 \% \text { confidence } \\
\text { interval on difference } \\
\text { of means }\end{array}$} & \multirow[t]{2}{*}{$\begin{array}{c}\text { Calculated } \\
\text { P value }\end{array}$} & \multirow[t]{2}{*}{$\begin{array}{l}\text { Terminology } \\
\text { (per Table 1) }\end{array}$} & \multirow{2}{*}{$\begin{array}{l}\text { Null } \\
\text { hypothesis } \\
\text { verdict }\end{array}$} \\
\hline & & & & Min & Max & & & \\
\hline Flat AG & 36 & 9.92 & 0.31 & \multirow{2}{*}{-0.3781} & \multirow{2}{*}{-0.0819} & \multirow{2}{*}{0.0028} & \multirow{2}{*}{$\begin{array}{c}\text { Very } \\
\text { significant }\end{array}$} & \multirow{2}{*}{ Rejected } \\
\hline Flat WG & 36 & 10.15 & 0.32 & & & & & \\
\hline
\end{tabular}

Acronyms and abbreviations: St. Dev. = standard deviation, $\mathrm{AG}=$ against the grain, and $\mathrm{WG}=$ with the grain.

To investigate possible in-billet property variations the moduli (ff method) for the billet end (slab 1) was compared to the billet center (slab 5). Because we have shown that $\mathrm{E}_{\text {flat }} \neq \mathrm{E}_{\text {upright }}$ and $\mathrm{E}(\mathrm{WG}) \neq \mathrm{E}(\mathrm{AG})$, the comparison was made using only the flat geometry WG data.

Only the experimental data for the flat orientation WG samples are reported in Table A.6 (Appendix A), and the outcome of $t$ testing is given in Table 7.

This outcome (Table 7) suggests there is no anisotropy in the Young's moduli data. However, a similar $\mathrm{t}$ test of the $\mathrm{E}_{\text {flat }} \mathrm{AG}$ data (Table A.7, Appendix A), testing the null hypothesis that $\bar{\chi}_{F L A T}($ center $) \boldsymbol{A G}=$ $\bar{\chi}_{F L A T}(e n d) \boldsymbol{A G}$ showed the difference in the two means to be extremely statistically significant and the null hypothesis was rejected (Table 8).

Table 7. Population statistics and outcome of $t$ testing of the 2114 graphite Young's moduli (by fundamental frequency method) measured on flexural strength specimens in the flat orientation sorted by grain orientation (WG) and in-billet position

\begin{tabular}{|c|c|c|c|c|c|c|c|c|}
\hline \multirow[t]{2}{*}{$\begin{array}{l}\text { Population } \\
\text { description }\end{array}$} & \multirow[t]{2}{*}{$\mathbf{n}$} & \multirow[t]{2}{*}{$\begin{array}{c}\text { Mean } \\
\text { GPa }\end{array}$} & \multirow[t]{2}{*}{$\begin{array}{c}\text { St. } \\
\text { Dev. }\end{array}$} & \multicolumn{2}{|c|}{$\begin{array}{c}95 \% \text { confidence } \\
\text { interval on difference } \\
\text { of means }\end{array}$} & \multirow[t]{2}{*}{$\begin{array}{c}\text { Calculated } \\
\text { P value }\end{array}$} & \multirow[t]{2}{*}{$\begin{array}{l}\text { Terminology } \\
\text { (per Table 1) }\end{array}$} & \multirow[t]{2}{*}{$\begin{array}{c}\text { Null } \\
\text { hypothesis } \\
\text { verdict }\end{array}$} \\
\hline & & & & Min & Max & & & \\
\hline Flat $\mathrm{WG}_{\text {End }}$ & 24 & 10.09 & 0.37 & \multirow{2}{*}{-0.3882} & \multirow{2}{*}{0.0682} & \multirow{2}{*}{0.1633} & \multirow{2}{*}{$\begin{array}{l}\text { Not } \\
\text { statistically } \\
\text { significant }\end{array}$} & \multirow{2}{*}{ Not rejected } \\
\hline Flat $W_{\text {Center }}$ & 12 & 10.25 & 0.16 & & & & & \\
\hline
\end{tabular}

Acronyms and abbreviations: St. Dev. = standard deviation and $\mathrm{WG}=$ with the grain.

Table 8. Population statistics and outcome of $t$ testing of the 2114 graphite Young's moduli (by fundamental frequency method) measured on flexural strength specimens in the flat orientation sorted by grain orientation (AG) and in-billet position

\begin{tabular}{|c|c|c|c|c|c|c|c|c|}
\hline \multirow[t]{2}{*}{$\begin{array}{l}\text { Population } \\
\text { description }\end{array}$} & \multirow[t]{2}{*}{$\mathbf{n}$} & \multirow[t]{2}{*}{$\begin{array}{c}\text { Mean } \\
\text { GPa }\end{array}$} & \multirow[t]{2}{*}{$\begin{array}{l}\text { St. } \\
\text { Dev. }\end{array}$} & \multicolumn{2}{|c|}{$\begin{array}{c}95 \% \text { confidence } \\
\text { interval on difference } \\
\text { of means }\end{array}$} & \multirow[t]{2}{*}{$\begin{array}{l}\text { Calculated } \\
\text { P value }\end{array}$} & \multirow[t]{2}{*}{$\begin{array}{l}\text { Terminology } \\
\text { (per Table 1) }\end{array}$} & \multirow[t]{2}{*}{$\begin{array}{c}\text { Null } \\
\text { hypothesis } \\
\text { verdict }\end{array}$} \\
\hline & & & & Min & Max & & & \\
\hline Flat $\mathrm{AG}_{\text {End }}$ & 24 & 9.81 & 0.29 & \multirow{2}{*}{-0.5317} & \multirow{2}{*}{-0.1483} & \multirow{2}{*}{0.001} & \multirow{2}{*}{$\begin{array}{l}\text { Extremely } \\
\text { statistically } \\
\text { significant }\end{array}$} & \multirow{2}{*}{ Rejected } \\
\hline Flat $\mathrm{AG}_{\text {Center }}$ & 12 & 10.15 & 0.21 & & & & & \\
\hline
\end{tabular}

Acronyms and abbreviations: St. Dev. = standard deviation and $\mathrm{AG}=$ against the grain .

Similar $\mathrm{t}$ tests of the data from the upright orientation, i.e., the null hypotheses $\bar{\chi}_{U P R I G H T}($ end $) A G=$ $\bar{\chi}_{U P R I G H T}$ (center)AG and $\bar{\chi}_{U P R I G H T}($ end $) W G=\bar{\chi}_{U P R I G H T}$ (center) $W G$ found the same thing, i.e., 
comparing end to center data, WG data suggest isotropy, but the AG data suggest slight anisotropy. On balance, grade 2114 is not totally isotropic, but the variation is extremely small.

\subsubsection{Shear Modulus}

The ff of vibration in the torsional mode allows the calculation of the shear modulus (modulus of rigidity). The calculated values of $\mathrm{G}$ are in Appendix A, Table A.8 (sorted by grain orientation). To determine whether there was an effect of grain orientation $(\mathrm{AG} / \mathrm{WG})$ on shear modulus, the null hypothesis $\bar{\chi}_{\mathrm{G}_{A G}}=\bar{\chi}_{\mathrm{E}_{W G}}$ was $\mathrm{t}$ tested. The outcome of the $\mathrm{t}$ test is given in Table 9 .

Table 9. Population statistics and outcome of testing of the 2114 graphite shear moduli (by fundamental frequency method) measured on flexural strength specimens in the torsional mode

\begin{tabular}{|c|c|c|c|c|c|c|c|c|}
\hline \multirow[t]{2}{*}{$\begin{array}{l}\text { Population } \\
\text { description }\end{array}$} & \multirow[t]{2}{*}{$\mathbf{n}$} & \multirow[t]{2}{*}{$\begin{array}{c}\text { Mean } \\
\text { GPa }\end{array}$} & \multirow[t]{2}{*}{$\begin{array}{l}\text { St. } \\
\text { Dev. }\end{array}$} & \multicolumn{2}{|c|}{$\begin{array}{c}95 \% \text { confidence } \\
\text { interval on difference } \\
\text { of means }\end{array}$} & \multirow[t]{2}{*}{$\begin{array}{l}\text { Calculated } \\
\text { P value }\end{array}$} & \multirow[t]{2}{*}{$\begin{array}{l}\text { Terminology } \\
\text { (per Table 1) }\end{array}$} & \multirow{2}{*}{$\begin{array}{c}\text { Null } \\
\text { hypothesis } \\
\text { verdict }\end{array}$} \\
\hline & & & & Min & Max & & & \\
\hline $\mathrm{G}_{\mathrm{AG}}$ & 36 & 4.22 & 0.08 & \multirow{2}{*}{-0.0453} & \multirow{2}{*}{0.0253} & \multirow{2}{*}{0.5743} & \multirow{2}{*}{$\begin{array}{l}\text { Not } \\
\text { statistically } \\
\text { significant }\end{array}$} & \multirow{2}{*}{ Not rejected } \\
\hline $\mathrm{G}_{\mathrm{WG}}$ & 36 & 4.23 & 0.07 & & & & & \\
\hline
\end{tabular}

Acronyms and abbreviations: St. Dev. = standard deviation, $\mathrm{G}_{\mathrm{AG}}=$ shear modulus measured against the grain, and $\mathrm{G}_{\mathrm{WG}}=$ shear modulus measured with the grain.

Based on the outcome of $t$ testing the null hypothesis was not rejected, and it was assumed grain orientation had no effect on the shear modulus. This is reasonable as both orientations would be predominantly shearing along the crystallographic basal planes. Combining the populations gives a mean shear modulus of $4.228 \mathrm{GPa}$ (standard deviation $=0.073 \mathrm{GPa}$ ).

To establish whether the shear modulus varied from end to center of the billet, the data in Table A.9 was $t$ tested to establish any difference. The null hypothesis was taken as $\bar{\chi}_{G_{\text {end }}}=\bar{\chi}_{G_{c e n t e r}}$, and based on the test outcome (Table 10), the null hypothesis was rejected, and it was assumed the grade 2114 graphite varied slightly along the length of the billet.

The ASTM standard specification for nuclear graphite ${ }^{13}$ gives the maximum permissible isotropy ratio (based on the coefficient of thermal expansion) for an isotropic nuclear graphite to be 1.1. Although $\mathrm{E}$ and $\mathrm{G}$ isotropy ratios are not addressed in the standard specification, ${ }^{13}$ the variations reported here are much less than $10 \%$.

Table 10. Population statistics and outcome of t testing of the 2114 graphite shear moduli (by fundamental frequency method) measured on flexural strength specimens in the torsional mode for effect of in-billet location

\begin{tabular}{|c|c|c|c|c|c|c|c|c|}
\hline \multirow[t]{2}{*}{$\begin{array}{l}\text { Population } \\
\text { description }\end{array}$} & \multirow[t]{2}{*}{$\mathbf{n}$} & \multirow[t]{2}{*}{$\begin{array}{c}\text { Mean } \\
\text { GPa }\end{array}$} & \multirow[t]{2}{*}{$\begin{array}{l}\text { St. } \\
\text { Dev. }\end{array}$} & \multicolumn{2}{|c|}{$\begin{array}{c}95 \% \text { confidence } \\
\text { interval on difference } \\
\text { of means }\end{array}$} & \multirow[t]{2}{*}{$\begin{array}{c}\text { Calculated } \\
\text { P value }\end{array}$} & \multirow[t]{2}{*}{$\begin{array}{l}\text { Terminology } \\
\text { (per Table 1) }\end{array}$} & \multirow{2}{*}{$\begin{array}{c}\text { Null } \\
\text { hypothesis } \\
\text { verdict }\end{array}$} \\
\hline & & & & Min & Max & & & \\
\hline $\mathrm{G}_{\text {end }}$ & 48 & 4.21 & 0.08 & \multirow[b]{2}{*}{-0.0846} & \multirow[b]{2}{*}{0.0154} & \multirow[b]{2}{*}{0.0053} & \multirow{2}{*}{$\begin{array}{c}\text { very } \\
\text { statistically } \\
\text { significant }\end{array}$} & \multirow[b]{2}{*}{ Rejected } \\
\hline $\mathrm{G}_{\text {center }}$ & 24 & 4.26 & 0.04 & & & & & \\
\hline
\end{tabular}

Acronyms and abbreviations: St. Dev. = standard deviation, $\mathrm{G}_{\mathrm{end}}=$ shear modulus at the end of the billet, and $\mathrm{G}_{\mathrm{center}}=$ shear modulus at the center of the billet. 


\subsubsection{Poisson's Ratio}

The material's Poisson's ratio may be calculated knowing the Young's and shear moduli [Eq. (7)]. Calculated Poisson's ratio values (for $\mu$ calculated from data for FLAT and UPRIGHT oriented beams) are given in Table A.10 of Appendix A. The population means were $t$ tested to verify the null hypothesis $\bar{\chi}_{\mu U P R I G H T}=\bar{\chi}_{\mu_{F L A T}}$. The outcome of the t testing is in Table 11 . The null hypothesis was rejected, and the difference in the means was extremely statistically significant.

Table 11. Population statistics and outcome of $t$ testing of the 2114 graphite Poisson's ratio (by fundamental frequency method) measured on compressive strength specimens

\begin{tabular}{|c|c|c|c|c|c|c|c|c|}
\hline \multirow[t]{2}{*}{$\begin{array}{l}\text { Population } \\
\text { description }\end{array}$} & \multirow[t]{2}{*}{$\mathbf{n}$} & \multirow[t]{2}{*}{ Mean } & \multirow[t]{2}{*}{$\begin{array}{l}\text { St. } \\
\text { Dev. }\end{array}$} & \multicolumn{2}{|c|}{$\begin{array}{c}95 \% \text { confidence } \\
\text { interval on difference } \\
\text { of means }\end{array}$} & \multirow[t]{2}{*}{$\begin{array}{l}\text { Calculated } \\
\text { P value }\end{array}$} & \multirow[t]{2}{*}{$\begin{array}{l}\text { Terminology } \\
\text { (per Table 1) }\end{array}$} & \multirow{2}{*}{$\begin{array}{c}\text { Null } \\
\text { hypothesis } \\
\text { verdict }\end{array}$} \\
\hline & & & & Min & Max & & & \\
\hline$\mu_{\text {Upright }}$ & 72 & 0.21 & 0.03 & \multirow[b]{2}{*}{0.0101} & \multirow[b]{2}{*}{0.0299} & \multirow[b]{2}{*}{0.0001} & \multirow{2}{*}{$\begin{array}{l}\text { Extremely } \\
\text { statistically } \\
\text { significant }\end{array}$} & \multirow[b]{2}{*}{ Rejected } \\
\hline$\mu_{\text {Flat }}$ & 72 & 0.19 & 0.03 & & & & & \\
\hline
\end{tabular}

Acronyms and abbreviations: St. Dev. $=$ standard deviation, $\mu$ Upright $=$ Poisson's ratio measured in an upright orientation, and $\mu_{\text {Flat }}=$ Poisson's ratio measured from a flat orientation.

Such an outcome is not surprising as the reported $\mu$ value is calculated from the Young's moduli data (which also shows a similar specimen geometry dependency).

The ASTM standard for four-point loading ${ }^{10}$ has the beam in a "flat" orientation for testing. Consequently, the "flat" geometry Poisson's ratio population was selected for further interrogation (the test data are given in Appendix A, Table A.11). The materials anisotropy was checked, the null hypothesis was $\bar{\chi}_{\mu \text { (flat)AG }}=\bar{\chi}_{\mu(\text { flat }) \mathrm{WG}}$. The outcome of the $\mathrm{t}$ test is given in Table 12 and suggests the means are dissimilar, i.e., $\bar{\chi}_{\mu(\text { flat }) \mathrm{AG}} \neq \bar{\chi}_{\mu(\mathrm{flat}) \mathrm{WG}}$.

Table 12. Population statistics and outcome of $t$ testing of the 2114 graphite Poisson's ratio (by fundamental frequency method) measured on flexural strength specimens in the flat orientation, AG against WG

\begin{tabular}{|c|c|c|c|c|c|c|c|c|}
\hline \multirow{2}{*}{$\begin{array}{c}\text { Population } \\
\text { description }\end{array}$} & $\mathbf{n}$ & Mean & \multirow{2}{*}{$\begin{array}{c}\text { St. } \\
\text { Dev. }\end{array}$} & \multicolumn{2}{|c|}{$\begin{array}{c}\text { 95\% confidence } \\
\text { interval on difference } \\
\text { of means }\end{array}$} & $\begin{array}{c}\text { Calculated } \\
\text { P value }\end{array}$ & $\begin{array}{c}\text { Terminology } \\
\text { (per Table 1) }\end{array}$ & $\begin{array}{c}\text { Null } \\
\text { hypothesis } \\
\text { verdict }\end{array}$ \\
\cline { 3 - 5 } & & & & Min & Max & & \multirow{2}{*}{$\begin{array}{c}\text { Extremely } \\
\text { statistically } \\
\text { significant }\end{array}$} & Rejected \\
\hline$\mu_{\mathrm{AG}}$ & 36 & 0.17 & 0.02 & \multirow{2}{*}{-0.0420} & -0.0180 & $<0.0001$ & \\
\hline
\end{tabular}

Acronyms and abbreviations: $\mathrm{AG}=$ against the grain, $\mathrm{WG}=$ with the grain, $\mathrm{St}$. Dev. $=$ standard deviation, $\mu_{\mathrm{AG}}=$ Poisson's ratio measured against the grain, and $\mu_{\mathrm{WG}}=$ Poisson's ratio measured with the grain.

Since $\bar{\chi}_{\mu \text { (flat)AG }} \neq \bar{\chi}_{\mu \text { (flat)WG }}$, only the WG Poisson's ratio subpopulation was used to assess differences due to in-billet location. The end and center subpopulations (Table A.12 in Appendix A) were t tested and the difference between the means was statistically significant (Table 13). 
Table 13. Population statistics and outcome of $t$ testing, WG only, of the 2114 graphite Poisson's ratio (by fundamental frequency method) measured on flexural strength specimens in the flat orientation for effect of position (end against center)

\begin{tabular}{|c|c|c|c|c|c|c|c|c|}
\hline \multirow[t]{2}{*}{$\begin{array}{l}\text { Population } \\
\text { description }\end{array}$} & \multirow[t]{2}{*}{$\mathbf{n}$} & \multirow[t]{2}{*}{ Mean } & \multirow[t]{2}{*}{$\begin{array}{l}\text { St. } \\
\text { Dev. }\end{array}$} & \multicolumn{2}{|c|}{$\begin{array}{c}95 \% \text { confidence } \\
\text { interval on difference } \\
\text { of means }\end{array}$} & \multirow[t]{2}{*}{$\begin{array}{l}\text { Calculated } \\
P \text { value }\end{array}$} & \multirow[t]{2}{*}{$\begin{array}{l}\text { Terminology } \\
\text { (per Table 1) }\end{array}$} & \multirow[t]{2}{*}{$\begin{array}{c}\text { Null } \\
\text { hypothesis } \\
\text { verdict }\end{array}$} \\
\hline & & & & Min & Max & & & \\
\hline$\mu_{\mathrm{WG}, \mathrm{END}}$ & 24 & 0.20 & 0.03 & \multirow{2}{*}{0.0018} & \multirow{2}{*}{0.0382} & \multirow{2}{*}{00322} & \multirow{2}{*}{$\begin{array}{l}\text { Statistically } \\
\text { significant }\end{array}$} & \multirow{2}{*}{ Rejected } \\
\hline$\mu_{\mathrm{WG}, \mathrm{CENTER}}$ & 12 & 0.18 & 0.01 & & & & & \\
\hline
\end{tabular}

Acronyms and abbreviations: $\mathrm{WG}=$ with the grain, St. Dev. = standard deviation, $\mu_{\mathrm{WG}, \mathrm{END}}=$ Poisson's ratio measured

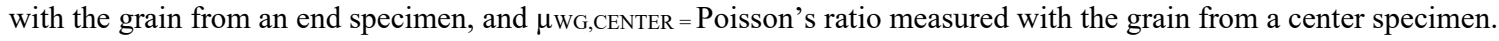

The trend in Poisson's ratio (flat specimens, WG orientation) suggests some variation from billet center to edge (Table 13). This result is contrary to that seen in the Young's modulus data (Table 7) but in agreement with the $\mathrm{G}$ data (Table 10). Thus, the observed variation is expected because $\mu$ is calculated from E and G [Eq. (7)]. However, the variation in Poisson's ratio is small, and thus the graphite is still considered to be isotropic as defined in ASTM D7219.

\subsubsection{Sonic Velocity}

The test geometry of the flexure strength beam allows determination of the elastic constants both by the ff of vibration $\left(\mathrm{ASTM} \mathrm{C} 747^{9}\right)$ and the sonic velocity or TOF $\left(\mathrm{ASTM} \mathrm{C} 769^{8}\right)$. Thus, we can compare the two methods for obtaining the elastic constants and look for any equivalence.

Table A.13 (Appendix A) gives the elastic constants derived from the sonic velocity (TOF) for the grade 2114 flexure bars. These were further sorted by grain orientation, with results reported in Table A.14 and Table A.15 of Appendix A. The AG and WG population mean and standard deviation are given in Table 14. The summary data in Table 14 show in each case the elastic constant is slightly greater in the WG specimen orientation. This inequality was $t$ tested, ${ }^{4}$ and the outcomes of $t$ testing are given in Table 15 (for G) on $\mu$, Table 16 (for $\mu$ ), and Table 17 (for E Eoisson's Corrected). In each case the null hypothesis was $\bar{\chi}_{A G}=\bar{\chi}_{W G}$.

Table 14. Sonic elastic constant's population statistics

\begin{tabular}{|c|c|c|c|c|c|c|}
\hline \multirow{4}{*}{ Population statistic } & \multicolumn{6}{|c|}{ Sonic Elastic Constants } \\
\hline & \multirow{2}{*}{\multicolumn{2}{|c|}{$\begin{array}{c}\text { Shear modulus } \\
\mathbf{G}=\rho v_{\mathrm{s}}^{2}\end{array}$}} & \multirow{2}{*}{\multicolumn{2}{|c|}{$\begin{array}{c}\text { Poisson's ratio } \\
\mu=\left(1-\left[2\left(v_{s} / v_{1}\right) 2\right]\right) / \\
\left(2-\left[2\left(v_{s} / v_{1}\right) 2\right]\right)\end{array}$}} & \multirow{2}{*}{\multicolumn{2}{|c|}{$\begin{array}{l}\begin{array}{l}\text { Poisson's corrected elastic modulus } \\
\mathrm{E}=\rho \mathrm{V}_{1}^{2} \cdot[(1+\mu)(1-2 \mu) /(1-\mu)]\end{array} \\
\mathrm{GPa}\end{array}$}} \\
\hline & & & & & & \\
\hline & AG & WG & AG & WG & AG & WG \\
\hline Mean & 4.25 & 4.27 & 0.19 & 0.20 & 10.13 & 10.26 \\
\hline Standard deviation & 0.08 & 0.09 & 0.01 & 0.01 & 0.24 & 0.26 \\
\hline Number in population & 36 & 36 & 36 & 36 & 36 & 36 \\
\hline
\end{tabular}

Acronyms and abbreviations: $\mathrm{AG}=$ against the grain and $\mathrm{WG}=$ with the grain. 
Table 15. Population statistics and outcome of $t$ testing for sonic shear moduli (G) data from testing in the with and against the grain directions (WG and AG)

\begin{tabular}{|c|c|c|c|c|c|c|c|c|}
\hline \multirow[t]{2}{*}{$\begin{array}{l}\text { Population } \\
\text { description }\end{array}$} & \multirow[t]{2}{*}{$\mathbf{n}$} & \multirow[t]{2}{*}{$\begin{array}{c}\text { Mean } \\
\text { GPa }\end{array}$} & \multirow[t]{2}{*}{$\begin{array}{l}\text { St. } \\
\text { Dev. }\end{array}$} & \multicolumn{2}{|c|}{$\begin{array}{c}95 \% \text { confidence } \\
\text { interval on difference } \\
\text { of means }\end{array}$} & \multirow[t]{2}{*}{$\begin{array}{l}\text { Calculated } \\
\text { P value }\end{array}$} & \multirow[t]{2}{*}{$\begin{array}{l}\text { Terminology } \\
\text { (per Table 1) }\end{array}$} & \multirow[t]{2}{*}{$\begin{array}{c}\text { Null } \\
\text { hypothesis } \\
\text { verdict }\end{array}$} \\
\hline & & & & Min & Max & & & \\
\hline $\mathrm{G}_{\mathrm{AG}}$ & 36 & 4.25 & 0.08 & \multirow{2}{*}{-0.060} & \multirow{2}{*}{0.020} & \multirow{2}{*}{0.3224} & \multirow{2}{*}{$\begin{array}{c}\text { Not } \\
\text { statistically } \\
\text { significant }\end{array}$} & \multirow{2}{*}{ Not rejected } \\
\hline $\mathrm{G}_{\mathrm{WG}}$ & 36 & 4.27 & 0.09 & & & & & \\
\hline
\end{tabular}

St. Dev. = standard deviation.

The result for $\mathrm{G}$ (Table 15) agrees with the $\mathrm{t}$ test performed previously for the $\mathrm{G}$ data from ff testing (Table 9). The null hypothesis cannot be rejected, and we have evidence that grain (filler) orientation does not affect the value of shear modulus, G. A similar comparison of Poisson's ratio, $\mu$, from the sonic velocity data (Table 16) and the ff method (Table 12) shows that for both methods the data suggest $\mu_{\mathrm{WG}} \neq$ $\mu_{\mathrm{AG}}$, indicating an effect of filler particle orientation on $\mu$.

Table 16. Population statistics and outcome of t testing for sonic Poisson's ratio $(\mu)$ data from testing in the with and against the grain directions (WG and AG)

\begin{tabular}{|c|c|c|c|c|c|c|c|c|}
\hline \multirow[t]{2}{*}{$\begin{array}{l}\text { Population } \\
\text { description }\end{array}$} & \multirow[t]{2}{*}{$\mathbf{n}$} & \multirow[t]{2}{*}{ Mean } & \multirow[t]{2}{*}{$\begin{array}{l}\text { St. } \\
\text { Dev. }\end{array}$} & \multicolumn{2}{|c|}{$\begin{array}{c}95 \% \text { confidence } \\
\text { interval on difference } \\
\text { of means }\end{array}$} & \multirow[t]{2}{*}{$\begin{array}{l}\text { Calculated } \\
\text { P value }\end{array}$} & \multirow[t]{2}{*}{$\begin{array}{l}\text { Terminology } \\
\text { (per Table 1) }\end{array}$} & \multirow[t]{2}{*}{$\begin{array}{c}\text { Null } \\
\text { hypothesis } \\
\text { verdict }\end{array}$} \\
\hline & & & & Min & Max & & & \\
\hline$\mu_{\mathrm{AG}}$ & 36 & 0.19 & 0.01 & \multirow[b]{2}{*}{0.0147} & \multirow[b]{2}{*}{0.0053} & \multirow[b]{2}{*}{$<0.0001$} & \multirow{2}{*}{$\begin{array}{l}\text { Extremely } \\
\text { statistically } \\
\text { significant }\end{array}$} & \multirow[b]{2}{*}{ Rejected } \\
\hline$\mu_{\mathrm{WG}}$ & 36 & 0.20 & 0.01 & & & & & \\
\hline
\end{tabular}

St. Dev. $=$ standard deviation.

The $t$ testing outcome for the corrected Young's modulus (Table 17) suggests that the null hypothesis is incorrect and should be rejected. Thus, the data suggest $\mathrm{E}_{\mathrm{AG}} \neq \mathrm{E}_{\mathrm{WG}}$. This is expected and reflects the slight texture that develops when the graphite is formed and the strong bond anisotropy of the single crystal. The observation that $\mathrm{E}_{\mathrm{AG}} \neq \mathrm{E}_{\mathrm{WG}}$ agrees with our previous data for Young's modulus from the ff method (Table 6).

Table 17. Population statistics and outcome of $t$ testing for sonic Young's moduli [ $\left.E_{(\text {Poisson's corrected })}\right]$ data from testing in the with and against the grain directions (WG and AG)

\begin{tabular}{|c|c|c|c|c|c|c|c|c|}
\hline \multirow[t]{2}{*}{$\begin{array}{l}\text { Population } \\
\text { description }\end{array}$} & \multirow[t]{2}{*}{$\mathbf{n}$} & \multirow[t]{2}{*}{$\begin{array}{c}\text { Mean } \\
\text { GPa }\end{array}$} & \multirow[t]{2}{*}{$\begin{array}{l}\text { St. } \\
\text { Dev. }\end{array}$} & \multicolumn{2}{|c|}{$\begin{array}{c}95 \% \text { confidence } \\
\text { interval on difference } \\
\text { of means }\end{array}$} & \multirow[t]{2}{*}{$\begin{array}{c}\text { Calculated } \\
\text { P value }\end{array}$} & \multirow[t]{2}{*}{$\begin{array}{l}\text { Terminology } \\
\text { (per Table 1) }\end{array}$} & \multirow{2}{*}{$\begin{array}{c}\text { Null } \\
\text { hypothesis } \\
\text { verdict }\end{array}$} \\
\hline & & & & Min & Max & & & \\
\hline $\mathrm{E}_{\mathrm{AG}}$ & 36 & 10.13 & 0.24 & \multirow{2}{*}{-0.2476} & \multirow{2}{*}{-0.0124} & \multirow{2}{*}{0.0308} & \multirow{2}{*}{$\begin{array}{c}\text { Statistically } \\
\text { significant }\end{array}$} & \multirow{2}{*}{ Rejected } \\
\hline $\mathrm{E}_{\mathrm{WG}}$ & 36 & 10.26 & 0.26 & & & & & \\
\hline
\end{tabular}

St. Dev. $=$ standard deviation.

Variations of properties with in-billet location were extensively assessed using the ff data set.

Consequently, only the sonic (TOF) Poisson's corrected Young's modulus data set was examined. Table A.16 and Table A.17 of Appendix A contain the sonic (TOF) Poisson's corrected E data for the AG and WG populations, sorted by in-billet position. Note the end-of-billet specimens have specimen numbers 
beginning with a numeral " 1 ," and center-of-billet specimens have numbers beginning with a numeral "5." For the purpose of t testing, the null hypothesis was taken as $\bar{\chi}_{E(\mu \text { corrected })} A G(E n d)=$ $\bar{\chi}_{E(\mu \text { corrected }} A G($ Center $)$ and $\bar{\chi}_{E(\mu \text { corrected })} W G(E n d)=\bar{\chi}_{E(\mu \text { corrected }} W G$ (Center). The outcomes of the $\mathrm{t}$ testing are reported in Table 18 and Table 19.

The results of $t$ testing were mixed: for the AG population the null hypothesis was rejected, and for the WG population the null hypothesis was not rejected. On balance the variation (if any) was less than 10\%, and thus the graphite should be considered isotropic as defined by ASTM D7219.

Table 18. Population statistics and outcome of $t$ testing for sonic Young's moduli (Poisson's corrected) data from testing in the against the grain direction (AG) sorted by in-billet position (End or Center)

\begin{tabular}{|c|c|c|c|c|c|c|c|c|}
\hline \multirow[t]{2}{*}{$\begin{array}{l}\text { Population } \\
\text { description }\end{array}$} & \multirow[t]{2}{*}{$\mathbf{n}$} & \multirow[t]{2}{*}{$\begin{array}{l}\text { Mean } \\
\text { GPa }\end{array}$} & \multirow[t]{2}{*}{$\begin{array}{l}\text { St. } \\
\text { Dev. }\end{array}$} & \multicolumn{2}{|c|}{$\begin{array}{c}95 \% \text { confidence } \\
\text { interval on difference } \\
\text { of means }\end{array}$} & \multirow[t]{2}{*}{$\begin{array}{c}\text { Calculated } \\
\text { P value }\end{array}$} & \multirow[t]{2}{*}{$\begin{array}{l}\text { Terminology } \\
\text { (per Table 1) }\end{array}$} & \multirow{2}{*}{$\begin{array}{l}\text { Null } \\
\text { hypothesis } \\
\text { verdict }\end{array}$} \\
\hline & & & & Min & Max & & & \\
\hline $\mathrm{E}_{\mathrm{AG}}($ End $)$ & 24 & 9.639 & 0.214 & \multirow[b]{2}{*}{-0.81569} & \multirow[b]{2}{*}{-0.52631} & \multirow[b]{2}{*}{$<0.0001$} & \multirow{2}{*}{$\begin{array}{l}\text { Extremely } \\
\text { statistically } \\
\text { significant }\end{array}$} & \multirow[b]{2}{*}{ Rejected } \\
\hline $\mathrm{E}_{\mathrm{AG}}($ Center $)$ & 12 & 10.31 & 0.172 & & & & & \\
\hline
\end{tabular}

Acronyms and abbreviations: St. Dev. = standard deviation and $\mathrm{E}_{\mathrm{AG}}=$ Poisson's corrected data for Young's moduli measured in the against the grain direction.

Table 19. Population statistics and outcome of $t$ testing for sonic Young's moduli (Poisson's corrected) data from testing in the with the grain direction (WG) sorted by in-billet position (End or Center)

\begin{tabular}{|c|c|c|c|c|c|c|c|c|}
\hline \multirow[t]{2}{*}{$\begin{array}{l}\text { Population } \\
\text { description }\end{array}$} & \multirow[t]{2}{*}{$\mathbf{n}$} & \multirow[t]{2}{*}{$\begin{array}{c}\text { Mean } \\
\text { GPa }\end{array}$} & \multirow[t]{2}{*}{$\begin{array}{l}\text { St. } \\
\text { Dev. }\end{array}$} & \multicolumn{2}{|c|}{$\begin{array}{c}95 \% \text { confidence } \\
\text { interval on difference } \\
\text { of means }\end{array}$} & \multirow[t]{2}{*}{$\begin{array}{c}\text { Calculated } \\
\text { P value }\end{array}$} & \multirow[t]{2}{*}{$\begin{array}{l}\text { Terminology } \\
\text { (per Table 1) }\end{array}$} & \multirow{2}{*}{$\begin{array}{c}\text { Null } \\
\text { hypothesis } \\
\text { verdict }\end{array}$} \\
\hline & & & & Min & Max & & & \\
\hline $\mathrm{E}_{\mathrm{WG}}($ End $)$ & 24 & 10.21 & 0.294 & \multirow{2}{*}{-0.32821} & \multirow[b]{2}{*}{0.02821} & \multirow[b]{2}{*}{0.0963} & \multirow{2}{*}{$\begin{array}{l}\text { Not } \\
\text { statistically } \\
\text { significant }\end{array}$} & \multirow[b]{2}{*}{ Not Rejected } \\
\hline $\mathrm{E}_{\mathrm{WG}}($ Center $)$ & 12 & 10.36 & 0.097 & & & & & \\
\hline
\end{tabular}

Acronyms and abbreviations: St. Dev. = standard deviation and EWG = Poisson's corrected data for Young's moduli measured in the with the grain direction.

Perhaps of greater interest are comparisons between ff data and the sonic velocity data. Table 20 shows the mean, standard deviation, and population size for the elastic constants obtained from the fundamental frequency method (ASTM C $747^{9}$ ) and the sonic velocity (TOF) method (ASTM C769 ${ }^{8}$ ). 
Table 20. Comparison of the elastic constants obtained from the fundamental frequency method (ASTM ${\mathrm{C} 747^{9}}^{\text {) }}$ and the sonic velocity (TOF) method (ASTM C7698)

\begin{tabular}{|c|c|c|c|c|}
\hline \multirow{4}{*}{ Property } & \multicolumn{3}{|c|}{$\begin{array}{c}\text { Fundamental Frequency } \\
\text { ASTM C747 }\end{array}$} & $\begin{array}{c}\text { Sonic Velocity (time-of- } \\
\text { flight) ASTM C769 }\end{array}$ \\
\cline { 2 - 5 } & \multicolumn{2}{|c|}{$\begin{array}{c}\text { Mean and Standard } \\
\text { Deviation (sample size) }\end{array}$} & $\begin{array}{c}\text { Mean and Standard } \\
\text { Deviation (sample size) }\end{array}$ \\
\hline Grain Orientation & AG & WG & AG & WG \\
\hline \multirow{2}{*}{ Shear Modulus $(G), G P a$} & 4.22 (TOR) & 4.23 (TOR) & 4.25 & 4.27 \\
\cline { 2 - 5 } & $0.08(36)$ & $0.07(36)$ & $0.08(36)$ & $0.09(36)$ \\
\hline \multirow{2}{*}{ Poisson's Ratio $(\mu)$} & 0.17 (FLAT) & $0.20($ FLAT) & 0.19 & 0.20 \\
\cline { 2 - 5 } & $0.02(36)$ & $0.03(36)$ & $0.01(36)$ & $0.01(36)$ \\
\hline \multirow{2}{*}{ Young's Modulus $(\mathrm{E}), \mathrm{GPa}$} & $9.92($ FLAT) & $10.15(\mathrm{FLAT})$ & 10.13 & 10.26 \\
\cline { 2 - 5 } & $0.31(36)$ & $0.32(36)$ & $0.23(36)$ & $0.26(36)$ \\
\hline
\end{tabular}

Acronyms and abbreviations: $\mathrm{TOF}=$ time-of-flight, $\mathrm{AG}=$ against the grain direction, $\mathrm{WG}=$ with the grain direction, and TOR $=$ torsional mode vibrations, and FLAT $=$ flat orientation.

The two methods appear to yield similar values for the elastic constants as would be expected for an isotropic, fine-grain material such as grade 2114 graphite [note the sonic velocity (TOF) value of $E$ is Poisson's corrected]. There is some (slight) anisotropy, the WG values exceeding the AG values for both test methods. To properly compare the two test methods a series of statistical significance tests were conducted, setting the null hypothesis to $\bar{\chi}_{A G}(G)(f f)=\bar{\chi}_{A G}(G)(T O F)$ or $\bar{\chi}_{W G}(G)(f f)=$ $\bar{\chi}_{W G}(G)(T O F)$ (Table 21 and Table 22). Similarly, for the other elastic constants ( $\mu$ and E) the populations tested always were of the same grain orientation. Note also that the ff values were for the flat specimen test geometry. The outcomes of $t$ testing for $\mathrm{G}$ were mixed, as were those for $\mu$ (Table 23 and Table 24) and $\mathrm{E}_{(\mu \mathrm{corrected})}($ Table 25 and Table 26).

Shear Modulus

Table 21. Population statistics and outcome of $t$ testing for against the grain (AG) shear modulus (G) data by sonic velocity (TOF) method and fundamental frequency (ff) method

\begin{tabular}{|c|c|c|c|c|c|c|c|c|}
\hline \multirow[t]{2}{*}{$\begin{array}{l}\text { Population } \\
\text { description }\end{array}$} & \multirow[t]{2}{*}{$\mathbf{n}$} & \multirow[t]{2}{*}{$\begin{array}{c}\text { Mean } \\
\text { GPa }\end{array}$} & \multirow[t]{2}{*}{$\begin{array}{c}\text { St. } \\
\text { Dev. }\end{array}$} & \multicolumn{2}{|c|}{$\begin{array}{c}95 \% \text { confidence } \\
\text { interval on difference } \\
\text { of means }\end{array}$} & \multirow[t]{2}{*}{$\begin{array}{c}\text { Calculated } \\
\text { P value }\end{array}$} & \multirow[t]{2}{*}{$\begin{array}{l}\text { Terminology } \\
\text { (per Table 1) }\end{array}$} & \multirow[t]{2}{*}{$\begin{array}{l}\text { Null } \\
\text { hypothesis } \\
\text { verdict }\end{array}$} \\
\hline & & & & Min & Max & & & \\
\hline $\mathrm{G}_{\mathrm{AG}}(\mathrm{ff})$ & 36 & 4.22 & 0.08 & \multirow[b]{2}{*}{-0.0676} & \multirow[b]{2}{*}{0.0076} & \multirow[b]{2}{*}{0.1161} & \multirow{2}{*}{$\begin{array}{l}\text { Not } \\
\text { statistically } \\
\text { significant }\end{array}$} & \multirow[b]{2}{*}{ Not Rejected } \\
\hline $\mathrm{G}_{\mathrm{AG}}(\mathrm{TOF})$ & 36 & 4.25 & 0.08 & & & & & \\
\hline
\end{tabular}

Acronyms and abbreviations: $\mathrm{TOF}=$ time-of-flight and St. Dev. $=$ standard deviation. 
Table 22. Population statistics and outcome of $t$ testing for with the grain (WG) shear modulus (G) data by sonic velocity (TOF) method and fundamental frequency (ff) method

\begin{tabular}{|c|c|c|c|c|c|c|c|c|}
\hline \multirow[t]{2}{*}{$\begin{array}{l}\text { Population } \\
\text { description }\end{array}$} & \multirow[t]{2}{*}{$\mathbf{n}$} & \multirow[t]{2}{*}{$\begin{array}{c}\text { Mean } \\
\text { GPa }\end{array}$} & \multirow[t]{2}{*}{$\begin{array}{c}\text { St. } \\
\text { Dev. }\end{array}$} & \multicolumn{2}{|c|}{$\begin{array}{c}95 \% \text { confidence } \\
\text { interval on difference } \\
\text { of means }\end{array}$} & \multirow[t]{2}{*}{$\begin{array}{c}\text { Calculated } \\
\text { P value }\end{array}$} & \multirow[t]{2}{*}{$\begin{array}{l}\text { Terminology } \\
\text { (per Table 1) }\end{array}$} & \multirow[t]{2}{*}{$\begin{array}{c}\text { Null } \\
\text { hypothesis } \\
\text { verdict }\end{array}$} \\
\hline & & & & Min & Max & & & \\
\hline $\mathrm{G}_{\mathrm{WG}}(\mathrm{ff})$ & 36 & 4.23 & 0.070 & \multirow{2}{*}{-0.0779} & \multirow{2}{*}{-0.0021} & \multirow{2}{*}{0.0389} & \multirow{2}{*}{$\begin{array}{c}\text { Statistically } \\
\text { significant }\end{array}$} & \multirow{2}{*}{ Rejected } \\
\hline $\mathrm{G}_{\mathrm{WG}}(\mathrm{TOF})$ & 36 & 4.27 & 0.090 & & & & & \\
\hline
\end{tabular}

Acronyms and abbreviations: TOF $=$ time-of-flight and St. Dev. = standard deviation.

\section{Poisson's Ratio}

Table 23. Population statistics and outcome of t testing for against the grain (AG) Poisson's ratio ( $\mu$ ) data by sonic velocity (TOF) method and fundamental frequency (ff) method

\begin{tabular}{|c|c|c|c|c|c|c|c|c|}
\hline \multirow[t]{2}{*}{$\begin{array}{l}\text { Population } \\
\text { description }\end{array}$} & \multirow[t]{2}{*}{ n } & \multirow[t]{2}{*}{ Mean } & \multirow[t]{2}{*}{$\begin{array}{l}\text { St. } \\
\text { Dev. }\end{array}$} & \multicolumn{2}{|c|}{$\begin{array}{c}95 \% \text { confidence } \\
\text { interval on difference } \\
\text { of means }\end{array}$} & \multirow[t]{2}{*}{$\begin{array}{c}\text { Calculated } \\
\text { P value }\end{array}$} & \multirow[t]{2}{*}{$\begin{array}{l}\text { Terminology } \\
\text { (per Table 1) }\end{array}$} & \multirow[t]{2}{*}{$\begin{array}{l}\text { Null } \\
\text { hypothesis } \\
\text { verdict }\end{array}$} \\
\hline & & & & Min & Max & & & \\
\hline$\mu_{\mathrm{AG}}(\mathrm{ff})$ & 36 & 0.17 & 0.02 & \multirow{2}{*}{-0.0274} & \multirow{2}{*}{-0.0126} & \multirow{2}{*}{$>0.0001$} & \multirow{2}{*}{$\begin{array}{l}\text { Extremely } \\
\text { statistically } \\
\text { significant }\end{array}$} & \multirow{2}{*}{ Rejected } \\
\hline$\mu_{\mathrm{AG}}(\mathrm{TOF})$ & 36 & 0.19 & 0.01 & & & & & \\
\hline
\end{tabular}

Acronyms and abbreviations: $\mathrm{TOF}=$ time-of-flight and St. Dev. $=$ standard deviation.

Table 24. Population statistics and outcome of t testing for with the grain (WG) Poisson's ratio ( $\mu$ ) data by sonic velocity (TOF) method and fundamental frequency (ff) method

\begin{tabular}{|c|c|c|c|c|c|c|c|c|}
\hline \multirow[t]{2}{*}{$\begin{array}{l}\text { Population } \\
\text { description }\end{array}$} & \multirow[t]{2}{*}{$\mathbf{N}$} & \multirow[t]{2}{*}{ Mean } & \multirow[t]{2}{*}{$\begin{array}{l}\text { St. } \\
\text { Dev. }\end{array}$} & \multicolumn{2}{|c|}{$\begin{array}{l}95 \% \text { confidence } \\
\text { interval on difference } \\
\text { of means }\end{array}$} & \multirow[t]{2}{*}{$\begin{array}{c}\text { Calculated } \\
\text { P value }\end{array}$} & \multirow[t]{2}{*}{$\begin{array}{l}\text { Terminology } \\
\text { (per Table 1) }\end{array}$} & \multirow[t]{2}{*}{$\begin{array}{l}\text { Null } \\
\text { hypothesis } \\
\text { verdict }\end{array}$} \\
\hline & & & & Min & Max & & & \\
\hline$\mu_{\mathrm{WG}}(\mathrm{ff})$ & 36 & 0.2 & 0.030 & \multirow[b]{2}{*}{-0.0105} & \multirow[b]{2}{*}{0.0105} & \multirow[b]{2}{*}{1.000} & \multirow{2}{*}{$\begin{array}{l}\text { Not } \\
\text { Statistically } \\
\text { significant }\end{array}$} & \multirow[b]{2}{*}{ Not rejected } \\
\hline$\mu_{\mathrm{WG}}(\mathrm{TOF})$ & 36 & 0.2 & 0.010 & & & & & \\
\hline
\end{tabular}

Acronyms and abbreviations: TOF $=$ time-of-flight and St. Dev. = standard deviation.

\section{Corrected Young's Modulus}

Table 25. Population statistics and outcome of t testing for against the grain (AG) Young's modulus (E) data by sonic velocity (TOF) method (Poisson's ratio corrected E) and fundamental frequency (ff) method

\begin{tabular}{|c|c|c|c|c|c|c|c|c|}
\hline \multirow[t]{2}{*}{$\begin{array}{l}\text { Population } \\
\text { description }\end{array}$} & \multirow[t]{2}{*}{$\mathbf{n}$} & \multirow[t]{2}{*}{$\begin{array}{c}\text { Mean } \\
\text { GPa }\end{array}$} & \multirow[t]{2}{*}{$\begin{array}{l}\text { St. } \\
\text { Dev. }\end{array}$} & \multicolumn{2}{|c|}{$\begin{array}{c}95 \% \text { confidence } \\
\text { interval on difference } \\
\text { of means }\end{array}$} & \multirow[t]{2}{*}{$\begin{array}{c}\text { Calculated } \\
\text { P value }\end{array}$} & \multirow[t]{2}{*}{$\begin{array}{l}\text { Terminology } \\
\text { (per Table 1) }\end{array}$} & \multirow{2}{*}{$\begin{array}{l}\text { Null } \\
\text { hypothesis } \\
\text { verdict }\end{array}$} \\
\hline & & & & Min & Max & & & \\
\hline $\mathrm{E}_{\mathrm{AG}}(\mathrm{ff})$ & 36 & 9.92 & 0.31 & \multirow{2}{*}{-0.3383} & \multirow{2}{*}{-0.0817} & \multirow{2}{*}{0.0017} & \multirow{2}{*}{$\begin{array}{l}\text { Very } \\
\text { statistically } \\
\text { significant }\end{array}$} & \multirow{2}{*}{ Rejected } \\
\hline $\mathrm{E}_{\mathrm{AG}}(\mathrm{TOF})$ & 36 & 10.13 & 0.23 & & & & & \\
\hline
\end{tabular}

Acronyms and abbreviations: $\mathrm{TOF}=$ time-of-flight and St. Dev. $=$ standard deviation. 
Table 26. Population statistics and outcome of $t$ testing for with the grain (WG) Young's modulus (E) data by sonic velocity (TOF) method (Poisson's ratio corrected E) and fundamental frequency (ff) method

\begin{tabular}{|c|c|c|c|c|c|c|c|c|}
\hline \multirow[t]{2}{*}{$\begin{array}{l}\text { Population } \\
\text { description }\end{array}$} & \multirow[t]{2}{*}{$\mathbf{n}$} & \multirow[t]{2}{*}{$\begin{array}{c}\text { Mean } \\
\text { GPa }\end{array}$} & \multirow[t]{2}{*}{$\begin{array}{l}\text { St. } \\
\text { Dev. }\end{array}$} & \multicolumn{2}{|c|}{$\begin{array}{c}95 \% \text { confidence } \\
\text { interval on difference } \\
\text { of means }\end{array}$} & \multirow[t]{2}{*}{$\begin{array}{l}\text { Calculated } \\
\text { "P" value }\end{array}$} & \multirow[t]{2}{*}{$\begin{array}{l}\text { Terminology } \\
\text { (per Table 1) }\end{array}$} & \multirow[t]{2}{*}{$\begin{array}{c}\text { Null } \\
\text { hypothesis } \\
\text { verdict }\end{array}$} \\
\hline & & & & Min & Max & & & \\
\hline $\mathrm{E}_{\mathrm{WG}}(\mathrm{ff})$ & 36 & 10.15 & 0.32 & \multirow{2}{*}{-0.247} & \multirow{2}{*}{0.027} & \multirow{2}{*}{0.1139} & \multirow{2}{*}{$\begin{array}{l}\text { Not } \\
\text { Statistically } \\
\text { significant }\end{array}$} & \multirow{2}{*}{ Not Rejected } \\
\hline $\mathrm{E}_{\mathrm{WG}}(\mathrm{TOF})$ & 36 & 10.26 & 0.26 & & & & & \\
\hline
\end{tabular}

Acronyms and abbreviations: $\mathrm{TOF}=$ time-of-flight and St. Dev. $=$ standard deviation.

\section{Billet Data Comparison-E(ff) and $G(f f)$}

On balance the variation (if any) between the test methods was less than $10 \%$, as would be expected for an isotropic graphite (provided the Poisson corrected value of $\mathrm{E}$ is used for the comparison). Data are available for the combined AG and WG E and G modulus values for billet 20570 from testing at INL obtained by the ff method (C747). Data for billet 20570 is compared to the data reported here for billet 116310 (Table A.14 and Table A.18 of Appendix A).

Table 27 reports the mean Young's modulus and shear modulus determined for billets 116310 and 20570 for combined WG and AG specimens. For billet 116310 the Young's modulus was determined using the flat specimen orientation, and the shear modulus was determined using the torsional support. Comparing the means in Table 27 shows that good agreement was attained for the elastic moduli of the two billets.

Table 27. Data for mean Young's modulus and shear modulus for billets 116310 and 20570 (fundamental frequency method only)

\begin{tabular}{|c|c|c|}
\hline \multirow{2}{*}{ Attribute or Property } & \multicolumn{2}{|c|}{ Billet Number } \\
\cline { 2 - 3 } & $\mathbf{1 1 6 3 1 0}$ & $\mathbf{2 0 5 7 0}$ \\
\hline Mean Young's Modulus, E (GPa) & 10 & 9.9 \\
\hline Standard Deviation, Young's Modulus, E (GPa) & 0.33 & 0.37 \\
\hline Number of Specimens & 72 & 190 \\
\hline Mean Shear Modulus, G (GPa) & 4.23 & 4.14 \\
\hline Standard Deviation, Shear Modulus, G (GPa) & 0.5 & 0.07 \\
\hline Number of Specimens & 72 & 190 \\
\hline
\end{tabular}

\subsection{FLEXURE STRENGH}

The flexure strength test data for billet 116310 are in Table A.18 (Appendix A). To determine whether there was any anisotropy in the billet, $t$ testing for the AG and WG orientations was conducted. Locational variations (i.e., between the billet center and end) were extensively investigated with the elastic constants data. Variations noted were $<10 \%$, and so the graphite was considered isotropic, and all flexure strength data were combined. The significance test results for the AG and WG flexure strength are given in Table 28. The $t$ test applies to the null hypothesis $\bar{\chi} \sigma f(A G)=\bar{\chi} \sigma f(W G)$, and there is statistically significant evidence to reject the null hypothesis. However, the differences between the AG and WG means is small $(<10 \%)$, and thus, the graphite is considered isotropic and all the flexural strength data have been combined. 
Table 28. Population statistics and outcome of $t$ testing for with and against the grain (WG and AG) flexure strength $(\sigma)$ of billet 116310

\begin{tabular}{|c|c|c|c|c|c|c|c|c|}
\hline \multirow[t]{2}{*}{$\begin{array}{l}\text { Population } \\
\text { description }\end{array}$} & \multirow[t]{2}{*}{$\mathbf{n}$} & \multirow[t]{2}{*}{$\begin{array}{c}\text { Mean } \\
\text { MPa }\end{array}$} & \multirow[t]{2}{*}{$\begin{array}{l}\text { St. } \\
\text { Dev. }\end{array}$} & \multicolumn{2}{|c|}{$\begin{array}{c}95 \% \text { confidence } \\
\text { interval on difference } \\
\text { of means }\end{array}$} & \multirow[t]{2}{*}{$\begin{array}{l}\text { Calculated } \\
\text { P value }\end{array}$} & \multirow[t]{2}{*}{$\begin{array}{l}\text { Terminology } \\
\text { (per Table 1) }\end{array}$} & \multirow[t]{2}{*}{$\begin{array}{c}\text { Null } \\
\text { hypothesis } \\
\text { verdict }\end{array}$} \\
\hline & & & & Min & Max & & & \\
\hline$\sigma_{\mathrm{f}}(\mathrm{AG})$ & 36 & 41.95 & 3.13 & \multirow{2}{*}{-2.7872} & \multirow{2}{*}{-0.0126} & \multirow{2}{*}{0.048} & \multirow{2}{*}{$\begin{array}{c}\text { Statistically } \\
\text { significant }\end{array}$} & \multirow{2}{*}{ Rejected } \\
\hline$\sigma_{\mathrm{f}}(\mathrm{WG})$ & 36 & 43.35 & 2.76 & & & & & \\
\hline
\end{tabular}

Acronyms and abbreviations: St. Dev. = standard deviation.

The combined population of 72 flexure test bars from billet 116310 are compared to the previously tested billet (20570) in Table 29.

Table 29. Comparison of the mean four-point loading flexural strength of billets 116310 and 20570

(Mersen grade 2114)

\begin{tabular}{|c|c|c|}
\hline \multirow{2}{*}{ Characteristic } & \multicolumn{2}{|c|}{ Billet Number } \\
\cline { 2 - 3 } & $\mathbf{1 1 6 3 1 0}$ & $\mathbf{2 0 5 7 0}$ \\
\hline Mean flexural strength, $\sigma_{\mathrm{f}}(\mathrm{MPa})$ & 42.62 & 40.18 \\
\hline Standard deviation, flexural strength, $\sigma_{\mathrm{f}}(\mathrm{MPa})$ & 3.01 & 2.44 \\
\hline Number of specimens & 72 & 190 \\
\hline
\end{tabular}

The difference between the flexural strength of the two test sets was found to be statistically significant but is attributed to the smaller stressed volume in the case of the ORNL testing, where the loading span was $57 \mathrm{~mm}$ compared to the larger $60 \mathrm{~mm}$ used for billet 20570 . The difference is small $(\sim 6 \%)$, and thus the flexural strength compares well.

\section{SUMMARY AND CONCLUSIONS}

The following conclusions may be drawn from this work.

1. Flexural strength and elastic constants [by ff and ultrasonic velocity (TOF) testing] of 72 grade 2114 graphite specimens with AG or WG orientations from billet 116310 end or center locations have been successfully tested.

2. Data for the flexural strength, bulk density, Poisson's ratio, shear modulus and Young's modulus corrected (for $v$ ) are reported.

3. Statistical significance testing showed the billet to be very slightly anisotropic with respect to strength and elastic properties, the noted variations were less than the $10 \%$ allowed by the ASTM standard specification, ${ }^{13}$ and thus the graphite should be considered an isotropic grade.

4. The small anisotropy noted in the elastic properties was attributed to crystal bond anisotropy and the slight alignment of the filler during forming.

5. For this grade, the two elastic constants test methods, ff (flat beam geometry) and ultrasonic velocity (TOF) - Poisson's corrected Young's modulus, gave comparable data.

6. Agreement between these and prior data for elastic constants and flexural strength was good. 


\section{ACKNOWLEDGMENTS}

This work was supported by the US Department of Energy Office of Nuclear Energy, Advanced Research and Technology-Materials Program. The author wishes to acknowledge the technical assistance of Ashli Clark (ORNL Materials Science and Technology Division, MSTD) and Rick. R. Lowden (MSTD). 


\section{REFERENCES}

1. Burchell, Timothy D., Richard R. Lowden, and Kyle W. Monaghan. 2018. Grade 2114: Preliminary Report of Selected Elastic and Mechanical Properties, ORNL/TM-2018/1038, Oak Ridge, Tennessee: Oak Ridge National Laboratory.

2. Prism, GraphPad Software, QuickCalcs, t test. https://www.graphpad.com/quickcalcs/ttest2/.

3. Chatfield, Christopher. 1983. Statistics for Technology; a Course in Applied Statistics, 3rd ed. Boca Raton, Florida: Chapman and Hall/CRC.

4. Student (William S. Gossett). 1908. "The Probable Error of a Mean.” BIOMETRIKA 6(1): 1-25.

5. Mersen graphite main grades https://www.graphite-eng.com/materials/iso-molded-graphite.

6. Trammell, M. P. 2017. Experimental Plan for the Baseline Characterization of Mersen 2114 Graphite, ORNL/TM-2017/383, Oak Ridge, Tennessee: Oak Ridge National Laboratory.

7. $\quad$ ASTM International. 2016. Standard Test Method for Bulk Density by Physical Measurements of Manufactured Carbon and Graphite Articles, C559-16, West Conshohocken, Pennsylvania: ASTM International.

8. ASTM International. 2015. Sonic Velocity in Manufactured Carbons and Graphite Materials for Use in Obtaining an Approximate Value of Young's Modulus, C769-15, West Conshohocken, Pennsylvania: ASTM International.

9. ASTM International. 2010. Standard Test Method for Moduli of Elasticity and Fundamental Frequencies of Carbon and Graphite Materials by Sonic Resonance, C747-93 (reapproved 2010), West Conshohocken, Pennsylvania: ASTM International.

10. ASTM International. 2015. Standard Test Method for Flexural Strength of Manufactured Carbon and Graphite Articles using Four-Point Loading at Room Temperature, C651-15, West Conshohocken, Pennsylvania: ASTM International.

11. Burchell, Tim, Joel McDuffee, and Ken Thoms. 2014. "Small Specimen Data from a High Temperature HFIR Radiation Experiment," in Graphite Testing for Nuclear Application: The Significance of Test Specimen Volume and Geometry and the Statistical Significance of Test Specimen Population, STP 1578, Athanasia Tzelepi and Mark C. Carroll, Eds., West Conshohocken, Pennsylvania: ASTM International, pp. 172-185.

doi:10.1520/STP157820130121.

12. Katoh, Yuti, Mary A. Snead, Chunghao Shih, Wally D. Porter, Lance L. Snead, and Timothy D. Burchell.2014. "Applicability and Limitations of Miniature Specimens for Properties Determination of Fine-Grained Graphite," in Graphite Testing for Nuclear Application: The Significance of Test Specimen Volume and Geometry and the Statistical Significance of Test Specimen Population, STP 1578, Athanasia Tzelepi and Mark C. Carroll, Eds., West Conshohocken, Pennsylvania: ASTM International, pp. 65-83. doi:10.1520/STP157820130147.

13. ASTM International. 2014. Standard Specification for Isotropic and Near-Isotropic Nuclear Graphites, D7219-08 (reapproved 2014), West Conshohocken, Pennsylvania: ASTM International. 

APPENDIX A. EXPERIMENTAL DATA AND CALCULATED VALUES 



\section{APPENDIX A. EXPERIMENTAL DATA AND CALCULATED VALUES}

Table A.1. Density data measured on the flexure bars

\begin{tabular}{|c|c|c|c|c|c|c|c|c|}
\hline \multirow{2}{*}{$\begin{array}{c}\text { Specimen } \\
\text { number }\end{array}$} & \multirow{2}{*}{ Grain orientation } & \multicolumn{3}{|c|}{ Mean dimensions, $\mathbf{m m}$} & \multirow{2}{*}{$\begin{array}{c}\text { Volume } \\
\mathbf{m}^{3}\end{array}$} & \multirow{2}{*}{$\begin{array}{c}\text { Mass } \\
\mathrm{g}\end{array}$} & \multicolumn{2}{|c|}{ Density } \\
\hline & & Width & Thickness & Length & & & g.cm ${ }^{-3}$ & kg.m-3 \\
\hline 1A1P1P1F & Parallel (AG) & 12.634 & 6.424 & 76.193 & 7.62E-08 & 11.2317 & 1.816 & 1816 \\
\hline 1A1P1P3F & Parallel (AG) & 12.640 & 6.425 & 76.195 & $7.62 \mathrm{E}-08$ & 11.2310 & 1.815 & 1815 \\
\hline 1A1P1P5F & Parallel (AG) & 12.643 & 6.424 & 76.163 & 7.62E-08 & 11.2501 & 1.819 & 1819 \\
\hline 1A1T2L2F & Transverse (WG) & 12.637 & 6.428 & 76.218 & 7.62E-08 & 11.2365 & 1.815 & 1815 \\
\hline 1A1T2L4F & Transverse (WG) & 12.635 & 6.428 & 76.190 & $7.62 \mathrm{E}-08$ & 11.2361 & 1.816 & 1816 \\
\hline 1A1T2L6F & Transverse (WG) & 12.642 & 6.423 & 76.210 & $7.62 \mathrm{E}-08$ & 11.2434 & 1.817 & 1817 \\
\hline 1AIT3L2F & Transverse (WG) & 12.639 & 6.427 & 76.215 & $7.62 \mathrm{E}-08$ & 11.2439 & 1.816 & 1816 \\
\hline 1AIT3L4F & Transverse (WG) & 12.634 & 6.425 & 76.205 & 7.62E-08 & 11.2437 & 1.818 & 1818 \\
\hline 1AIT3L6F & Transverse (WG) & 12.634 & 6.426 & 76.195 & 7.62E-08 & 11.2580 & 1.820 & 1820 \\
\hline 1A1P4P1F & Parallel (AG) & 12.635 & 6.426 & 76.158 & $7.62 \mathrm{E}-08$ & 11.2502 & 1.819 & 1819 \\
\hline 1A1P4P3F & Parallel (AG) & 12.638 & 6.426 & 76.168 & 7.62E-08 & 11.2611 & 1.821 & 1821 \\
\hline 1A1P4P5F & Parallel (AG) & 12.638 & 6.427 & 76.140 & $7.61 \mathrm{E}-08$ & 11.2709 & 1.822 & 1822 \\
\hline 1A4P1P1F & Parallel (AG) & 12.636 & 6.426 & 76.215 & 7.62E-08 & 11.2459 & 1.817 & 1817 \\
\hline 1A4P1P3F & Parallel (AG) & 12.638 & 6.428 & 76.215 & 7.62E-08 & 11.2514 & 1.817 & 1817 \\
\hline 1A4P1P5F & Parallel (AG) & 12.638 & 6.426 & 76.168 & $7.62 \mathrm{E}-08$ & 11.2456 & 1.818 & 1818 \\
\hline 1A4P4P1F & Parallel (AG) & 12.635 & 6.423 & 76.158 & 7.62E-08 & 11.2253 & 1.816 & 1816 \\
\hline 1A4P4P3F & Parallel (AG) & 12.637 & 6.427 & 76.203 & 7.62E-08 & 11.2378 & 1.816 & 1816 \\
\hline 1A4P4P5F & Parallel (AG) & 12.636 & 6.427 & 76.168 & 7.62E-08 & 11.2472 & 1.818 & 1818 \\
\hline 1A4T3L2F & Transverse (WG) & 12.636 & 6.398 & 76.180 & $7.62 \mathrm{E}-08$ & 11.1938 & 1.818 & 1818 \\
\hline 1A4T3L4F & Transverse (WG) & 12.634 & 6.424 & 76.178 & 7.62E-08 & 11.2292 & 1.816 & 1816 \\
\hline 1A4T3L6F & Transverse (WG) & 12.643 & 6.425 & 76.195 & $7.62 \mathrm{E}-08$ & 11.2798 & 1.823 & 1823 \\
\hline 1A4T2L2F & Transverse (WG) & 12.633 & 6.425 & 76.150 & 7.62E-08 & 11.2431 & 1.819 & 1819 \\
\hline 1A4T2L4F & Transverse (WG) & 12.635 & 6.427 & 76.200 & $7.62 \mathrm{E}-08$ & 11.2428 & 1.817 & 1817 \\
\hline 1A4T2L6F & Transverse (WG) & 12.636 & 6.427 & 76.158 & $7.62 \mathrm{E}-08$ & 11.2332 & 1.816 & 1816 \\
\hline 1B2P1PIF & Parallel (AG) & 12.637 & 6.428 & 76.160 & $7.62 \mathrm{E}-08$ & 11.2568 & 1.820 & 1820 \\
\hline 1B2P1P3F & Parallel (AG) & 12.636 & 6.426 & 76.183 & 7.62E-08 & 11.3019 & 1.827 & 1827 \\
\hline 1B2P1P5F & Parallel (AG) & 12.638 & 6.426 & 76.213 & $7.62 \mathrm{E}-08$ & 11.2422 & 1.816 & 1816 \\
\hline
\end{tabular}


Table A.1. Density data measured on the flexure bars (continued)

\begin{tabular}{|c|c|c|c|c|c|c|c|c|}
\hline \multirow{2}{*}{$\begin{array}{l}\text { Specimen } \\
\text { number }\end{array}$} & \multirow{2}{*}{ Grain orientation } & \multicolumn{3}{|c|}{ Mean dimensions, $\mathbf{m m}$} & \multirow{2}{*}{$\begin{array}{c}\text { Volume } \\
\mathbf{m}^{3}\end{array}$} & \multirow{2}{*}{$\begin{array}{c}\text { Mass } \\
\mathbf{g}\end{array}$} & \multicolumn{2}{|c|}{ Density } \\
\hline & & Width & Thickness & Length & & & g.cm ${ }^{-3}$ & kg.m $\mathrm{m}^{-3}$ \\
\hline 1B2P4P1F & Parallel (AG) & 12.637 & 6.427 & 76.198 & 7.62E-08 & 11.2632 & 1.820 & 1820 \\
\hline 1B2P4P3F & Parallel (AG) & 12.632 & 6.425 & 76.200 & $7.62 \mathrm{E}-08$ & 11.2423 & 1.818 & 1818 \\
\hline 1B2P4P5F & Parallel (AG) & 12.635 & 6.428 & 76.145 & 7.61E-08 & 11.2521 & 1.819 & 1819 \\
\hline 1B2T2L2F & Transverse (WG) & 12.632 & 6.423 & 76.198 & $7.62 \mathrm{E}-08$ & 11.2396 & 1.818 & 1818 \\
\hline 1B2T2L4F & Transverse (WG) & 12.639 & 6.425 & 76.180 & $7.62 \mathrm{E}-08$ & 11.2154 & 1.813 & 1813 \\
\hline 1B2T2L6F & Transverse (WG) & 12.641 & 6.425 & 76.183 & 7.62E-08 & 11.2576 & 1.819 & 1819 \\
\hline 1B2T3L2F & Transverse (WG) & 12.640 & 6.425 & 76.175 & $7.62 \mathrm{E}-08$ & 11.2598 & 1.820 & 1820 \\
\hline 1B2T3L4F & Transverse (WG) & 12.636 & 6.428 & 76.170 & $7.62 \mathrm{E}-08$ & 11.2635 & 1.821 & 1821 \\
\hline 1B2T3L6F & Transverse (WG) & 12.648 & 6.425 & 76.155 & 7.62E-08 & 11.2387 & 1.816 & 1816 \\
\hline 1B3P1P1F & Parallel (AG) & 12.639 & 6.422 & 76.173 & 7.62E-08 & 11.3052 & 1.829 & 1829 \\
\hline 1B3P1P3F & Parallel (AG) & 12.637 & 6.423 & 76.175 & 7.62E-08 & 11.3169 & 1.830 & 1830 \\
\hline 1B3P1P5F & Parallel (AG) & 12.637 & 6.426 & 76.170 & 7.62E-08 & 11.3288 & 1.832 & 1832 \\
\hline 1B3P4P1F & Parallel (AG) & 12.633 & 6.425 & 76.173 & 7.62E-08 & 11.2232 & 1.815 & 1815 \\
\hline 1B3P4P3F & Parallel (AG) & 12.637 & 6.426 & 76.170 & 7.62E-08 & 11.2495 & 1.819 & 1819 \\
\hline 1B3P4P5F & Parallel (AG) & 12.634 & 6.425 & 76.185 & 7.62E-08 & 11.2640 & 1.821 & 1821 \\
\hline 1B3T2L2F & Transverse (WG) & 12.640 & 6.428 & 76.158 & $7.62 \mathrm{E}-08$ & 11.3017 & 1.827 & 1827 \\
\hline 1B3T2L4F & Transverse (WG) & 12.636 & 6.427 & 76.208 & 7.62E-08 & 11.2902 & 1.824 & 1824 \\
\hline 1B3T2L6F & Transverse (WG) & 12.636 & 6.422 & 76.193 & 7.62E-08 & 11.2545 & 1.820 & 1820 \\
\hline 1B3T3L2F & Transverse (WG) & 12.634 & 6.425 & 76.178 & $7.62 \mathrm{E}-08$ & 11.2560 & 1.820 & 1820 \\
\hline 1B3T3L4F & Transverse (WG) & 12.639 & 6.427 & 76.213 & 7.62E-08 & 11.2830 & 1.822 & 1822 \\
\hline 1B3T3L6F & Transverse (WG) & 12.640 & 6.427 & 76.190 & 7.62E-08 & 11.2862 & 1.824 & 1824 \\
\hline 5A1P1P1F & Parallel (AG) & 12.647 & 6.431 & 76.185 & $7.62 \mathrm{E}-08$ & 11.2551 & 1.817 & 1817 \\
\hline 5A1P1P3F & Parallel (AG) & 12.648 & 6.426 & 76.195 & 7.62E-08 & 11.2521 & 1.817 & 1817 \\
\hline 5A1P1P5FR & Parallel (AG) & 12.648 & 6.431 & 76.205 & 7.62E-08 & 11.2535 & 1.815 & 1815 \\
\hline 5A1P4P1F & Parallel (AG) & 12.647 & 6.435 & 76.203 & 7.62E-08 & 11.2621 & 1.816 & 1816 \\
\hline 5A1P4P3F & Parallel (AG) & 12.647 & 6.429 & 76.178 & 7.62E-08 & 11.2507 & 1.816 & 1816 \\
\hline 5A1P4P5F & Parallel (AG) & 12.648 & 6.430 & 76.190 & 7.62E-08 & 11.2451 & 1.815 & 1815 \\
\hline 5A1T2L2F & Transverse (WG) & 12.651 & 6.433 & 76.180 & 7.62E-08 & 11.2596 & 1.816 & 1816 \\
\hline 5A1T2L4F & Transverse (WG) & 12.650 & 6.430 & 76.190 & 7.62E-08 & 11.2477 & 1.815 & 1815 \\
\hline 5A1T2L6F & Transverse (WG) & 12.649 & 6.428 & 76.190 & 7.62E-08 & 11.2539 & 1.817 & 1817 \\
\hline
\end{tabular}


Table A.1. Density data measured on the flexure bars (continued)

\begin{tabular}{|c|c|c|c|c|c|c|c|c|}
\hline \multirow{2}{*}{$\begin{array}{c}\text { Specimen } \\
\text { number }\end{array}$} & \multirow{2}{*}{ Grain orientation } & \multicolumn{2}{|c|}{ Mean dimensions, mm } & Volume & Mass & \multicolumn{2}{|c|}{ Density } \\
\cline { 3 - 8 } & & Width & Thickness & Length & $\mathbf{m}^{\mathbf{3}}$ & $\mathbf{g}$ & $\mathbf{g . c m}^{-3}$ & $\mathbf{k g . m}^{-3}$ \\
\hline 5A1T3L2FR & Transverse (WG) & 12.648 & 6.431 & 76.195 & $7.62 \mathrm{E}-08$ & 11.2561 & 1.816 & 1816 \\
\hline 5A1T3L4F & Transverse (WG) & 12.648 & 6.426 & 76.180 & $7.62 \mathrm{E}-08$ & 11.2546 & 1.818 & 1818 \\
\hline 5A1T3L6F & Transverse (WG) & 12.646 & 6.429 & 76.188 & $7.62 \mathrm{E}-08$ & 11.2674 & 1.819 & 1819 \\
\hline & & & & & & & & \\
\hline 5B3P1P1F & Parallel (AG) & 12.647 & 6.426 & 76.188 & $7.62 \mathrm{E}-08$ & 11.2692 & 1.820 & 1820 \\
\hline 5B3P1P3F & Parallel (AG) & 12.651 & 6.431 & 76.210 & $7.62 \mathrm{E}-08$ & 11.2849 & 1.820 & 1820 \\
\hline 5B3P1P5F & Parallel (AG) & 12.647 & 6.429 & 76.175 & $7.62 \mathrm{E}-08$ & 11.2720 & 1.820 & 1820 \\
\hline & & & & & & & & \\
\hline 5B3P4P1F & Parallel (AG) & 12.647 & 6.428 & 76.188 & $7.62 \mathrm{E}-08$ & 11.2906 & 1.823 & 1823 \\
\hline 5B3P4P3F & Parallel (AG) & 12.647 & 6.430 & 76.168 & $7.62 \mathrm{E}-08$ & 11.2933 & 1.823 & 1823 \\
\hline 5B3P4P5FR & Parallel (AG) & 12.646 & 6.426 & 76.178 & $7.62 \mathrm{E}-08$ & 11.2401 & 1.816 & 1816 \\
\hline & & & & & & & & \\
\hline 5B3T2L2FR & Transverse (WG) & 12.648 & 6.423 & 76.183 & $7.62 \mathrm{E}-08$ & 11.2972 & 1.825 & 1825 \\
\hline 5B3T2L4F & Transverse (WG) & 12.641 & 6.427 & 76.200 & $7.62 \mathrm{E}-08$ & 11.2685 & 1.820 & 1820 \\
\hline 5B3T2L6F & Transverse (WG) & 12.646 & 6.431 & 76.180 & $7.62 \mathrm{E}-08$ & 11.2766 & 1.820 & 1820 \\
\hline & & & & & & & & \\
\hline 5B3T3L2F & Transverse (WG) & 12.649 & 6.429 & 76.188 & $7.62 \mathrm{E}-08$ & 11.2707 & 1.819 & 1819 \\
\hline 5B3T3L4F & Transverse (WG) & 12.649 & 6.454 & 76.183 & $7.62 \mathrm{E}-08$ & 11.3228 & 1.821 & 1821 \\
\hline 5B3T3L6F & Transverse (WG) & 12.648 & 6.433 & 76.210 & $7.62 \mathrm{E}-08$ & 11.3159 & 1.825 & 1825 \\
\hline
\end{tabular}


Table A.2. Mersen 2114 graphite bulk density from flexure specimens, sorted by filler orientation

\begin{tabular}{|c|c|c|c|c|c|c|c|}
\hline \multirow{2}{*}{$\begin{array}{l}\text { Specimen } \\
\text { number }\end{array}$} & \multirow{2}{*}{$\begin{array}{c}\text { Grain } \\
\text { orientation }\end{array}$} & \multicolumn{2}{|c|}{ Density } & \multirow{2}{*}{$\begin{array}{l}\text { Specimen } \\
\text { number }\end{array}$} & \multirow{2}{*}{$\begin{array}{c}\text { Grain } \\
\text { orientation }\end{array}$} & \multicolumn{2}{|c|}{ Density } \\
\hline & & g.cm ${ }^{-3}$ & kg.m $\mathrm{m}^{-3}$ & & & g.cm ${ }^{-3}$ & kg.m ${ }^{-3}$ \\
\hline 1A1P1P1F & Parallel (AG) & 1.816 & 1816 & 1A1T2L2F & Transverse (WG) & 1.815 & 1815 \\
\hline 1A1P1P3F & Parallel (AG) & 1.815 & 1815 & 1A1T2L4F & Transverse (WG) & 1.816 & 1816 \\
\hline 1A1P1P5F & Parallel (AG) & 1.819 & 1819 & 1A1T2L6F & Transverse (WG) & 1.817 & 1817 \\
\hline 1A1P4P1F & Parallel (AG) & 1.819 & 1819 & 1AIT3L2F & Transverse (WG) & 1.816 & 1816 \\
\hline 1A1P4P3F & Parallel (AG) & 1.821 & 1821 & 1AIT3L4F & Transverse (WG) & 1.818 & 1818 \\
\hline 1A1P4P5F & Parallel (AG) & 1.822 & 1822 & 1AIT3L6F & Transverse (WG) & 1.820 & 1820 \\
\hline 1A4P1P1F & Parallel (AG) & 1.817 & 1817 & 1A4T3L2F & Transverse (WG) & 1.818 & 1818 \\
\hline 1A4P1P3F & Parallel (AG) & 1.817 & 1817 & 1A4T3L4F & Transverse (WG) & 1.816 & 1816 \\
\hline 1A4P1P5F & Parallel (AG) & 1.818 & 1818 & 1A4T3L6F & Transverse (WG) & 1.823 & 1823 \\
\hline 1A4P4P1F & Parallel (AG) & 1.816 & 1816 & 1A4T2L2F & Transverse (WG) & 1.819 & 1819 \\
\hline 1A4P4P3F & Parallel (AG) & 1.816 & 1816 & 1A4T2L4F & Transverse (WG) & 1.817 & 1817 \\
\hline 1A4P4P5F & Parallel (AG) & 1.818 & 1818 & 1A4T2L6F & Transverse (WG) & 1.816 & 1816 \\
\hline 1B2P1PIF & Parallel (AG) & 1.820 & 1820 & 1B2T2L2F & Transverse (WG) & 1.818 & 1818 \\
\hline 1B2P1P3F & Parallel (AG) & 1.827 & 1827 & 1B2T2L4F & Transverse (WG) & 1.813 & 1813 \\
\hline 1B2P1P5F & Parallel (AG) & 1.816 & 1816 & 1B2T2L6F & Transverse (WG) & 1.819 & 1819 \\
\hline 1B2P4P1F & Parallel (AG) & 1.820 & 1820 & 1B2T3L2F & Transverse (WG) & 1.820 & 1820 \\
\hline 1B2P4P3F & Parallel (AG) & 1.818 & 1818 & 1B2T3L4F & Transverse (WG) & 1.821 & 1821 \\
\hline 1B2P4P5F & Parallel (AG) & 1.819 & 1819 & 1B2T3L6F & Transverse (WG) & 1.816 & 1816 \\
\hline 1B3P1P1F & Parallel (AG) & 1.829 & 1829 & 1B3T2L2F & Transverse (WG) & 1.827 & 1827 \\
\hline 1B3P1P3F & Parallel (AG) & 1.830 & 1830 & 1B3T2L4F & Transverse (WG) & 1.824 & 1824 \\
\hline 1B3P1P5F & Parallel (AG) & 1.832 & 1832 & 1B3T2L6F & Transverse (WG) & 1.820 & 1820 \\
\hline 1B3P4P1F & Parallel (AG) & 1.815 & 1815 & 1B3T3L2F & Transverse (WG) & 1.820 & 1820 \\
\hline 1B3P4P3F & Parallel (AG) & 1.819 & 1819 & 1B3T3L4F & Transverse (WG) & 1.822 & 1822 \\
\hline 1B3P4P5F & Parallel (AG) & 1.821 & 1821 & 1B3T3L6F & Transverse (WG) & 1.824 & 1824 \\
\hline 5A1P1P1F & Parallel (AG) & 1.817 & 1817 & 5A1T2L2F & Transverse (WG) & 1.816 & 1816 \\
\hline 5A1P1P3F & Parallel (AG) & 1.817 & 1817 & 5A1T2L4F & Transverse (WG) & 1.815 & 1815 \\
\hline 5A1P1P5FR & Parallel (AG) & 1.815 & 1815 & 5A1T2L6F & Transverse (WG) & 1.817 & 1817 \\
\hline 5A1P4P1F & Parallel (AG) & 1.816 & 1816 & 5A1T3L2FR & Transverse (WG) & 1.816 & 1816 \\
\hline 5A1P4P3F & Parallel (AG) & 1.816 & 1816 & 5A1T3L4F & Transverse (WG) & 1.818 & 1818 \\
\hline 5A1P4P5F & Parallel (AG) & 1.815 & 1815 & 5A1T3L6F & Transverse (WG) & 1.819 & 1819 \\
\hline
\end{tabular}


Table A.2. Mersen 2114 graphite Bulk Density from flexure specimens, sorted by filler orientation (continued)

\begin{tabular}{|c|c|c|c|c|c|c|c|}
\hline \multirow{2}{*}{$\begin{array}{c}\text { Specimen } \\
\text { number }\end{array}$} & \multirow{2}{*}{$\begin{array}{c}\text { Grain } \\
\text { orientation }\end{array}$} & \multicolumn{2}{|c|}{ Density } & \multirow{2}{*}{$\begin{array}{c}\text { Specimen } \\
\text { number }\end{array}$} & \multirow{2}{*}{$\begin{array}{c}\text { Grain } \\
\text { orientation }\end{array}$} & \multicolumn{2}{|c|}{ Density } \\
\hline & & g.cm ${ }^{-3}$ & kg.m $\mathrm{m}^{-3}$ & & & g.cm ${ }^{-3}$ & kg.m $\mathrm{m}^{-3}$ \\
\hline 5B3P1P1F & Parallel (AG) & 1.820 & 1820 & 5B3T2L2FR & Transverse (WG) & 1.825 & 1825 \\
\hline 5B3P1P3F & Parallel (AG) & 1.820 & 1820 & 5B3T2L4F & Transverse (WG) & 1.820 & 1820 \\
\hline 5B3P1P5F & Parallel (AG) & 1.820 & 1820 & 5B3T2L6F & Transverse (WG) & 1.820 & 1820 \\
\hline 5B3P4P1F & Parallel (AG) & 1.823 & 1823 & 5B3T3L2F & Transverse (WG) & 1.819 & 1819 \\
\hline 5B3P4P3F & Parallel (AG) & 1.823 & 1823 & 5B3T3L4F & Transverse (WG) & 1.821 & 1821 \\
\hline 5B3P4P5FR & Parallel (AG) & 1.816 & 1816 & 5B3T3L6F & Transverse (WG) & 1.825 & 1825 \\
\hline
\end{tabular}


Table A.3. Mersen 2114 graphite bulk density from flexure specimens, sorted by location within the billet (end $=1$, center $=5$ ).

\begin{tabular}{|c|c|c|c|c|c|c|c|}
\hline \multirow{2}{*}{$\begin{array}{l}\text { Specimen } \\
\text { number }\end{array}$} & \multirow{2}{*}{$\begin{array}{c}\text { Grain } \\
\text { orientation }\end{array}$} & \multicolumn{2}{|c|}{ Density } & \multirow{2}{*}{$\begin{array}{l}\text { Specimen } \\
\text { number }\end{array}$} & \multirow{2}{*}{$\begin{array}{c}\text { Grain } \\
\text { orientation }\end{array}$} & \multicolumn{2}{|c|}{ Density } \\
\hline & & g.cm ${ }^{-3}$ & kg. $\mathrm{m}^{-3}$ & & & g.cm ${ }^{-3}$ & kg.m ${ }^{-3}$ \\
\hline 1A1P1P1F & Parallel (AG) & 1.816 & 1816 & 5A1P1P1F & Parallel (AG) & 1.817 & 1817 \\
\hline 1A1P1P3F & Parallel (AG) & 1.815 & 1815 & 5A1P1P3F & Parallel (AG) & 1.817 & 1817 \\
\hline 1A1P1P5F & Parallel (AG) & 1.819 & 1819 & 5A1P1P5FR & Parallel (AG) & 1.815 & 1815 \\
\hline 1A1P4P1F & Parallel (AG) & 1.819 & 1819 & 5A1P4P1F & Parallel (AG) & 1.816 & 1816 \\
\hline 1A1P4P3F & Parallel (AG) & 1.821 & 1821 & 5A1P4P3F & Parallel (AG) & 1.816 & 1816 \\
\hline 1A1P4P5F & Parallel (AG) & 1.822 & 1822 & 5A1P4P5F & Parallel (AG) & 1.815 & 1815 \\
\hline 1A4P1P1F & Parallel (AG) & 1.817 & 1817 & 5B3P1P1F & Parallel (AG) & 1.820 & 1820 \\
\hline 1A4P1P3F & Parallel (AG) & 1.817 & 1817 & 5B3P1P3F & Parallel (AG) & 1.820 & 1820 \\
\hline 1A4P1P5F & Parallel (AG) & 1.818 & 1818 & 5B3P1P5F & Parallel (AG) & 1.820 & 1820 \\
\hline 1A4P4P1F & Parallel (AG) & 1.816 & 1816 & 5B3P4P1F & Parallel (AG) & 1.823 & 1823 \\
\hline 1A4P4P3F & Parallel (AG) & 1.816 & 1816 & 5B3P4P3F & Parallel (AG) & 1.823 & 1823 \\
\hline 1A4P4P5F & Parallel (AG) & 1.818 & 1818 & 5B3P4P5FR & Parallel (AG) & 1.816 & 1816 \\
\hline 1B2P1PIF & Parallel (AG) & 1.820 & 1820 & 5A1T2L2F & Transverse (WG) & 1.816 & 1816 \\
\hline 1B2P1P3F & Parallel (AG) & 1.827 & 1827 & 5A1T2L4F & Transverse (WG) & 1.815 & 1815 \\
\hline 1B2P1P5F & Parallel (AG) & 1.816 & 1816 & 5A1T2L6F & Transverse (WG) & 1.817 & 1817 \\
\hline 1B2P4P1F & Parallel (AG) & 1.820 & 1820 & 5A1T3L2FR & Transverse (WG) & 1.816 & 1816 \\
\hline 1B2P4P3F & Parallel (AG) & 1.818 & 1818 & 5A1T3L4F & Transverse (WG) & 1.818 & 1818 \\
\hline 1B2P4P5F & Parallel (AG) & 1.819 & 1819 & 5A1T3L6F & Transverse (WG) & 1.819 & 1819 \\
\hline 1B3P1P1F & Parallel (AG) & 1.829 & 1829 & 5B3T2L2FR & Transverse (WG) & 1.825 & 1825 \\
\hline 1B3P1P3F & Parallel (AG) & 1.830 & 1830 & 5B3T2L4F & Transverse (WG) & 1.820 & 1820 \\
\hline 1B3P1P5F & Parallel (AG) & 1.832 & 1832 & 5B3T2L6F & Transverse (WG) & 1.820 & 1820 \\
\hline 1B3P4P1F & Parallel (AG) & 1.815 & 1815 & 5B3T3L2F & Transverse (WG) & 1.819 & 1819 \\
\hline 1B3P4P3F & Parallel (AG) & 1.819 & 1819 & 5B3T3L4F & Transverse (WG) & 1.821 & 1821 \\
\hline 1B3P4P5F & Parallel (AG) & 1.821 & 1821 & 5B3T3L6F & Transverse (WG) & 1.825 & 1825 \\
\hline 1A1T2L2F & Transverse (WG) & 1.815 & 1815 & & & & \\
\hline 1A1T2L4F & Transverse (WG) & 1.816 & 1816 & & & & \\
\hline 1A1T2L6F & Transverse (WG) & 1.817 & 1817 & & & & \\
\hline 1AIT3L2F & Transverse (WG) & 1.816 & 1816 & & & & \\
\hline 1AIT3L4F & Transverse (WG) & 1.818 & 1818 & & & & \\
\hline
\end{tabular}


Table A.3. Mersen 2114 graphite bulk density from flexure specimens, sorted by location within the billet (end $=1$, center $=5$ ) (continued)

\begin{tabular}{|c|c|c|c|c|c|c|c|}
\hline \multirow{2}{*}{$\begin{array}{c}\text { Specimen } \\
\text { number }\end{array}$} & \multirow{2}{*}{$\begin{array}{c}\text { Grain } \\
\text { orientation }\end{array}$} & \multicolumn{2}{|c|}{ Density } & \multirow{2}{*}{$\begin{array}{c}\text { Specimen } \\
\text { number }\end{array}$} & \multirow{2}{*}{$\begin{array}{c}\text { Grain } \\
\text { orientation }\end{array}$} & \multicolumn{2}{|c|}{ Density } \\
\hline & & g.cm ${ }^{-3}$ & kg.m ${ }^{-3}$ & & & g.cm ${ }^{-3}$ & kg.m ${ }^{-3}$ \\
\hline 1AIT3L6F & Transverse (WG) & 1.820 & 1820 & & & & \\
\hline 1A4T3L2F & Transverse (WG) & 1.818 & 1818 & & & & \\
\hline 1A4T3L4F & Transverse (WG) & 1.816 & 1816 & & & & \\
\hline 1A4T3L6F & Transverse (WG) & 1.823 & 1823 & & & & \\
\hline $1 \mathrm{~A} 4 \mathrm{~T} 2 \mathrm{~L} 2 \mathrm{~F}$ & Transverse (WG) & 1.819 & 1819 & & & & \\
\hline 1A4T2L4F & Transverse (WG) & 1.817 & 1817 & & & & \\
\hline 1A4T2L6F & Transverse (WG) & 1.816 & 1816 & & & & \\
\hline 1B2T2L2F & Transverse (WG) & 1.818 & 1818 & & & & \\
\hline 1B2T2L4F & Transverse (WG) & 1.813 & 1813 & & & & \\
\hline 1B2T2L6F & Transverse (WG) & 1.819 & 1819 & & & & \\
\hline 1B2T3L2F & Transverse (WG) & 1.820 & 1820 & & & & \\
\hline 1B2T3L4F & Transverse (WG) & 1.821 & 1821 & & & & \\
\hline 1B2T3L6F & Transverse (WG) & 1.816 & 1816 & & & & \\
\hline 1B3T2L2F & Transverse (WG) & 1.827 & 1827 & & & & \\
\hline 1B3T2L4F & Transverse (WG) & 1.824 & 1824 & & & & \\
\hline 1B3T2L6F & Transverse (WG) & 1.820 & 1820 & & & & \\
\hline 1B3T3L2F & Transverse (WG) & 1.820 & 1820 & & & & \\
\hline 1B3T3L4F & Transverse (WG) & 1.822 & 1822 & & & & \\
\hline 1B3T3L6F & Transverse (WG) & 1.824 & 1824 & & & & \\
\hline
\end{tabular}


Table A.4. Young's moduli (by fundamental frequency method) measured on flexural strength specimens in the flat or upright geometries (billet 116310) for with and against grain orientations (WG and AG)

\begin{tabular}{|c|c|c|c|c|c|}
\hline \multirow{2}{*}{$\begin{array}{c}\text { Specimen } \\
\text { number }\end{array}$} & \multirow{2}{*}{ Grain orientation } & \multicolumn{2}{|c|}{ E (upright) } & \multicolumn{2}{|c|}{ E (flat) } \\
\hline & & $\mathbf{P a}$ & GPa & $\mathbf{P a}$ & GPa \\
\hline 1A1P1P1F & Parallel (AG) & $9.63 \mathrm{E}+09$ & 9.63 & $9.48 \mathrm{E}+09$ & 9.48 \\
\hline 1A1P1P3F & Parallel (AG) & $9.75 \mathrm{E}+09$ & 9.75 & $9.58 \mathrm{E}+09$ & 9.58 \\
\hline 1A1P1P5F & Parallel (AG) & $9.85 \mathrm{E}+09$ & 9.85 & $9.74 \mathrm{E}+09$ & 9.74 \\
\hline 1A1T2L2F & Transverse (WG) & $1.04 \mathrm{E}+10$ & 10.35 & $1.01 \mathrm{E}+10$ & 10.14 \\
\hline 1A1T2L4F & Transverse (WG) & $1.02 \mathrm{E}+10$ & 10.16 & $1 \mathrm{E}+10$ & 10.01 \\
\hline 1A1T2L6F & Transverse (WG) & $1.01 \mathrm{E}+10$ & 10.08 & $9.94 \mathrm{E}+09$ & 9.94 \\
\hline 1AIT3L2F & Transverse (WG) & $1.05 \mathrm{E}+10$ & 10.47 & $1.03 \mathrm{E}+10$ & 10.28 \\
\hline 1AIT3L4F & Transverse (WG) & $1.06 \mathrm{E}+10$ & 10.59 & $1.04 \mathrm{E}+10$ & 10.41 \\
\hline 1AIT3L6F & Transverse (WG) & $1.05 \mathrm{E}+10$ & 10.51 & $1.03 \mathrm{E}+10$ & 10.28 \\
\hline 1A1P4P1F & Parallel (AG) & $9.93 \mathrm{E}+09$ & 9.93 & $9.78 \mathrm{E}+09$ & 9.78 \\
\hline 1A1P4P3F & Parallel (AG) & $1.01 \mathrm{E}+10$ & 10.08 & $9.9 \mathrm{E}+09$ & 9.90 \\
\hline 1A1P4P5F & Parallel (AG) & $1.02 \mathrm{E}+10$ & 10.18 & $1 \mathrm{E}+10$ & 10.00 \\
\hline 1A4P1P1F & Parallel (AG) & $1.04 \mathrm{E}+10$ & 10.36 & $1.02 \mathrm{E}+10$ & 10.19 \\
\hline 1A4P1P3F & Parallel (AG) & $1.03 \mathrm{E}+10$ & 10.31 & $1.01 \mathrm{E}+10$ & 10.11 \\
\hline 1A4P1P5F & Parallel (AG) & $1.03 \mathrm{E}+10$ & 10.31 & $1.01 \mathrm{E}+10$ & 10.10 \\
\hline 1A4P4P1F & Parallel (AG) & $1.03 \mathrm{E}+10$ & 10.30 & $1.01 \mathrm{E}+10$ & 10.14 \\
\hline 1A4P4P3F & Parallel (AG) & $1.04 \mathrm{E}+10$ & 10.38 & $1.02 \mathrm{E}+10$ & 10.19 \\
\hline 1A4P4P5F & Parallel (AG) & $1.04 \mathrm{E}+10$ & 10.37 & $1.02 \mathrm{E}+10$ & 10.18 \\
\hline 1A4T3L2F & Transverse (WG) & $9.59 \mathrm{E}+09$ & 9.59 & $9.57 \mathrm{E}+09$ & 9.57 \\
\hline $1 \mathrm{~A} 4 \mathrm{~T} 3 \mathrm{~L} 4 \mathrm{~F}$ & Transverse (WG) & $9.65 \mathrm{E}+09$ & 9.65 & $9.5 \mathrm{E}+09$ & 9.50 \\
\hline 1A4T3L6F & Transverse (WG) & $1 \mathrm{E}+10$ & 10.04 & $9.9 \mathrm{E}+09$ & 9.90 \\
\hline 1A4T2L2F & Transverse $(\mathrm{WG})$ & $9.67 \mathrm{E}+09$ & 9.67 & $9.52 \mathrm{E}+09$ & 9.52 \\
\hline 1A4T2L4F & Transverse (WG) & $9.57 \mathrm{E}+09$ & 9.57 & $9.43 \mathrm{E}+09$ & 9.43 \\
\hline 1A4T2L6F & Transverse (WG) & $9.53 \mathrm{E}+09$ & 9.53 & $9.37 \mathrm{E}+09$ & 9.37 \\
\hline 1B2P1PIF & Parallel (AG) & $9.77 \mathrm{E}+09$ & 9.77 & $9.61 \mathrm{E}+09$ & 9.61 \\
\hline 1B2P1P3F & Parallel (AG) & $1 \mathrm{E}+10$ & 10.04 & $9.85 \mathrm{E}+09$ & 9.85 \\
\hline 1B2P1P5F & Parallel (AG) & $9.48 \mathrm{E}+09$ & 9.48 & $9.36 \mathrm{E}+09$ & 9.36 \\
\hline 1B2P4P1F & Parallel (AG) & $9.68 \mathrm{E}+09$ & 9.68 & $9.52 \mathrm{E}+09$ & 9.52 \\
\hline 1B2P4P3F & Parallel (AG) & $9.61 \mathrm{E}+09$ & 9.61 & $9.45 \mathrm{E}+09$ & 9.45 \\
\hline 1B2P4P5F & Parallel (AG) & $9.72 \mathrm{E}+09$ & 9.72 & $9.55 \mathrm{E}+09$ & 9.55 \\
\hline 1B2T2L2F & Transverse (WG) & $1.04 \mathrm{E}+10$ & 10.37 & $1.02 \mathrm{E}+10$ & 10.17 \\
\hline $1 \mathrm{~B} 2 \mathrm{~T} 2 \mathrm{~L} 4 \mathrm{~F}$ & Transverse (WG) & $1.03 \mathrm{E}+10$ & 10.30 & $1.01 \mathrm{E}+10$ & 10.11 \\
\hline 1B2T2L6F & Transverse (WG) & $1.04 \mathrm{E}+10$ & 10.40 & $1.02 \mathrm{E}+10$ & 10.22 \\
\hline 1B2T3L2F & Transverse (WG) & $1.05 \mathrm{E}+10$ & 10.53 & $1.03 \mathrm{E}+10$ & 10.33 \\
\hline 1B2T3L4F & Transverse (WG) & $1.04 \mathrm{E}+10$ & 10.37 & $1.01 \mathrm{E}+10$ & 10.15 \\
\hline 1B2T3L6F & Transverse (WG) & $1.02 \mathrm{E}+10$ & 10.22 & $1 \mathrm{E}+10$ & 10.04 \\
\hline
\end{tabular}


Table A.4. Young's moduli (by fundamental frequency method) measured on flexural strength specimens in the flat or upright geometries (billet 116310) for with and against grain orientations (WG and AG) (continued)

\begin{tabular}{|c|c|c|c|c|c|}
\hline \multirow{2}{*}{$\begin{array}{c}\text { Specimen } \\
\text { number }\end{array}$} & \multirow{2}{*}{ Grain orientation } & \multicolumn{2}{|c|}{ E (upright) } & \multicolumn{2}{|c|}{ E (flat) } \\
\hline & & $\mathbf{P a}$ & GPa & $\mathbf{P a}$ & GPa \\
\hline 1B3P1P1F & Parallel (AG) & $9.97 \mathrm{E}+09$ & 9.97 & $9.85 \mathrm{E}+09$ & 9.85 \\
\hline 1B3P1P3F & Parallel (AG) & $1.01 \mathrm{E}+10$ & 10.11 & $9.98 \mathrm{E}+09$ & 9.98 \\
\hline 1B3P1P5F & Parallel (AG) & $1.03 \mathrm{E}+10$ & 10.32 & $1.02 \mathrm{E}+10$ & 10.17 \\
\hline 1B3P4P1F & Parallel (AG) & $9.5 \mathrm{E}+09$ & 9.50 & $9.34 \mathrm{E}+09$ & 9.34 \\
\hline 1B3P4P3F & Parallel (AG) & $9.68 \mathrm{E}+09$ & 9.68 & $9.53 \mathrm{E}+09$ & 9.53 \\
\hline 1B3P4P5F & Parallel (AG) & $9.9 \mathrm{E}+09$ & 9.90 & $9.73 \mathrm{E}+09$ & 9.73 \\
\hline 1B3T2L2F & Transverse (WG) & $1.09 \mathrm{E}+10$ & 10.92 & $1.07 \mathrm{E}+10$ & 10.68 \\
\hline 1B3T2L4F & Transverse (WG) & $1.07 \mathrm{E}+10$ & 10.69 & $1.05 \mathrm{E}+10$ & 10.47 \\
\hline 1B3T2L6F & Transverse (WG) & $1.04 \mathrm{E}+10$ & 10.43 & $1.02 \mathrm{E}+10$ & 10.25 \\
\hline 1B3T3L2F & Transverse (WG) & $1.05 \mathrm{E}+10$ & 10.46 & $1.03 \mathrm{E}+10$ & 10.26 \\
\hline 1B3T3L4F & Transverse (WG) & $1.07 \mathrm{E}+10$ & 10.69 & $1.05 \mathrm{E}+10$ & 10.48 \\
\hline 1B3T3L6F & Transverse (WG) & $1.08 \mathrm{E}+10$ & 10.77 & $1.05 \mathrm{E}+10$ & 10.54 \\
\hline 5A1P1P1F & Parallel (AG) & $1.01 \mathrm{E}+10$ & 10.15 & $9.98 \mathrm{E}+09$ & 9.98 \\
\hline 5A1P1P3F & Parallel (AG) & $1.02 \mathrm{E}+10$ & 10.21 & $1 \mathrm{E}+10$ & 10.03 \\
\hline 5A1P1P5FR & Parallel (AG) & $1.03 \mathrm{E}+10$ & 10.27 & $1.01 \mathrm{E}+10$ & 10.09 \\
\hline 5A1P4P1F & Parallel (AG) & $1.01 \mathrm{E}+10$ & 10.09 & $9.88 \mathrm{E}+09$ & 9.88 \\
\hline 5A1P4P3F & Parallel (AG) & $1.01 \mathrm{E}+10$ & 10.09 & $9.92 \mathrm{E}+09$ & 9.92 \\
\hline 5A1P4P5F & Parallel (AG) & $1 \mathrm{E}+10$ & 10.04 & $9.87 \mathrm{E}+09$ & 9.87 \\
\hline 5A1T2L2F & Transverse (WG) & $1.06 \mathrm{E}+10$ & 10.61 & $1.04 \mathrm{E}+10$ & 10.41 \\
\hline $5 \mathrm{~A} 1 \mathrm{~T} 2 \mathrm{~L} 4 \mathrm{~F}$ & Transverse (WG) & $1.06 \mathrm{E}+10$ & 10.60 & $1.04 \mathrm{E}+10$ & 10.44 \\
\hline 5A1T2L6F & Transverse (WG) & $1.05 \mathrm{E}+10$ & 10.51 & $1.03 \mathrm{E}+10$ & 10.34 \\
\hline 5A1T3L2FR & Transverse (WG) & $1.05 \mathrm{E}+10$ & 10.52 & $1.03 \mathrm{E}+10$ & 10.32 \\
\hline 5A1T3L4F & Transverse (WG) & $1.05 \mathrm{E}+10$ & 10.53 & $1.03 \mathrm{E}+10$ & 10.35 \\
\hline 5A1T3L6F & Transverse (WG) & $1.07 \mathrm{E}+10$ & 10.69 & $1.05 \mathrm{E}+10$ & 10.47 \\
\hline 5B3P1P1F & Parallel (AG) & $1.05 \mathrm{E}+10$ & 10.48 & $1.03 \mathrm{E}+10$ & 10.29 \\
\hline 5B3P1P3F & Parallel (AG) & $1.05 \mathrm{E}+10$ & 10.49 & $1.03 \mathrm{E}+10$ & 10.32 \\
\hline 5B3P1P5F & Parallel (AG) & $1.05 \mathrm{E}+10$ & 10.47 & $1.03 \mathrm{E}+10$ & 10.29 \\
\hline 5B3P4P1F & Parallel (AG) & $1.06 \mathrm{E}+10$ & 10.62 & $1.04 \mathrm{E}+10$ & 10.40 \\
\hline 5B3P4P3F & Parallel (AG) & $1.06 \mathrm{E}+10$ & 10.61 & $1.04 \mathrm{E}+10$ & 10.41 \\
\hline 5B3P4P5FR & Parallel (AG) & $1.05 \mathrm{E}+10$ & 10.46 & $1.03 \mathrm{E}+10$ & 10.31 \\
\hline 5B3T2L2FR & Transverse (WG) & $1.04 \mathrm{E}+10$ & 10.37 & $1.02 \mathrm{E}+10$ & 10.18 \\
\hline $5 \mathrm{~B} 3 \mathrm{~T} 2 \mathrm{~L} 4 \mathrm{~F}$ & Transverse (WG) & $1.03 \mathrm{E}+10$ & 10.27 & $1.01 \mathrm{E}+10$ & 10.08 \\
\hline 5B3T2L6F & Transverse (WG) & $1.03 \mathrm{E}+10$ & 10.32 & $1.01 \mathrm{E}+10$ & 10.14 \\
\hline 5B3T3L2F & Transverse (WG) & $1.02 \mathrm{E}+10$ & 10.23 & $1.01 \mathrm{E}+10$ & 10.06 \\
\hline 5B3T3L4F & Transverse (WG) & $1.04 \mathrm{E}+10$ & 10.37 & $1.01 \mathrm{E}+10$ & 10.10 \\
\hline 5B3T3L6F & Transverse (WG) & $1.03 \mathrm{E}+10$ & 10.25 & $1.01 \mathrm{E}+10$ & 10.06 \\
\hline
\end{tabular}


Table A.5. Young's moduli (by fundamental frequency method) measured on flexural strength specimens in the flat orientation (billet ' 116310 ) sorted by grain orientation

\begin{tabular}{|c|c|c|c|c|c|c|c|}
\hline \multirow{2}{*}{$\begin{array}{l}\text { Specimen } \\
\text { number }\end{array}$} & \multirow{2}{*}{$\begin{array}{c}\text { Grain } \\
\text { orientation }\end{array}$} & \multicolumn{2}{|c|}{ E (flat) } & \multirow{2}{*}{$\begin{array}{l}\text { Specimen } \\
\text { number }\end{array}$} & \multirow{2}{*}{$\begin{array}{c}\text { Grain } \\
\text { orientation }\end{array}$} & \multicolumn{2}{|c|}{ E (flat) } \\
\hline & & $\mathbf{P a}$ & GPa & & & $\mathbf{P a}$ & GPa \\
\hline 1A1P1P1F & Parallel (AG) & $9.48 \mathrm{E}+09$ & 9.48 & 1A1T2L2F & Transverse (WG) & $1.01 \mathrm{E}+10$ & 10.14 \\
\hline 1A1P1P3F & Parallel (AG) & $9.58 \mathrm{E}+09$ & 9.58 & 1A1T2L4F & Transverse (WG) & $1 \mathrm{E}+10$ & 10.01 \\
\hline 1A1P1P5F & Parallel (AG) & $9.74 \mathrm{E}+09$ & 9.74 & 1A1T2L6F & Transverse (WG) & $9.94 \mathrm{E}+09$ & 9.94 \\
\hline 1A1P4P1F & Parallel (AG) & $9.78 \mathrm{E}+09$ & 9.78 & 1AIT3L2F & Transverse (WG) & $1.03 \mathrm{E}+10$ & 10.28 \\
\hline 1A1P4P3F & Parallel (AG) & $9.9 \mathrm{E}+09$ & 9.90 & 1AIT3L4F & Transverse (WG) & $1.04 \mathrm{E}+10$ & 10.41 \\
\hline 1A1P4P5F & Parallel (AG) & $1 \mathrm{E}+10$ & 10.00 & 1AIT3L6F & Transverse (WG) & $1.03 \mathrm{E}+10$ & 10.28 \\
\hline 1A4P1P1F & Parallel (AG) & $1.02 \mathrm{E}+10$ & 10.19 & 1A4T3L2F & Transverse (WG) & $9.57 \mathrm{E}+09$ & 9.57 \\
\hline 1A4P1P3F & Parallel (AG) & $1.01 \mathrm{E}+10$ & 10.11 & 1A4T3L4F & Transverse (WG) & $9.5 \mathrm{E}+09$ & 9.50 \\
\hline 1A4P1P5F & Parallel (AG) & $1.01 \mathrm{E}+10$ & 10.10 & 1A4T3L6F & Transverse (WG) & $9.9 \mathrm{E}+09$ & 9.90 \\
\hline 1A4P4P1F & Parallel (AG) & $1.01 \mathrm{E}+10$ & 10.14 & 1A4T2L2F & Transverse (WG) & $9.52 \mathrm{E}+09$ & 9.52 \\
\hline 1A4P4P3F & Parallel (AG) & $1.02 \mathrm{E}+10$ & 10.19 & 1A4T2L4F & Transverse (WG) & $9.43 \mathrm{E}+09$ & 9.43 \\
\hline 1A4P4P5F & Parallel (AG) & $1.02 \mathrm{E}+10$ & 10.18 & 1A4T2L6F & Transverse (WG) & $9.37 \mathrm{E}+09$ & 9.37 \\
\hline 1B2P1PIF & Parallel (AG) & $9.61 \mathrm{E}+09$ & 9.61 & 1B2T2L2F & Transverse (WG) & $1.02 \mathrm{E}+10$ & 10.17 \\
\hline 1B2P1P3F & Parallel (AG) & $9.85 \mathrm{E}+09$ & 9.85 & 1B2T2L4F & Transverse (WG) & $1.01 \mathrm{E}+10$ & 10.11 \\
\hline 1B2P1P5F & Parallel (AG) & $9.36 \mathrm{E}+09$ & 9.36 & 1B2T2L6F & Transverse (WG) & $1.02 \mathrm{E}+10$ & 10.22 \\
\hline 1B2P4P1F & Parallel (AG) & $9.52 \mathrm{E}+09$ & 9.52 & 1B2T3L2F & Transverse (WG) & $1.03 \mathrm{E}+10$ & 10.33 \\
\hline 1B2P4P3F & Parallel (AG) & $9.45 \mathrm{E}+09$ & 9.45 & 1B2T3L4F & Transverse (WG) & $1.01 \mathrm{E}+10$ & 10.15 \\
\hline 1B2P4P5F & Parallel (AG) & $9.55 \mathrm{E}+09$ & 9.55 & 1B2T3L6F & Transverse (WG) & $1 \mathrm{E}+10$ & 10.04 \\
\hline 1B3P1P1F & Parallel (AG) & $9.85 \mathrm{E}+09$ & 9.85 & 1B3T2L2F & Transverse (WG) & $1.07 \mathrm{E}+10$ & 10.68 \\
\hline 1B3P1P3F & Parallel (AG) & $9.98 \mathrm{E}+09$ & 9.98 & 1B3T2L4F & Transverse (WG) & $1.05 \mathrm{E}+10$ & 10.47 \\
\hline 1B3P1P5F & Parallel (AG) & $1.02 \mathrm{E}+10$ & 10.17 & 1B3T2L6F & Transverse (WG) & $1.02 \mathrm{E}+10$ & 10.25 \\
\hline 1B3P4P1F & Parallel (AG) & $9.34 \mathrm{E}+09$ & 9.34 & 1B3T3L2F & Transverse (WG) & $1.03 \mathrm{E}+10$ & 10.26 \\
\hline 1B3P4P3F & Parallel (AG) & $9.53 \mathrm{E}+09$ & 9.53 & 1B3T3L4F & Transverse (WG) & $1.05 \mathrm{E}+10$ & 10.48 \\
\hline 1B3P4P5F & Parallel (AG) & $9.73 \mathrm{E}+09$ & 9.73 & 1B3T3L6F & Transverse (WG) & $1.05 \mathrm{E}+10$ & 10.54 \\
\hline 5A1P1P1F & Parallel (AG) & $9.98 \mathrm{E}+09$ & 9.98 & 5A1T2L2F & Transverse (WG) & $1.04 \mathrm{E}+10$ & 10.41 \\
\hline 5A1P1P3F & Parallel (AG) & $1 \mathrm{E}+10$ & 10.03 & 5A1T2L4F & Transverse (WG) & $1.04 \mathrm{E}+10$ & 10.44 \\
\hline 5A1P1P5FR & Parallel (AG) & $1.01 \mathrm{E}+10$ & 10.09 & 5A1T2L6F & Transverse (WG) & $1.03 \mathrm{E}+10$ & 10.34 \\
\hline 5A1P4P1F & Parallel (AG) & $9.88 \mathrm{E}+09$ & 9.88 & 5A1T3L2FR & Transverse (WG) & $1.03 \mathrm{E}+10$ & 10.32 \\
\hline 5A1P4P3F & Parallel (AG) & $9.92 \mathrm{E}+09$ & 9.92 & 5A1T3L4F & Transverse (WG) & $1.03 \mathrm{E}+10$ & 10.35 \\
\hline 5A1P4P5F & Parallel (AG) & $9.87 \mathrm{E}+09$ & 9.87 & 5A1T3L6F & Transverse (WG) & $1.05 \mathrm{E}+10$ & 10.47 \\
\hline
\end{tabular}


Table A.5. Young's moduli (by fundamental frequency method) measured on flexural strength specimens in the flat orientation (billet 116310) sorted by grain orientation (continued)

\begin{tabular}{|c|c|c|c|c|c|c|c|}
\hline \multirow{2}{*}{$\begin{array}{l}\text { Specimen } \\
\text { number }\end{array}$} & \multirow{2}{*}{$\begin{array}{c}\text { Grain } \\
\text { orientation }\end{array}$} & \multicolumn{2}{|c|}{ E (flat) } & \multirow{2}{*}{$\begin{array}{l}\text { Specimen } \\
\text { number }\end{array}$} & \multirow{2}{*}{$\begin{array}{c}\text { Grain } \\
\text { orientation }\end{array}$} & \multicolumn{2}{|c|}{ E (flat) } \\
\hline & & $\mathbf{P a}$ & GPa & & & $\mathbf{P a}$ & GPa \\
\hline 5B3P1P1F & Parallel (AG) & $1.03 \mathrm{E}+10$ & 10.29 & 5B3T2L2FR & Transverse (WG) & $1.02 \mathrm{E}+10$ & 10.18 \\
\hline 5B3P1P3F & Parallel (AG) & $1.03 \mathrm{E}+10$ & 10.32 & 5B3T2L4F & Transverse (WG) & $1.01 \mathrm{E}+10$ & 10.08 \\
\hline 5B3P1P5F & Parallel (AG) & $1.03 \mathrm{E}+10$ & 10.29 & 5B3T2L6F & Transverse (WG) & $1.01 \mathrm{E}+10$ & 10.14 \\
\hline 5B3P4P1F & Parallel (AG) & $1.04 \mathrm{E}+10$ & 10.40 & 5B3T3L2F & Transverse $(\mathrm{WG})$ & $1.01 \mathrm{E}+10$ & 10.06 \\
\hline 5B3P4P3F & Parallel (AG) & $1.04 \mathrm{E}+10$ & 10.41 & 5B3T3L4F & Transverse (WG) & $1.01 \mathrm{E}+10$ & 10.10 \\
\hline 5B3P4P5FR & Parallel (AG) & $1.03 \mathrm{E}+10$ & 10.31 & 5B3T3L6F & Transverse (WG) & $1.01 \mathrm{E}+10$ & 10.06 \\
\hline
\end{tabular}


Table A.6. Young's moduli (by fundamental frequency method) measured on WG flexural strength specimens in the flat orientation (billet 116310) sorted by in-billet position (end vs. center)

\begin{tabular}{|c|c|c|c|c|c|c|c|}
\hline \multirow{2}{*}{$\begin{array}{c}\text { Specimen } \\
\text { number }\end{array}$} & \multirow{2}{*}{$\begin{array}{c}\text { Grain } \\
\text { orientation }\end{array}$} & \multicolumn{2}{|c|}{ E (flat) } & \multirow{2}{*}{$\begin{array}{l}\text { Specimen } \\
\text { number }\end{array}$} & \multirow{2}{*}{$\begin{array}{c}\text { Grain } \\
\text { orientation }\end{array}$} & \multicolumn{2}{|c|}{ E (flat) } \\
\hline & & $\mathbf{P a}$ & GPa & & & $\mathbf{P a}$ & GPa \\
\hline 1A1T2L2F & Transverse (WG) & $1.01 \mathrm{E}+10$ & 10.14 & $5 \mathrm{~A} 1 \mathrm{~T} 2 \mathrm{~L} 2 \mathrm{~F}$ & Transverse (WG) & $1.04 \mathrm{E}+10$ & 10.41 \\
\hline 1A1T2L4F & Transverse (WG) & $1 \mathrm{E}+10$ & 10.01 & 5A1T2L4F & Transverse (WG) & $1.04 \mathrm{E}+10$ & 10.44 \\
\hline 1A1T2L6F & Transverse (WG) & $9.94 \mathrm{E}+09$ & 9.94 & $5 \mathrm{~A} 1 \mathrm{~T} 2 \mathrm{~L} 6 \mathrm{~F}$ & Transverse (WG) & $1.03 \mathrm{E}+10$ & 10.34 \\
\hline 1AIT3L2F & Transverse (WG) & $1.03 \mathrm{E}+10$ & 10.28 & 5A1T3L2FR & Transverse (WG) & $1.03 \mathrm{E}+10$ & 10.32 \\
\hline 1AIT3L4F & Transverse (WG) & $1.04 \mathrm{E}+10$ & 10.41 & 5A1T3L4F & Transverse (WG) & $1.03 \mathrm{E}+10$ & 10.35 \\
\hline 1AIT3L6F & Transverse (WG) & $1.03 \mathrm{E}+10$ & 10.28 & 5A1T3L6F & Transverse (WG) & $1.05 \mathrm{E}+10$ & 10.47 \\
\hline 1A4T3L2F & Transverse (WG) & $9.57 \mathrm{E}+09$ & 9.57 & 5B3T2L2FR & Transverse (WG) & $1.02 \mathrm{E}+10$ & 10.18 \\
\hline 1A4T3L4F & Transverse (WG) & $9.5 \mathrm{E}+09$ & 9.50 & 5B3T2L4F & Transverse (WG) & $1.01 \mathrm{E}+10$ & 10.08 \\
\hline 1A4T3L6F & Transverse (WG) & $9.9 \mathrm{E}+09$ & 9.90 & 5B3T2L6F & Transverse (WG) & $1.01 \mathrm{E}+10$ & 10.14 \\
\hline 1A4T2L2F & Transverse (WG) & $9.52 \mathrm{E}+09$ & 9.52 & 5B3T3L2F & Transverse (WG) & $1.01 \mathrm{E}+10$ & 10.06 \\
\hline 1A4T2L4F & Transverse (WG) & $9.43 \mathrm{E}+09$ & 9.43 & 5B3T3L4F & Transverse (WG) & $1.01 \mathrm{E}+10$ & 10.10 \\
\hline 1A4T2L6F & Transverse (WG) & $9.37 \mathrm{E}+09$ & 9.37 & 5B3T3L6F & Transverse (WG) & $1.01 \mathrm{E}+10$ & 10.06 \\
\hline 1B2T2L2F & Transverse (WG) & $1.02 \mathrm{E}+10$ & 10.17 & & & & \\
\hline 1B2T2L4F & Transverse (WG) & $1.01 \mathrm{E}+10$ & 10.11 & & & & \\
\hline 1B2T2L6F & Transverse (WG) & $1.02 \mathrm{E}+10$ & 10.22 & & & & \\
\hline 1B2T3L2F & Transverse (WG) & $1.03 \mathrm{E}+10$ & 10.33 & & & & \\
\hline 1B2T3L4F & Transverse (WG) & $1.01 \mathrm{E}+10$ & 10.15 & & & & \\
\hline 1B2T3L6F & Transverse (WG) & $1 \mathrm{E}+10$ & 10.04 & & & & \\
\hline 1B3T2L2F & Transverse (WG) & $1.07 \mathrm{E}+10$ & 10.68 & & & & \\
\hline 1B3T2L4F & Transverse (WG) & $1.05 \mathrm{E}+10$ & 10.47 & & & & \\
\hline 1B3T2L6F & Transverse (WG) & $1.02 \mathrm{E}+10$ & 10.25 & & & & \\
\hline 1B3T3L2F & Transverse (WG) & $1.03 \mathrm{E}+10$ & 10.26 & & & & \\
\hline 1B3T3L4F & Transverse (WG) & $1.05 \mathrm{E}+10$ & 10.48 & & & & \\
\hline 1B3T3L6F & Transverse (WG) & $1.05 \mathrm{E}+10$ & 10.54 & & & & \\
\hline
\end{tabular}


Table A.7. Young's moduli (by fundamental frequency method) measured on AG flexural strength specimens in the flat orientation (billet 116310) sorted by in-billet position (end vs. center)

\begin{tabular}{|c|c|c|c|c|c|c|c|}
\hline \multirow{2}{*}{$\begin{array}{l}\text { Specimen } \\
\text { number }\end{array}$} & \multirow{2}{*}{$\begin{array}{c}\text { Grain } \\
\text { orientation }\end{array}$} & \multicolumn{2}{|c|}{ E (flat) } & \multirow{2}{*}{$\begin{array}{c}\text { Specimen } \\
\text { number }\end{array}$} & \multirow{2}{*}{$\begin{array}{c}\text { Grain } \\
\text { orientation }\end{array}$} & \multicolumn{2}{|c|}{ E (flat) } \\
\hline & & $\mathbf{P a}$ & GPa & & & $\mathbf{P a}$ & GPa \\
\hline 1A1P1P1F & Parallel (AG) & $9.48 \mathrm{E}+09$ & 9.48 & 5A1P1P1F & Parallel (AG) & $9.98 \mathrm{E}+09$ & 9.98 \\
\hline 1A1P1P3F & Parallel (AG) & $9.58 \mathrm{E}+09$ & 9.58 & 5A1P1P3F & Parallel (AG) & $1 \mathrm{E}+10$ & 10.03 \\
\hline 1A1P1P5F & Parallel (AG) & $9.74 \mathrm{E}+09$ & 9.74 & 5A1P1P5FR & Parallel (AG) & $1.01 \mathrm{E}+10$ & 10.09 \\
\hline 1A1P4P1F & Parallel (AG) & $9.78 \mathrm{E}+09$ & 9.78 & 5A1P4P1F & Parallel (AG) & $9.88 \mathrm{E}+09$ & 9.88 \\
\hline 1A1P4P3F & Parallel (AG) & $9.9 \mathrm{E}+09$ & 9.90 & 5A1P4P3F & Parallel (AG) & $9.92 \mathrm{E}+09$ & 9.92 \\
\hline 1A1P4P5F & Parallel (AG) & $1 \mathrm{E}+10$ & 10.00 & 5A1P4P5F & Parallel (AG) & $9.87 \mathrm{E}+09$ & 9.87 \\
\hline 1A4P1P1F & Parallel (AG) & $1.02 \mathrm{E}+10$ & 10.19 & 5B3P1P1F & Parallel (AG) & $1.03 \mathrm{E}+10$ & 10.29 \\
\hline 1A4P1P3F & Parallel (AG) & $1.01 \mathrm{E}+10$ & 10.11 & 5B3P1P3F & Parallel (AG) & $1.03 \mathrm{E}+10$ & 10.32 \\
\hline 1A4P1P5F & Parallel (AG) & $1.01 \mathrm{E}+10$ & 10.10 & 5B3P1P5F & Parallel (AG) & $1.03 \mathrm{E}+10$ & 10.29 \\
\hline 1A4P4P1F & Parallel (AG) & $1.01 \mathrm{E}+10$ & 10.14 & 5B3P4P1F & Parallel (AG) & $1.04 \mathrm{E}+10$ & 10.40 \\
\hline 1A4P4P3F & Parallel (AG) & $1.02 \mathrm{E}+10$ & 10.19 & 5B3P4P3F & Parallel (AG) & $1.04 \mathrm{E}+10$ & 10.41 \\
\hline 1A4P4P5F & Parallel (AG) & $1.02 \mathrm{E}+10$ & 10.18 & 5B3P4P5FR & Parallel (AG) & $1.03 \mathrm{E}+10$ & 10.31 \\
\hline 1B2P1PIF & Parallel (AG) & $9.61 \mathrm{E}+09$ & 9.61 & & & & \\
\hline 1B2P1P3F & Parallel (AG) & $9.85 \mathrm{E}+09$ & 9.85 & & & & \\
\hline 1B2P1P5F & Parallel (AG) & $9.36 \mathrm{E}+09$ & 9.36 & & & & \\
\hline 1B2P4P1F & Parallel (AG) & $9.52 \mathrm{E}+09$ & 9.52 & & & & \\
\hline 1B2P4P3F & Parallel (AG) & $9.45 \mathrm{E}+09$ & 9.45 & & & & \\
\hline 1B2P4P5F & Parallel (AG) & $9.55 \mathrm{E}+09$ & 9.55 & & & & \\
\hline 1B3P1P1F & Parallel (AG) & $9.85 \mathrm{E}+09$ & 9.85 & & & & \\
\hline 1B3P1P3F & Parallel (AG) & $9.98 \mathrm{E}+09$ & 9.98 & & & & \\
\hline 1B3P1P5F & Parallel (AG) & $1.02 \mathrm{E}+10$ & 10.17 & & & & \\
\hline 1B3P4P1F & Parallel (AG) & $9.34 \mathrm{E}+09$ & 9.34 & & & & \\
\hline 1B3P4P3F & Parallel (AG) & $9.53 \mathrm{E}+09$ & 9.53 & & & & \\
\hline 1B3P4P5F & Parallel (AG) & $9.73 E+09$ & 9.73 & & & & \\
\hline
\end{tabular}


Table A.8. Shear moduli (by fundamental frequency method) measured on flexural strength specimens in the torsional vibration mode (billet 116310 ) sorted by grain orientation

\begin{tabular}{|c|c|c|c|c|c|c|c|}
\hline \multirow{2}{*}{$\begin{array}{l}\text { Specimen } \\
\text { number }\end{array}$} & \multirow{2}{*}{$\begin{array}{c}\text { Grain } \\
\text { orientation }\end{array}$} & \multicolumn{2}{|c|}{ Shear modulus, G } & \multirow{2}{*}{$\begin{array}{l}\text { Specimen } \\
\text { number }\end{array}$} & \multirow{2}{*}{$\begin{array}{c}\text { Grain } \\
\text { orientation }\end{array}$} & \multicolumn{2}{|c|}{ Shear modulus, $G$} \\
\hline & & $\mathbf{P a}$ & GPa & & & $\mathbf{P a}$ & GPa \\
\hline 1A1P1P1F & Parallel (AG) & $4.12 \mathrm{E}+09$ & 4.12 & 1A1T2L2F & Transverse (WG) & $4.17 \mathrm{E}+09$ & 4.17 \\
\hline 1A1P1P3F & Parallel (AG) & $4.1 \mathrm{E}+09$ & 4.10 & 1A1T2L4F & Transverse (WG) & $4.19 \mathrm{E}+09$ & 4.19 \\
\hline 1A1P1P5F & Parallel (AG) & $4.19 \mathrm{E}+09$ & 4.19 & 1A1T2L6F & Transverse (WG) & $4.22 \mathrm{E}+09$ & 4.22 \\
\hline 1A1P4P1F & Parallel (AG) & $4.28 \mathrm{E}+09$ & 4.28 & 1AIT3L2F & Transverse (WG) & $4.25 \mathrm{E}+09$ & 4.25 \\
\hline 1A1P4P3F & Parallel (AG) & $4.3 \mathrm{E}+09$ & 4.30 & 1AIT3L4F & Transverse (WG) & $4.31 \mathrm{E}+09$ & 4.31 \\
\hline 1A1P4P5F & Parallel (AG) & $4.27 \mathrm{E}+09$ & 4.27 & 1AIT3L6F & Transverse (WG) & $4.28 \mathrm{E}+09$ & 4.28 \\
\hline 1A4P1P1F & Parallel (AG) & $4.26 \mathrm{E}+09$ & 4.26 & 1A4T3L2F & Transverse (WG) & $4.15 \mathrm{E}+09$ & 4.15 \\
\hline 1A4P1P3F & Parallel (AG) & $4.21 \mathrm{E}+09$ & 4.21 & 1A4T3L4F & Transverse (WG) & $4.11 \mathrm{E}+09$ & 4.11 \\
\hline 1A4P1P5F & Parallel (AG) & $4.13 \mathrm{E}+09$ & 4.13 & 1A4T3L6F & Transverse (WG) & $4.28 \mathrm{E}+09$ & 4.28 \\
\hline 1A4P4P1F & Parallel (AG) & $4.29 \mathrm{E}+09$ & 4.29 & 1A4T2L2F & Transverse (WG) & $4.14 \mathrm{E}+09$ & 4.14 \\
\hline 1A4P4P3F & Parallel (AG) & $4.23 \mathrm{E}+09$ & 4.23 & 1A4T2L4F & Transverse (WG) & $4.15 \mathrm{E}+09$ & 4.15 \\
\hline 1A4P4P5F & Parallel (AG) & $4.28 \mathrm{E}+09$ & 4.28 & 1A4T2L6F & Transverse (WG) & $4.15 \mathrm{E}+09$ & 4.15 \\
\hline 1B2P1PIF & Parallel (AG) & $4.16 \mathrm{E}+09$ & 4.16 & 1B2T2L2F & Transverse (WG) & $4.17 \mathrm{E}+09$ & 4.17 \\
\hline 1B2P1P3F & Parallel (AG) & $4.27 \mathrm{E}+09$ & 4.27 & 1B2T2L4F & Transverse (WG) & $4.11 \mathrm{E}+09$ & 4.11 \\
\hline 1B2P1P5F & Parallel (AG) & $4.09 \mathrm{E}+09$ & 4.09 & 1B2T2L6F & Transverse (WG) & $4.3 \mathrm{E}+09$ & 4.30 \\
\hline 1B2P4P1F & Parallel (AG) & $4.11 \mathrm{E}+09$ & 4.11 & 1B2T3L2F & Transverse (WG) & $4.29 \mathrm{E}+09$ & 4.29 \\
\hline 1B2P4P3F & Parallel (AG) & $4.12 \mathrm{E}+09$ & & T3L4F & Transverse (WG) & $4.21 \mathrm{E}+09$ & 4.21 \\
\hline 1B2P4P5F & Parallel (AG) & $4.12 \mathrm{E}+09$ & 4.12 & 1B2T3L6F & Transverse (WG) & $4.11 \mathrm{E}+09$ & 4.11 \\
\hline 1B3P1P1F & Parallel (AG) & $4.3 \mathrm{E}+09$ & 4.30 & 1B3T2L2F & Transverse (WG) & $4.34 \mathrm{E}+09$ & 4.34 \\
\hline 1B3P1P3F & Parallel (AG) & $4.37 \mathrm{E}+09$ & 4.37 & 1B3T2L4F & Transverse (WG) & $4.15 \mathrm{E}+09$ & 4.15 \\
\hline 1B3P1P5F & Parallel (AG) & $4.36 \mathrm{E}+09$ & 4.36 & 1B3T2L6F & Transverse (WG) & $4.28 \mathrm{E}+09$ & 4.28 \\
\hline 1B3P4P1F & Parallel (AG) & $4.07 \mathrm{E}+09$ & 4.07 & 1B3T3L2F & Transverse (WG) & $4.22 \mathrm{E}+09$ & 4.22 \\
\hline 1B3P4P3F & Parallel (AG) & $4.15 \mathrm{E}+09$ & 4.15 & 1B3T3L4F & Transverse (WG) & $4.27 \mathrm{E}+09$ & 4.27 \\
\hline 1B3P4P5F & Parallel (AG) & $4.2 \mathrm{E}+09$ & 4.20 & 1B3T3L6F & Transverse (WG) & $4.28 \mathrm{E}+09$ & 4.28 \\
\hline 5A1P1P1F & Parallel (AG) & $4.21 \mathrm{E}+09$ & 4.21 & $5 \mathrm{~A} 1 \mathrm{~T} 2 \mathrm{~L} 2 \mathrm{~F}$ & Transverse (WG) & $4.3 \mathrm{E}+09$ & 4.30 \\
\hline 5A1P1P3F & Parallel (AG) & $4.23 \mathrm{E}+09$ & 4.23 & 5A1T2L4F & Transverse (WG) & $4.29 \mathrm{E}+09$ & 4.29 \\
\hline 5A1P1P5FR & Parallel (AG) & $4.24 \mathrm{E}+09$ & 4.24 & 5A1T2L6F & Transverse (WG) & $4.28 \mathrm{E}+09$ & 4.28 \\
\hline 5A1P4P1F & Parallel (AG) & $4.21 \mathrm{E}+09$ & 4.21 & 5A1T3L2FR & Transverse (WG) & $4.27 \mathrm{E}+09$ & 4.27 \\
\hline 5A1P4P3F & Parallel (AG) & $4.2 \mathrm{E}+09$ & & 5A1T3L4F & Transverse (WG) & $4.25 \mathrm{E}+09$ & 4.25 \\
\hline 5A1P4P5F & Parallel (AG) & $4.2 \mathrm{E}+09$ & 4.20 & 5A1T3L6F & Transverse (WG) & $4.31 \mathrm{E}+09$ & 4.31 \\
\hline 5B3P1P1F & Parallel (AG) & $4.24 \mathrm{E}+09$ & 4.24 & 5B3T2L2FR & Transverse (WG) & $4.28 \mathrm{E}+09$ & 4.28 \\
\hline 5B3P1P3F & Parallel (AG) & $4.31 \mathrm{E}+09$ & 4.31 & 5B3T2L4F & Transverse (WG) & $4.25 \mathrm{E}+09$ & 4.25 \\
\hline 5B3P1P5F & Parallel (AG) & $4.29 \mathrm{E}+09$ & 4.29 & 5B3T2L6F & Transverse (WG) & $4.26 \mathrm{E}+09$ & 4.26 \\
\hline 5B3P4P1F & Parallel (AG) & $4.3 \mathrm{E}+09$ & 4.30 & 5B3T3L2F & Transverse (WG) & $4.25 \mathrm{E}+09$ & 4.25 \\
\hline 5B3P4P3F & Parallel (AG) & $4.34 \mathrm{E}+09$ & 4.34 & 5B3T3L4F & Transverse (WG) & $4.24 \mathrm{E}+09$ & 4.24 \\
\hline 5B3P4P5FR & Parallel (AG) & $4.29 \mathrm{E}+09$ & 4.29 & 5B3T3L6F & Transverse (WG) & $4.24 \mathrm{E}+09$ & 4.24 \\
\hline
\end{tabular}


Table A.9. Shear moduli (by fundamental frequency method) measured on flexural strength specimens in the torsional vibration mode (billet 116310) sorted by in-billet position

\begin{tabular}{|c|c|c|c|c|c|c|c|}
\hline \multirow{2}{*}{$\begin{array}{l}\text { Specimen } \\
\text { number }\end{array}$} & \multirow{2}{*}{$\begin{array}{c}\text { Grain } \\
\text { orientation }\end{array}$} & \multicolumn{2}{|c|}{ Shear modulus, G } & \multirow{2}{*}{$\begin{array}{c}\text { Specimen } \\
\text { number }\end{array}$} & \multirow{2}{*}{$\begin{array}{c}\text { Grain } \\
\text { orientation }\end{array}$} & \multicolumn{2}{|c|}{ Shear modulus, G } \\
\hline & & $\mathbf{P a}$ & GPa & & & $\mathbf{P a}$ & GPa \\
\hline 1A1P1P1F & Parallel (AG) & $4.12 \mathrm{E}+09$ & 4.12 & 5A1T2L2F & Transverse (WG) & $4.3 \mathrm{E}+09$ & 4.30 \\
\hline 1A1P1P3F & Parallel (AG) & $4.1 \mathrm{E}+09$ & 4.10 & 5A1T2L4F & Transverse (WG) & $4.29 \mathrm{E}+09$ & 4.29 \\
\hline 1A1P1P5F & Parallel (AG) & $4.19 \mathrm{E}+09$ & 4.19 & 5A1T2L6F & Transverse (WG) & $4.28 \mathrm{E}+09$ & 4.28 \\
\hline 1A1P4P1F & Parallel (AG) & $4.28 \mathrm{E}+09$ & 4.28 & 5A1T3L2FR & Transverse $(\mathrm{WG})$ & $4.27 \mathrm{E}+09$ & 4.27 \\
\hline 1A1P4P3F & Parallel (AG) & $4.3 \mathrm{E}+09$ & 4.30 & 5A1T3L4F & Transverse (WG) & $4.25 \mathrm{E}+09$ & 4.25 \\
\hline 1A1P4P5F & Parallel (AG) & $4.27 \mathrm{E}+09$ & 4.27 & 5A1T3L6F & Transverse $(\mathrm{WG})$ & $4.31 \mathrm{E}+09$ & 4.31 \\
\hline 1A4P1P1F & Parallel (AG) & $4.26 \mathrm{E}+09$ & 4.26 & 5B3T2L2FR & Transverse (WG) & $4.28 \mathrm{E}+09$ & 4.28 \\
\hline 1A4P1P3F & Parallel (AG) & $4.21 \mathrm{E}+09$ & 4.21 & 5B3T2L4F & Transverse (WG) & $4.25 \mathrm{E}+09$ & 4.25 \\
\hline 1A4P1P5F & Parallel (AG) & $4.13 \mathrm{E}+09$ & 4.13 & 5B3T2L6F & Transverse (WG) & $4.26 \mathrm{E}+09$ & 4.26 \\
\hline 1A4P4P1F & Parallel (AG) & $4.29 \mathrm{E}+09$ & 4.29 & 5B3T3L2F & Transverse (WG) & $4.25 \mathrm{E}+09$ & 4.25 \\
\hline 1A4P4P3F & Parallel (AG) & $4.23 \mathrm{E}+09$ & 4.23 & 5B3T3L4F & Transverse (WG) & $4.24 \mathrm{E}+09$ & 4.24 \\
\hline 1A4P4P5F & Parallel (AG) & $4.28 \mathrm{E}+09$ & 4.28 & 5B3T3L6F & Transverse (WG) & $4.24 \mathrm{E}+09$ & 4.24 \\
\hline 1B2P1PIF & Parallel (AG) & $4.16 \mathrm{E}+09$ & 4.16 & 5A1P1P1F & Parallel (AG) & $4.21 \mathrm{E}+09$ & 4.21 \\
\hline 1B2P1P3F & Parallel (AG) & $4.27 \mathrm{E}+09$ & 4.27 & 5A1P1P3F & Parallel (AG) & $4.23 \mathrm{E}+09$ & 4.23 \\
\hline 1B2P1P5F & Parallel (AG) & $4.09 \mathrm{E}+09$ & 4.09 & 5A1P1P5FR & Parallel (AG) & $4.24 \mathrm{E}+09$ & 4.24 \\
\hline 1B2P4P1F & Parallel (AG) & $4.11 \mathrm{E}+09$ & 4.11 & 5A1P4P1F & Parallel (AG) & $4.21 \mathrm{E}+09$ & 4.21 \\
\hline 1B2P4P3F & Parallel (AG) & $4.12 \mathrm{E}+09$ & 4.12 & 5A1P4P3F & Parallel (AG) & $4.2 \mathrm{E}+09$ & 4.20 \\
\hline 1B2P4P5F & Parallel (AG) & $4.12 \mathrm{E}+09$ & 4.12 & 5A1P4P5F & Parallel (AG) & $4.2 \mathrm{E}+09$ & 4.20 \\
\hline 1B3P1P1F & Parallel (AG) & $4.3 \mathrm{E}+09$ & 4.30 & 5B3P1P1F & Parallel (AG) & $4.24 \mathrm{E}+09$ & 4.24 \\
\hline 1B3P1P3F & Parallel (AG) & $4.37 \mathrm{E}+09$ & 4.37 & 5B3P1P3F & Parallel (AG) & $4.31 \mathrm{E}+09$ & 4.31 \\
\hline 1B3P1P5F & Parallel (AG) & $4.36 \mathrm{E}+09$ & 4.36 & 5B3P1P5F & Parallel (AG) & $4.29 \mathrm{E}+09$ & 4.29 \\
\hline 1B3P4P1F & Parallel (AG) & $4.07 \mathrm{E}+09$ & 4.07 & 5B3P4P1F & Parallel (AG) & $4.3 \mathrm{E}+09$ & 4.30 \\
\hline 1B3P4P3F & Parallel (AG) & $4.15 \mathrm{E}+09$ & 4.15 & 5B3P4P3F & Parallel (AG) & $4.34 \mathrm{E}+09$ & 4.34 \\
\hline 1B3P4P5F & Parallel (AG) & $4.2 \mathrm{E}+09$ & 4.20 & 5B3P4P5FR & Parallel (AG) & $4.29 \mathrm{E}+09$ & 4.29 \\
\hline 1B2T2L2F & Transverse (WG) & $4.17 \mathrm{E}+09$ & 4.17 & & & & \\
\hline 1B2T2L4F & Transverse (WG) & $4.11 \mathrm{E}+09$ & 4.11 & & & & \\
\hline 1B2T2L6F & Transverse (WG) & $4.3 \mathrm{E}+09$ & 4.30 & & & & \\
\hline 1B2T3L2F & Transverse (WG) & $4.29 \mathrm{E}+09$ & 4.29 & & & & \\
\hline 1B2T3L4F & Transverse (WG) & $4.21 \mathrm{E}+09$ & 4.21 & & & & \\
\hline 1B2T3L6F & Transverse (WG) & $4.11 \mathrm{E}+09$ & 4.11 & & & & \\
\hline
\end{tabular}


Table A.9. Shear moduli (by fundamental frequency method) measured on flexural strength specimens in the torsional vibration mode (billet 116310) sorted by in-billet position (continued)

\begin{tabular}{|c|c|c|c|c|c|c|c|}
\hline \multirow{2}{*}{$\begin{array}{c}\text { Specimen } \\
\text { number }\end{array}$} & \multirow{2}{*}{$\begin{array}{c}\text { Grain } \\
\text { orientation }\end{array}$} & \multicolumn{2}{|c|}{ Shear modulus, G } & \multirow{2}{*}{$\begin{array}{c}\text { Specimen } \\
\text { number }\end{array}$} & \multirow{2}{*}{$\begin{array}{c}\text { Grain } \\
\text { orientation }\end{array}$} & \multicolumn{2}{|c|}{ Shear modulus, G } \\
\hline & & $\mathbf{P a}$ & GPa & & & $\mathbf{P a}$ & GPa \\
\hline 1B3T2L2F & Transverse (WG) & $4.34 \mathrm{E}+09$ & 4.34 & & & & \\
\hline 1B3T2L4F & Transverse (WG) & $4.15 \mathrm{E}+09$ & 4.15 & & & & \\
\hline 1B3T2L6F & Transverse (WG) & $4.28 \mathrm{E}+09$ & 4.28 & & & & \\
\hline 1B3T3L2F & Transverse (WG) & $4.22 \mathrm{E}+09$ & 4.22 & & & & \\
\hline 1B3T3L4F & Transverse (WG) & $4.27 \mathrm{E}+09$ & 4.27 & & & & \\
\hline 1B3T3L6F & Transverse (WG) & $4.28 \mathrm{E}+09$ & 4.28 & & & & \\
\hline 1A1T2L2F & Transverse (WG) & $4.17 \mathrm{E}+09$ & 4.17 & & & & \\
\hline 1A1T2L4F & Transverse (WG) & $4.19 \mathrm{E}+09$ & 4.19 & & & & \\
\hline 1A1T2L6F & Transverse (WG) & $4.22 \mathrm{E}+09$ & 4.22 & & & & \\
\hline 1AIT3L2F & Transverse (WG) & $4.25 \mathrm{E}+09$ & 4.25 & & & & \\
\hline 1AIT3L4F & Transverse (WG) & $4.31 \mathrm{E}+09$ & 4.31 & & & & \\
\hline 1AIT3L6F & Transverse (WG) & $4.28 \mathrm{E}+09$ & 4.28 & & & & \\
\hline 1A4T3L2F & Transverse (WG) & $4.15 \mathrm{E}+09$ & 4.15 & & & & \\
\hline 1A4T3L4F & Transverse (WG) & $4.11 \mathrm{E}+09$ & 4.11 & & & & \\
\hline 1A4T3L6F & Transverse (WG) & $4.28 \mathrm{E}+09$ & 4.28 & & & & \\
\hline 1A4T2L2F & Transverse (WG) & $4.14 \mathrm{E}+09$ & 4.14 & & & & \\
\hline 1A4T2L4F & Transverse (WG) & $4.15 \mathrm{E}+09$ & 4.15 & & & & \\
\hline 1A4T2L6F & Transverse (WG) & $4.15 \mathrm{E}+09$ & 4.15 & & & & \\
\hline
\end{tabular}


Table A.10. 2114 graphite Poisson's ratio (by fundamental frequency method) measured on compressive strength specimen in the "Upright" and "Flat" test orientations

\begin{tabular}{|c|c|c|c|c|c|c|c|}
\hline \multirow[t]{2}{*}{$\begin{array}{c}\text { Specimen } \\
\text { number }\end{array}$} & \multirow[t]{2}{*}{$\begin{array}{c}\text { Grain } \\
\text { orientation }\end{array}$} & \multirow[t]{2}{*}{$\begin{array}{c}\begin{array}{c}\text { Upright- } \\
\text { Young's } \\
\text { modulus E }\end{array} \\
\text { GPa }\end{array}$} & \multirow[t]{2}{*}{$\begin{array}{c}\begin{array}{c}\text { Shear } \\
\text { modulus, } \\
\text { g }\end{array} \\
\text { GPa }\end{array}$} & \multirow[t]{2}{*}{$\begin{array}{c}\text { (Upright) } \\
\text { Poisson's } \\
\text { ratio, } \mu\end{array}$} & \multirow[t]{2}{*}{\begin{tabular}{|c|c}
$\begin{array}{c}\text { Flat- } \\
\text { Young's } \\
\text { modulus, E }\end{array}$ \\
GPa
\end{tabular}} & \multirow[t]{2}{*}{$\begin{array}{c}\begin{array}{c}\text { Shear } \\
\text { modulus, } \\
\text { g }\end{array} \\
\text { GPa }\end{array}$} & \multirow[t]{2}{*}{$\begin{array}{c}\text { (Flat) } \\
\text { Poisson's } \\
\text { ratio, } \mu\end{array}$} \\
\hline & & & & & & & \\
\hline 1A1P1P1F & Parallel (AG) & 9.63 & 4.12 & 0.17 & 9.48 & 4.12 & 0.15 \\
\hline 1A1P1P3F & Parallel (AG) & 9.75 & 4.10 & 0.19 & 9.58 & 4.10 & 0.17 \\
\hline 1A1P1P5F & Parallel (AG) & 9.85 & 4.19 & 0.18 & 9.74 & 4.19 & 0.16 \\
\hline 1A1T2L2F & Transverse (WG) & 10.35 & 4.17 & 0.24 & 10.14 & 4.17 & 0.22 \\
\hline 1A1T2L4F & Transverse (WG) & 10.16 & 4.19 & 0.21 & 10.01 & 4.19 & 0.19 \\
\hline 1A1T2L6F & Transverse (WG) & 10.08 & 4.22 & 0.19 & 9.94 & 4.22 & 0.18 \\
\hline 1AIT3L2F & Transverse (WG) & 10.47 & 4.25 & 0.23 & 10.28 & 4.25 & 0.21 \\
\hline 1AIT3L4F & Transverse (WG) & 10.59 & 4.31 & 0.23 & 10.41 & 4.31 & 0.21 \\
\hline 1AIT3L6F & Transverse (WG) & 10.51 & 4.28 & 0.23 & 10.28 & 4.28 & 0.20 \\
\hline 1A1P4P1F & Parallel (AG) & 9.93 & 4.28 & 0.16 & 9.78 & 4.28 & 0.14 \\
\hline 1A1P4P3F & Parallel (AG) & 10.08 & 4.30 & 0.17 & 9.90 & 4.30 & 0.15 \\
\hline 1A1P4P5F & Parallel (AG) & 10.18 & 4.27 & 0.19 & 10.00 & 4.27 & 0.17 \\
\hline 1A4P1P1F & Parallel (AG) & 10.36 & 4.26 & 0.22 & 10.19 & 4.26 & 0.20 \\
\hline 1A4P1P3F & Parallel (AG) & 10.31 & 4.21 & 0.22 & 10.11 & 4.21 & 0.20 \\
\hline 1A4P1P5F & Parallel (AG) & 10.31 & 4.13 & 0.25 & 10.10 & 4.13 & 0.22 \\
\hline 1A4P4P1F & Parallel (AG) & 10.30 & 4.29 & 0.20 & 10.14 & 4.29 & 0.18 \\
\hline 1A4P4P3F & Parallel (AG) & 10.38 & 4.23 & 0.23 & 10.19 & 4.23 & 0.20 \\
\hline 1A4P4P5F & Parallel (AG) & 10.37 & 4.28 & 0.21 & 10.18 & 4.28 & 0.19 \\
\hline 1A4T3L2F & Transverse (WG) & 9.59 & 4.15 & 0.16 & 9.57 & 4.15 & 0.15 \\
\hline 1A4T3L4F & Transverse (WG) & 9.65 & 4.11 & 0.17 & 9.50 & 4.11 & 0.15 \\
\hline 1A4T3L6F & Transverse (WG) & 10.04 & 4.28 & 0.17 & 9.90 & 4.28 & 0.16 \\
\hline 1A4T2L2F & Transverse (WG) & 9.67 & 4.14 & 0.17 & 9.52 & 4.14 & 0.15 \\
\hline 1A4T2L4F & Transverse (WG) & 9.57 & 4.15 & 0.15 & 9.43 & 4.15 & 0.14 \\
\hline 1A4T2L6F & Transverse (WG) & 9.53 & 4.15 & 0.15 & 9.37 & 4.15 & 0.13 \\
\hline 1B2P1PIF & Parallel (AG) & 9.77 & 4.16 & 0.18 & 9.61 & 4.16 & 0.15 \\
\hline 1B2P1P3F & Parallel (AG) & 10.04 & 4.27 & 0.18 & 9.85 & 4.27 & 0.15 \\
\hline 1B2P1P5F & Parallel (AG) & 9.48 & 4.09 & 0.16 & 9.36 & 4.09 & 0.14 \\
\hline 1B2P4P1F & Parallel (AG) & 9.68 & 4.11 & 0.18 & 9.52 & 4.11 & 0.16 \\
\hline 1B2P4P3F & Parallel (AG) & 9.61 & 4.12 & 0.17 & 9.45 & 4.12 & 0.15 \\
\hline 1B2P4P5F & Parallel (AG) & 9.72 & 4.12 & 0.18 & 9.55 & 4.12 & 0.16 \\
\hline
\end{tabular}


Table A.10. 2114 graphite Poisson's ratio (by fundamental frequency method) measured on compressive strength specimen in the "Upright" and "Flat" test orientations (continued)

\begin{tabular}{|c|c|c|c|c|c|c|c|}
\hline \multirow[t]{2}{*}{$\begin{array}{c}\text { Specimen } \\
\text { number }\end{array}$} & \multirow[t]{2}{*}{$\begin{array}{c}\text { Grain } \\
\text { orientation }\end{array}$} & \multirow{2}{*}{$\begin{array}{c}\begin{array}{c}\text { Upright- } \\
\text { Young's } \\
\text { modulus E }\end{array} \\
\text { GPa }\end{array}$} & \multirow{2}{*}{$\begin{array}{c}\begin{array}{c}\text { Shear } \\
\text { modulus, } \\
\text { g }\end{array} \\
\text { GPa }\end{array}$} & \multirow[t]{2}{*}{$\begin{array}{c}\text { (Upright) } \\
\text { Poisson's } \\
\text { ratio, } \boldsymbol{\mu}\end{array}$} & \multirow{2}{*}{$\begin{array}{c}\text { Flat- } \\
\begin{array}{c}\text { Young's } \\
\text { modulus, E }\end{array} \\
\text { GPa }\end{array}$} & \multirow{2}{*}{$\begin{array}{c}\begin{array}{c}\text { Shear } \\
\text { modulus, } \\
\text { g }\end{array} \\
\text { GPa }\end{array}$} & \multirow[t]{2}{*}{$\begin{array}{c}\text { (Flat) } \\
\text { Poisson' } \\
\text { ratio, } \mu\end{array}$} \\
\hline & & & & & & & \\
\hline 1B2T2L2F & Transverse (WG) & 10.37 & 4.17 & 0.24 & 10.17 & 4.17 & 0.22 \\
\hline 1B2T2L4F & Transverse (WG) & 10.30 & 4.11 & 0.25 & 10.11 & 4.11 & 0.23 \\
\hline 1B2T2L6F & Transverse (WG) & 10.40 & 4.30 & 0.21 & 10.22 & 4.30 & 0.19 \\
\hline 1B2T3L2F & Transverse (WG) & 10.53 & 4.29 & 0.23 & 10.33 & 4.29 & 0.20 \\
\hline 1B2T3L4F & Transverse (WG) & 10.37 & 4.21 & 0.23 & 10.15 & 4.21 & 0.21 \\
\hline 1B2T3L6F & Transverse (WG) & 10.22 & 4.11 & 0.24 & 10.04 & 4.11 & 0.22 \\
\hline 1B3P1P1F & Parallel (AG) & 9.97 & 4.30 & 0.16 & 9.85 & 4.30 & 0.15 \\
\hline 1B3P1P3F & Parallel (AG) & 10.11 & 4.37 & 0.16 & 9.98 & 4.37 & 0.14 \\
\hline 1B3P1P5F & Parallel (AG) & 10.32 & 4.36 & 0.18 & 10.17 & 4.36 & 0.17 \\
\hline 1B3P4P1F & Parallel (AG) & 9.50 & 4.07 & 0.17 & 9.34 & 4.07 & 0.15 \\
\hline 1B3P4P3F & Parallel (AG) & 9.68 & 4.15 & 0.17 & 9.53 & 4.15 & 0.15 \\
\hline 1B3P4P5F & Parallel (AG) & 9.90 & 4.20 & 0.18 & 9.73 & 4.20 & 0.16 \\
\hline 1B3T2L2F & Transverse (WG) & 10.92 & 4.34 & 0.26 & 10.68 & 4.34 & 0.23 \\
\hline 1B3T2L4F & Transverse (WG) & 10.69 & 4.15 & 0.29 & 10.47 & 4.15 & 0.26 \\
\hline 1B3T2L6F & Transverse (WG) & 10.43 & 4.28 & 0.22 & 10.25 & 4.28 & 0.20 \\
\hline 1B3T3L2F & Transverse (WG) & 10.46 & 4.22 & 0.24 & 10.26 & 4.22 & 0.22 \\
\hline 1B3T3L4F & Transverse (WG) & 10.69 & 4.27 & 0.25 & 10.48 & 4.27 & 0.23 \\
\hline 1B3T3L6F & Transverse (WG) & 10.77 & 4.28 & 0.26 & 10.54 & 4.28 & 0.23 \\
\hline 5A1P1P1F & Parallel (AG) & 10.15 & 4.21 & 0.21 & 9.98 & 4.21 & 0.19 \\
\hline 5A1P1P3F & Parallel (AG) & 10.21 & 4.23 & 0.21 & 10.03 & 4.23 & 0.19 \\
\hline 5A1P1P5FR & Parallel (AG) & 10.27 & 4.24 & 0.21 & 10.09 & 4.24 & 0.19 \\
\hline 5A1P4P1F & Parallel (AG) & 10.09 & 4.21 & 0.20 & 9.88 & 4.21 & 0.17 \\
\hline 5A1P4P3F & Parallel (AG) & 10.09 & 4.20 & 0.20 & 9.92 & 4.20 & 0.18 \\
\hline 5A1P4P5F & Parallel (AG) & 10.04 & 4.20 & 0.20 & 9.87 & 4.20 & 0.18 \\
\hline 5A1T2L2F & Transverse (WG) & 10.61 & 4.30 & 0.23 & 10.41 & 4.30 & 0.21 \\
\hline 5A1T2L4F & Transverse (WG) & 10.60 & 4.29 & 0.24 & 10.44 & 4.29 & 0.22 \\
\hline 5A1T2L6F & Transverse (WG) & 10.51 & 4.28 & 0.23 & 10.34 & 4.28 & 0.21 \\
\hline 5A1T3L2FR & Transverse (WG) & 10.52 & 4.27 & 0.23 & 10.32 & 4.27 & 0.21 \\
\hline
\end{tabular}


Table A.10. 2114 graphite Poisson's ratio (by fundamental frequency method) measured on compressive strength specimen in the "Upright" and "Flat" test orientations (continued)

\begin{tabular}{|c|c|c|c|c|c|c|c|}
\hline \multirow[t]{2}{*}{$\begin{array}{l}\text { Specimen } \\
\text { number }\end{array}$} & \multirow[t]{2}{*}{$\begin{array}{c}\text { Grain } \\
\text { orientation }\end{array}$} & \multirow{2}{*}{$\begin{array}{c}\begin{array}{c}\text { Upright- } \\
\text { Young's } \\
\text { modulus E }\end{array} \\
\text { GPa }\end{array}$} & \multirow{2}{*}{$\begin{array}{c}\begin{array}{c}\text { Shear } \\
\text { modulus, } \\
\text { g }\end{array} \\
\text { GPa }\end{array}$} & \multirow{2}{*}{$\begin{array}{c}\text { (Upright) } \\
\text { Poisson's } \\
\text { ratio, } \boldsymbol{\mu}\end{array}$} & \multirow{2}{*}{$\begin{array}{c}\begin{array}{c}\text { Flat- } \\
\text { Young's } \\
\text { modulus, E }\end{array} \\
\text { GPa }\end{array}$} & \multirow{2}{*}{$\begin{array}{c}\begin{array}{c}\text { Shear } \\
\text { modulus, } \\
\text { g }\end{array} \\
\text { GPa }\end{array}$} & \multirow[t]{2}{*}{$\begin{array}{c}\text { (Flat) } \\
\text { Poisson's } \\
\text { ratio, } \mu\end{array}$} \\
\hline & & & & & & & \\
\hline 5A1T3L4F & Transverse (WG) & 10.53 & 4.25 & 0.24 & 10.35 & 4.25 & 0.22 \\
\hline 5A1T3L6F & Transverse (WG) & 10.69 & 4.31 & 0.24 & 10.47 & 4.31 & 0.22 \\
\hline 5B3P1P1F & Parallel (AG) & 10.48 & 4.24 & 0.23 & 10.29 & 4.24 & 0.21 \\
\hline 5B3P1P3F & Parallel (AG) & 10.49 & 4.31 & 0.22 & 10.32 & 4.31 & 0.20 \\
\hline 5B3P1P5F & Parallel (AG) & 10.47 & 4.29 & 0.22 & 10.29 & 4.29 & 0.20 \\
\hline 5B3P4P1F & Parallel (AG) & 10.62 & 4.30 & 0.23 & 10.40 & 4.30 & 0.21 \\
\hline 5B3P4P3F & Parallel (AG) & 10.61 & 4.34 & 0.22 & 10.41 & 4.34 & 0.20 \\
\hline 5B3P4P5FR & Parallel (AG) & 10.46 & 4.29 & 0.22 & 10.31 & 4.29 & 0.20 \\
\hline 5B3T2L2FR & Transverse (WG) & 10.37 & 4.28 & 0.21 & 10.18 & 4.28 & 0.19 \\
\hline 5B3T2L4F & Transverse (WG) & 10.27 & 4.25 & 0.21 & 10.08 & 4.25 & 0.19 \\
\hline 5B3T2L6F & Transverse (WG) & 10.32 & 4.26 & 0.21 & 10.14 & 4.26 & 0.19 \\
\hline 5B3T3L2F & Transverse (WG) & 10.23 & 4.25 & 0.20 & 10.06 & 4.25 & 0.18 \\
\hline 5B3T3L4F & Transverse (WG) & 10.37 & 4.24 & 0.22 & 10.10 & 4.24 & 0.19 \\
\hline 5B3T3L6F & Transverse (WG) & 10.25 & 4.24 & 0.21 & 10.06 & 4.24 & 0.19 \\
\hline
\end{tabular}


Table A.11. Graphite grade 2114 Poisson's ratio (by fundamental frequency method) measured on compressive strength specimen in the "Flat" test orientations sorted by filler particle (grain) orientation

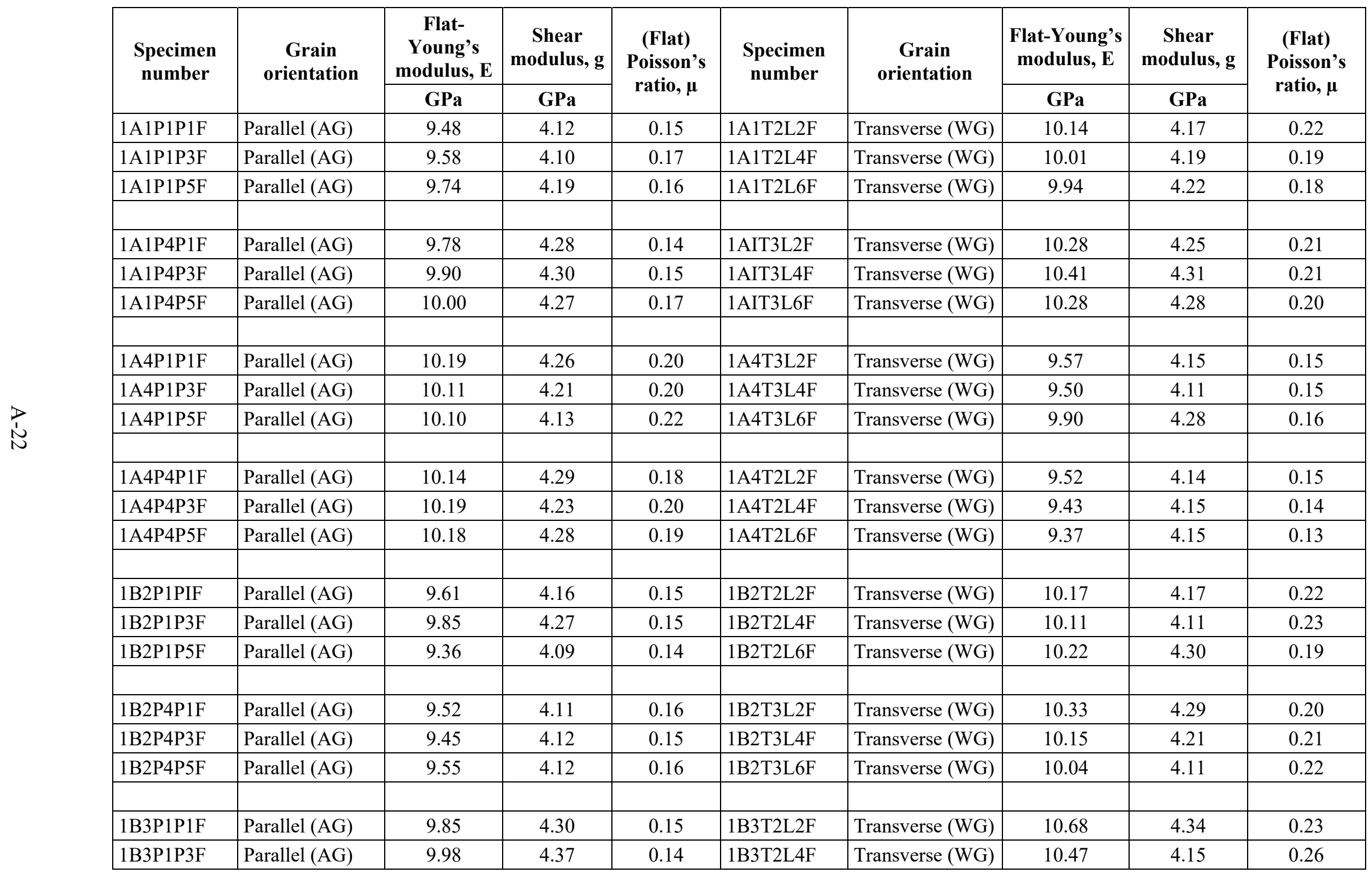


Table A.11. Graphite grade 2114 Poisson's ratio (by fundamental frequency method) measured on compressive strength specimen in the "Flat" test orientations sorted by filler particle (grain) orientation (continued)

\begin{tabular}{|c|c|c|c|c|c|c|c|c|c|}
\hline \multirow[t]{2}{*}{$\begin{array}{l}\text { Specimen } \\
\text { number }\end{array}$} & \multirow[t]{2}{*}{$\begin{array}{c}\text { Grain } \\
\text { orientation }\end{array}$} & \multirow{2}{*}{$\begin{array}{c}\begin{array}{c}\text { Flat- } \\
\text { Young's } \\
\text { modulus, E }\end{array} \\
\text { GPa }\end{array}$} & \multirow{2}{*}{\begin{tabular}{c|}
$\begin{array}{c}\text { Shear } \\
\text { modulus, g }\end{array}$ \\
GPa
\end{tabular}} & \multirow[t]{2}{*}{$\begin{array}{l}\text { (Flat) } \\
\text { Poisson's } \\
\text { ratio, } \mu\end{array}$} & \multirow[t]{2}{*}{$\begin{array}{l}\text { Specimen } \\
\text { number }\end{array}$} & \multirow[t]{2}{*}{$\begin{array}{c}\text { Grain } \\
\text { orientation }\end{array}$} & \multirow{2}{*}{$\begin{array}{c}\begin{array}{c}\text { Flat-Young's } \\
\text { modulus, E }\end{array} \\
\text { GPa }\end{array}$} & \multirow{2}{*}{$\begin{array}{c}\begin{array}{c}\text { Shear } \\
\text { modulus, g }\end{array} \\
\text { GPa }\end{array}$} & \multirow[t]{2}{*}{$\begin{array}{l}\text { (Flat) } \\
\text { Poisson's } \\
\text { ratio, } \mu\end{array}$} \\
\hline & & & & & & & & & \\
\hline 1B3P4P1F & Parallel (AG) & 9.34 & 4.07 & 0.15 & 1B3T3L2F & Transverse (WG) & 10.26 & 4.22 & 0.22 \\
\hline 1B3P4P3F & Parallel (AG) & 9.53 & 4.15 & 0.15 & 1B3T3L4F & Transverse (WG) & 10.48 & 4.27 & 0.23 \\
\hline 5A1P1P1F & Parallel (AG) & 9.98 & 4.21 & 0.19 & 5A1T2L2F & Transverse (WG) & 10.41 & 4.30 & 0.21 \\
\hline 5A1P1P3F & Parallel (AG) & 10.03 & 4.23 & 0.19 & 5A1T2L4F & Transverse (WG) & 10.44 & 4.29 & 0.22 \\
\hline 5A1P1P5FR & Parallel (AG) & 10.09 & 4.24 & 0.19 & 5A1T2L6F & Transverse (WG) & 10.34 & 4.28 & 0.21 \\
\hline & & & & & & Twongros (WVC) & & & \\
\hline 5A1P4P1F & Parallel (AG) & 9.88 & 4.21 & 0.17 & 5A1T3L2FR & Transverse (WG) & 10.32 & 4.27 & 0.21 \\
\hline 5B3P1P3F & Parallel (AG) & 10.32 & 4.31 & 0.20 & 5B3T2L4F & Transverse (WG) & 10.08 & 4.25 & 0.19 \\
\hline 5B3P1P5F & Parallel (AG) & 10.29 & 4.29 & 0.20 & 5B3T2L6F & Transverse (WG) & 10.14 & 4.26 & 0.19 \\
\hline 5B3P4P1F & Parallel (AG) & 10.40 & 4.30 & 0.21 & 5B3T3L2F & Transverse (WG) & 10.06 & 4.25 & 0.18 \\
\hline 5B3P4P3F & Parallel (AG) & 10.41 & 4.34 & 0.20 & 5B3T3L4F & Transverse (WG) & 10.10 & 4.24 & 0.19 \\
\hline 5B3P4P5FR & Parallel (AG) & 10.31 & 4.29 & 0.20 & 5B3T3L6F & Transverse (WG) & 10.06 & 4.24 & 0.19 \\
\hline
\end{tabular}


Table A.12. Graphite grade 2114 Poisson's ratio (by fundamental frequency method) measured on compressive strength specimen in the "Flat" test orientations sorted by in-billet location (billet end = specimen numbers beginning with 1: billet center = specimen numbers beginning with 5)

(With-grain specimens only)

\begin{tabular}{|c|c|c|c|c|c|c|c|c|c|}
\hline \multirow[t]{2}{*}{$\begin{array}{c}\text { Specimen } \\
\text { number }\end{array}$} & \multirow[t]{2}{*}{$\begin{array}{c}\text { Grain } \\
\text { orientation }\end{array}$} & \multirow{2}{*}{$\begin{array}{c}\begin{array}{c}\text { Flat- } \\
\text { Young's } \\
\text { modulus, } \\
\text { E }\end{array} \\
\text { GPa } \\
\end{array}$} & \multirow{2}{*}{\begin{tabular}{|c|}
$\begin{array}{c}\text { Shear } \\
\text { modulus, g }\end{array}$ \\
GPa \\
\end{tabular}} & \multirow[t]{2}{*}{$\begin{array}{l}\text { (Flat) } \\
\text { Poisson's } \\
\text { ratio, } \mu\end{array}$} & \multirow[t]{2}{*}{$\begin{array}{l}\text { Specimen } \\
\text { number }\end{array}$} & \multirow[t]{2}{*}{$\begin{array}{c}\text { Grain } \\
\text { orientation }\end{array}$} & \multirow{2}{*}{\begin{tabular}{|c}
$\begin{array}{c}\text { Flat- } \\
\text { Young's } \\
\text { modulus, E }\end{array}$ \\
GPa \\
\end{tabular}} & \multirow{2}{*}{\begin{tabular}{|c|}
$\begin{array}{c}\text { Shear } \\
\text { modulus, g }\end{array}$ \\
GPa \\
\end{tabular}} & \multirow[t]{2}{*}{$\begin{array}{c}\text { (Flat) } \\
\text { Poisson's } \\
\text { ratio, } \mu\end{array}$} \\
\hline & & & & & & & & & \\
\hline 1A1T2L2F & Transverse (WG) & 10.14 & 4.17 & 0.22 & 5A1T2L2F & Transverse (WG) & 10.41 & 4.30 & 0.21 \\
\hline 1A1T2L4F & Transverse (WG) & 10.01 & 4.19 & 0.19 & 5A1T2L4F & Transverse (WG) & 10.44 & 4.29 & 0.22 \\
\hline 1A1T2L6F & Transverse (WG) & 9.94 & 4.22 & 0.18 & 5A1T2L6F & Transverse (WG) & 10.34 & 4.28 & 0.21 \\
\hline 1AIT3L2F & Transverse (WG) & 10.28 & 4.25 & 0.21 & 5A1T3L2FR & Transverse (WG) & 10.32 & 4.27 & 0.21 \\
\hline 1AIT3L4F & Transverse (WG) & 10.41 & 4.31 & 0.21 & 5A1T3L4F & Transverse (WG) & 10.35 & 4.25 & 0.22 \\
\hline 1AIT3L6F & Transverse (WG) & 10.28 & 4.28 & 0.20 & 5A1T3L6F & Transverse (WG) & 10.47 & 4.31 & 0.22 \\
\hline 1A4T3L2F & Transverse (WG) & 9.57 & 4.15 & 0.15 & 5B3T2L2FR & Transverse (WG) & 10.18 & 4.28 & 0.19 \\
\hline 1A4T3L4F & Transverse (WG) & 9.50 & 4.11 & 0.15 & 5B3T2L4F & Transverse (WG) & 10.08 & 4.25 & 0.19 \\
\hline 1A4T3L6F & Transverse (WG) & 9.90 & 4.28 & 0.16 & 5B3T2L6F & Transverse (WG) & 10.14 & 4.26 & 0.19 \\
\hline 1A4T2L2F & Transverse (WG) & 9.52 & 4.14 & 0.15 & 5B3T3L2F & Transverse (WG) & 10.06 & 4.25 & 0.18 \\
\hline 1A4T2L4F & Transverse (WG) & 9.43 & 4.15 & 0.14 & 5B3T3L4F & Transverse (WG) & 10.10 & 4.24 & 0.19 \\
\hline 1A4T2L6F & Transverse (WG) & 9.37 & 4.15 & 0.13 & 5B3T3L6F & Transverse (WG) & 10.06 & 4.24 & 0.19 \\
\hline 1B2T2L2F & Transverse (WG) & 10.17 & 4.17 & 0.22 & & & & & \\
\hline 1B2T2L4F & Transverse (WG) & 10.11 & 4.11 & 0.23 & & & & & \\
\hline 1B2T2L6F & Transverse (WG) & 10.22 & 4.30 & 0.19 & & & & & \\
\hline 1B2T3L2F & Transverse (WG) & 10.33 & 4.29 & 0.20 & & & & & \\
\hline 1B2T3L4F & Transverse (WG) & 10.15 & 4.21 & 0.21 & & & & & \\
\hline 1B2T3L6F & Transverse (WG) & 10.04 & 4.11 & 0.22 & & & & & \\
\hline
\end{tabular}


Table A.12. Graphite grade 2114 Poisson's ratio (by fundamental frequency method) measured on compressive strength specimen in the "Flat" test orientations sorted by in-billet location (billet end = specimen numbers beginning with 1: billet center = specimen numbers beginning with 5) (With-grain specimens only) (continued)

\begin{tabular}{|c|c|c|c|c|c|c|c|c|c|}
\hline \multirow[t]{2}{*}{$\begin{array}{c}\text { Specimen } \\
\text { number }\end{array}$} & \multirow[t]{2}{*}{$\begin{array}{c}\text { Grain } \\
\text { orientation }\end{array}$} & $\begin{array}{c}\text { Flat- } \\
\text { Young's } \\
\text { modulus, } \\
\text { E }\end{array}$ & $\begin{array}{c}\text { Shear } \\
\text { modulus, g }\end{array}$ & \multirow[t]{2}{*}{$\begin{array}{c}\text { (Flat) } \\
\text { Poisson's } \\
\text { ratio, } \mu\end{array}$} & \multirow[t]{2}{*}{$\begin{array}{l}\text { Specimen } \\
\text { number }\end{array}$} & \multirow[t]{2}{*}{$\begin{array}{c}\text { Grain } \\
\text { orientation }\end{array}$} & $\begin{array}{c}\text { Flat- } \\
\text { Young's } \\
\text { modulus, E }\end{array}$ & $\begin{array}{c}\text { Shear } \\
\text { modulus, g }\end{array}$ & \multirow[t]{2}{*}{$\begin{array}{l}\text { (Flat) } \\
\text { Poisson's } \\
\text { ratio, } \mu\end{array}$} \\
\hline & & GPa & GPa & & & & GPa & GPa & \\
\hline 1B3T2L2F & Transverse (WG) & 10.68 & 4.34 & 0.23 & & & & & \\
\hline 1B3T2L4F & Transverse (WG) & 10.47 & 4.15 & 0.26 & & & & & \\
\hline 1B3T2L6F & Transverse (WG) & 10.25 & 4.28 & 0.20 & & & & & \\
\hline 1B3T3L2F & Transverse (WG) & 10.26 & 4.22 & 0.22 & & & & & \\
\hline 1B3T3L4F & Transverse (WG) & 10.48 & 4.27 & 0.23 & & & & & \\
\hline 1B3T3L6F & Transverse (WG) & 10.54 & 4.28 & 0.23 & & & & & \\
\hline
\end{tabular}


Table A.13. Sonic velocity (TOF) derived elastic constants for graphite grade 2114 billet 116310

\begin{tabular}{|c|c|c|c|c|c|c|c|c|}
\hline \multirow{4}{*}{$\begin{array}{l}\text { Specimen } \\
\text { number }\end{array}$} & \multirow{4}{*}{ Grain orientation } & \multirow{4}{*}{$\begin{array}{c}\text { Density, } \rho \\
\left(\mathbf{K g} / \mathbf{m}^{3}\right)\end{array}$} & \multirow{2}{*}{\multicolumn{2}{|c|}{ Sonic velocities, $\cup[\mathrm{m} / \mathrm{s}]$}} & \multicolumn{4}{|c|}{ ELASTIC CONSTANTS } \\
\hline & & & & & \multirow{2}{*}{$\begin{array}{c}\text { Elastic } \\
\text { modulus, }[\mathrm{Pa}]\end{array}$} & \multirow{2}{*}{$\begin{array}{c}\text { Shear } \\
\text { modulus, }[\mathrm{Pa}]\end{array}$} & \multirow{2}{*}{ Poisson's ratio } & \multirow{2}{*}{$\begin{array}{l}\text { Poisson's corrected } \\
\text { elastic modulus, }[\mathrm{Pa}]\end{array}$} \\
\hline & & & & Average & & & & \\
\hline & & & Longitudinal & $\begin{array}{c}\text { shear } \\
\text { velocity }\end{array}$ & E $\rho \cup 1^{2}$ & Gpus ${ }^{2}$ & $\begin{array}{c}\mu=\left(1-\left[2\left(U_{s} / U_{l}\right)^{2}\right]\right) / \\
\left(2-\left[2\left(U_{s} / U_{l}\right)^{2}\right]\right)\end{array}$ & $\begin{array}{c}\operatorname{E} \rho \mathrm{I}^{2}[(1+\mu)(1-2 \mu) / \\
(1-\mu)]\end{array}$ \\
\hline 1A1P1P1F & Parallel (AG) & 1816.3 & 2420.9 & $1.509 \mathrm{E}+03$ & $1.06448 \mathrm{E}+10$ & $4.137 \mathrm{E}+09$ & $1.822 \mathrm{E}-01$ & $9.781 \mathrm{E}+09$ \\
\hline 1A1P1P3F & Parallel (AG) & 1815.0 & 2423.5 & $1.508 \mathrm{E}+03$ & $1.06603 \mathrm{E}+10$ & $4.129 \mathrm{E}+09$ & $1.838 \mathrm{E}-01$ & $9.777 \mathrm{E}+09$ \\
\hline 1A1P1P5F & Parallel (AG) & 1818.9 & 2436.4 & $1.517 \mathrm{E}+03$ & $1.07973 \mathrm{E}+10$ & $4.187 \mathrm{E}+09$ & $1.832 \mathrm{E}-01$ & $9.909 \mathrm{E}+09$ \\
\hline 1A1T2L2F & Transverse (WG) & 1815.1 & 2440.5 & $1.526 \mathrm{E}+03$ & $1.08107 \mathrm{E}+10$ & $4.224 \mathrm{E}+09$ & $1.793 \mathrm{E}-01$ & $9.964 \mathrm{E}+09$ \\
\hline 1A1T2L4F & Transverse (WG) & 1815.9 & 2503.8 & $1.522 \mathrm{E}+03$ & $1.13835 \mathrm{E}+10$ & $4.204 \mathrm{E}+09$ & $2.072 \mathrm{E}-01$ & $1.015 \mathrm{E}+10$ \\
\hline 1A1T2L6F & Transverse (WG) & 1817.0 & 2489.7 & $1.535 \mathrm{E}+03$ & $1.12632 \mathrm{E}+10$ & $4.283 \mathrm{E}+09$ & $1.932 \mathrm{E}-01$ & $1.022 \mathrm{E}+10$ \\
\hline 1AIT3L2F & Transverse (WG) & 1816.3 & 2528.7 & $1.539 \mathrm{E}+03$ & $1.16143 \mathrm{E}+10$ & $4.302 \mathrm{E}+09$ & $2.058 \mathrm{E}-01$ & $1.038 \mathrm{E}+10$ \\
\hline 1AIT3L4F & Transverse (WG) & 1817.5 & 2538.5 & $1.530 \mathrm{E}+03$ & $1.17120 \mathrm{E}+10$ & $4.253 \mathrm{E}+09$ & $2.149 \mathrm{E}-01$ & $1.033 \mathrm{E}+10$ \\
\hline 1AIT3L6F & Transverse (WG) & 1820.0 & 2528.9 & $1.526 \mathrm{E}+03$ & $1.16390 \mathrm{E}+10$ & $4.241 \mathrm{E}+09$ & $2.134 \mathrm{E}-01$ & $1.029 \mathrm{E}+10$ \\
\hline 1A1P4P3F & Parallel (AG) & 1820.6 & 2461.0 & $1.528 \mathrm{E}+03$ & $1.10266 \mathrm{E}+10$ & $4.249 \mathrm{E}+09$ & $1.865 \mathrm{E}-01$ & $1.008 \mathrm{E}+10$ \\
\hline 1A1P4P5F & Parallel (AG) & 1822.4 & 2479.1 & $1.534 \mathrm{E}+03$ & $1.12001 \mathrm{E}+10$ & $4.288 \mathrm{E}+09$ & $1.899 \mathrm{E}-01$ & $1.020 \mathrm{E}+10$ \\
\hline 1A4P1P1F & Parallel (AG) & 1817.3 & 2498.0 & $1.546 \mathrm{E}+03$ & $1.13405 \mathrm{E}+10$ & $4.345 \mathrm{E}+09$ & $1.894 \mathrm{E}-01$ & $1.034 \mathrm{E}+10$ \\
\hline 1A4P1P3F & Parallel (AG) & 1817.3 & 2498.0 & $1.536 \mathrm{E}+03$ & $1.13403 \mathrm{E}+10$ & $4.287 \mathrm{E}+09$ & $1.962 \mathrm{E}-01$ & $1.025 \mathrm{E}+10$ \\
\hline 1A4P1P5F & Parallel (AG) & 1818.0 & 2496.5 & $1.523 \mathrm{E}+03$ & $1.13304 \mathrm{E}+10$ & $4.214 \mathrm{E}+09$ & $2.039 \mathrm{E}-01$ & $1.015 \mathrm{E}+10$ \\
\hline 1A4P4P1F & Parallel (AG) & 1816.3 & 2498.9 & $1.539 \mathrm{E}+03$ & $1.13415 \mathrm{E}+10$ & $4.299 \mathrm{E}+09$ & $1.948 \mathrm{E}-01$ & $1.027 \mathrm{E}+10$ \\
\hline 1A4P4P3F & Parallel (AG) & 1815.9 & 2510.8 & $1.537 \mathrm{E}+03$ & $1.14476 \mathrm{E}+10$ & $4.290 \mathrm{E}+09$ & $2.003 \mathrm{E}-01$ & $1.030 \mathrm{E}+10$ \\
\hline 1A4P4P5F & Parallel (AG) & 1818.3 & 2508.0 & $1.523 \mathrm{E}+03$ & $1.14373 \mathrm{E}+10$ & $4.220 \mathrm{E}+09$ & $2.077 \mathrm{E}-01$ & $1.019 \mathrm{E}+10$ \\
\hline 1A4T3L2F & Transverse (WG) & 1817.5 & 2429.2 & $1.506 \mathrm{E}+03$ & $1.07253 \mathrm{E}+10$ & $4.125 \mathrm{E}+09$ & $1.876 \mathrm{E}-01$ & $9.796 \mathrm{E}+09$ \\
\hline
\end{tabular}


Table A.13. Sonic velocity (TOF) derived elastic constants for graphite grade 2114 billet 116310 (continued)

\begin{tabular}{|c|c|c|c|c|c|c|c|c|}
\hline \multirow{3}{*}{$\begin{array}{l}\text { Specimen } \\
\text { number }\end{array}$} & \multirow{3}{*}{ Grain orientation } & \multirow{3}{*}{$\begin{array}{l}\text { Density, } \rho \\
\left(\mathrm{Kg} / \mathrm{m}^{3}\right)\end{array}$} & \multirow{2}{*}{\multicolumn{2}{|c|}{ Sonic velocities, $v[\mathrm{~m} / \mathrm{s}]$}} & \multicolumn{4}{|c|}{ ELASTIC CONSTANTS } \\
\hline & & & & & \multirow[b]{2}{*}{$\begin{array}{c}\text { Elastic } \\
\text { modulus, }[\mathrm{Pa}]\end{array}$} & \multirow[b]{2}{*}{$\begin{array}{c}\text { Shear } \\
\text { modulus, [Pa] }\end{array}$} & \multirow[b]{2}{*}{ Poisson's ratio } & \multirow[b]{2}{*}{$\begin{array}{l}\text { Poisson's corrected } \\
\text { elastic modulus, }[\mathrm{Pa}]\end{array}$} \\
\hline & & & Longitudinal & $\begin{array}{c}\text { Average } \\
\text { shear } \\
\text { velocity }\end{array}$ & & & & \\
\hline 1A4T3L4F & Transverse (WG) & 1816.2 & 2423.7 & $1.508 \mathrm{E}+03$ & $1.06690 \mathrm{E}+10$ & $4.129 \mathrm{E}+09$ & $1.844 \mathrm{E}-01$ & $9.780 \mathrm{E}+09$ \\
\hline 1A4T3L6F & Transverse (WG) & 1822.5 & 2476.3 & $1.526 \mathrm{E}+03$ & $1.11757 \mathrm{E}+10$ & $4.244 \mathrm{E}+09$ & $1.938 \mathrm{E}-01$ & $1.013 \mathrm{E}+10$ \\
\hline & & & & & & & & \\
\hline 1A41 LL $2 \mathrm{~F}$ & Transverse (WG) & 1818.9 & 2429.8 & $\begin{array}{r}1.511 \mathrm{E}+03 \\
.5015+02\end{array}$ & $1.07389 \mathrm{E}+10$ & 4.151E+09 & $1.849 \mathrm{E}-01$ & $9.838 \mathrm{E}+09$ \\
\hline 1A4T2L4F & Transverse (WG) & 1816.9 & 2412.9 & $1.504 \mathrm{E}+03$ & $1.05782 \mathrm{E}+10$ & $4.108 \mathrm{E}+09$ & $1.826 \mathrm{E}-01$ & $9.716 \mathrm{E}+09$ \\
\hline 1A4T2L6F & Transverse (WG) & 1816.4 & 2404.0 & $1.499 \mathrm{E}+03$ & $1.04971 \mathrm{E}+10$ & $4.079 \mathrm{E}+09$ & $1.822 \mathrm{E}-01$ & $9.644 \mathrm{E}+09$ \\
\hline 1B2P1PIF & Parallel (AG) & 1819.7 & 2440.2 & $1.517 \mathrm{E}+03$ & $1.08360 \mathrm{E}+10$ & $4.188 \mathrm{E}+09$ & $1.851 \mathrm{E}-01$ & $9.925 \mathrm{E}+09$ \\
\hline 1B2P1P3F & Parallel (AG) & 1827.1 & 2478.3 & $1.530 \mathrm{E}+03$ & $1.12216 \mathrm{E}+10$ & $4.279 \mathrm{E}+09$ & $1.918 \mathrm{E}-01$ & $1.020 \mathrm{E}+10$ \\
\hline 1B2P1P5F & Parallel (AG) & 1816.4 & 2411.8 & $1.515 \mathrm{E}+03$ & $1.05656 \mathrm{E}+10$ & $4.167 \mathrm{E}+09$ & $1.744 \mathrm{E}-01$ & $9.787 \mathrm{E}+09$ \\
\hline 1B2P4P1F & Parallel (AG) & 1820.1 & 2415.9 & $1.507 \mathrm{E}+03$ & $1.06233 \mathrm{E}+10$ & $4.133 \mathrm{E}+09$ & $1.816 \mathrm{E}-01$ & $9.767 \mathrm{E}+09$ \\
\hline 1B2P4P3F & Parallel (AG) & 1817.8 & 2409.9 & $1.509 \mathrm{E}+03$ & $1.05568 \mathrm{E}+10$ & $4.138 \mathrm{E}+09$ & $1.776 \mathrm{E}-01$ & $9.747 \mathrm{E}+09$ \\
\hline 1B2P4P5F & Parallel (AG) & 1819.4 & 2426.5 & $1.508 \mathrm{E}+03$ & $1.07130 \mathrm{E}+10$ & $4.138 \mathrm{E}+09$ & $1.854 \mathrm{E}-01$ & $9.809 \mathrm{E}+09$ \\
\hline 1B2T2L2F & Transverse (WG) & 1818.2 & 2505.7 & $1.533 \mathrm{E}+03$ & $1.14156 \mathrm{E}+10$ & $4.271 \mathrm{E}+09$ & $2.011 \mathrm{E}-01$ & $1.026 \mathrm{E}+10$ \\
\hline 1B2T2L4F & Transverse (WG) & 1813.0 & 2501.0 & $1.539 \mathrm{E}+03$ & $1.13400 \mathrm{E}+10$ & $4.293 \mathrm{E}+09$ & $1.954 \mathrm{E}-01$ & $1.026 \mathrm{E}+10$ \\
\hline 1B2T2L6F & Transverse (WG) & 1819.5 & 2505.2 & $1.534 \mathrm{E}+03$ & $1.14189 \mathrm{E}+10$ & $4.279 \mathrm{E}+09$ & $2.003 \mathrm{E}-01$ & $1.027 \mathrm{E}+10$ \\
\hline 1B2T3L2F & Transverse (WG) & 1820.1 & 2508.2 & $1.546 \mathrm{E}+03$ & $1.14507 \mathrm{E}+10$ & $4.351 \mathrm{E}+09$ & $1.936 \mathrm{E}-01$ & $1.039 \mathrm{E}+10$ \\
\hline 1B2T3L4F & Transverse (WG) & 1820.6 & 2503.9 & $1.522 \mathrm{E}+03$ & $1.14144 \mathrm{E}+10$ & $4.219 \mathrm{E}+09$ & $2.069 \mathrm{E}-01$ & $1.018 \mathrm{E}+10$ \\
\hline 1B2T3L6F & Transverse (WG) & 1816.0 & 2491.2 & $1.519 \mathrm{E}+03$ & $1.12701 \mathrm{E}+10$ & $4.190 \mathrm{E}+09$ & $2.041 \mathrm{E}-01$ & $1.009 \mathrm{E}+10$ \\
\hline 1B3P1P1F & Parallel (AG) & 1828.6 & 2447.7 & $1.530 \mathrm{E}+03$ & $1.09559 \mathrm{E}+10$ & $4.282 \mathrm{E}+09$ & $1.792 \mathrm{E}-01$ & $1.010 \mathrm{E}+10$ \\
\hline 1B3P1P3F & Parallel (AG) & 1830.2 & 2474.8 & $1.543 \mathrm{E}+03$ & $1.12097 \mathrm{E}+10$ & $4.356 \mathrm{E}+09$ & $1.823 \mathrm{E}-01$ & $1.030 \mathrm{E}+10$ \\
\hline 1B3P1P5F & Parallel (AG) & 1831.6 & 2493.3 & $1.543 \mathrm{E}+03$ & $1.13860 \mathrm{E}+10$ & $4.360 \mathrm{E}+09$ & $1.897 \mathrm{E}-01$ & $1.037 \mathrm{E}+10$ \\
\hline
\end{tabular}


Table A.13. Sonic velocity (TOF) derived elastic constants for graphite grade 2114 billet 116310 (continued)

\begin{tabular}{|c|c|c|c|c|c|c|c|c|}
\hline \multirow{3}{*}{$\begin{array}{l}\text { Specimen } \\
\text { number }\end{array}$} & \multirow[b]{3}{*}{ Grain orientation } & \multirow{3}{*}{$\begin{array}{l}\text { Density, } \rho \\
\left(\mathrm{Kg} / \mathbf{m}^{3}\right)\end{array}$} & \multirow{2}{*}{\multicolumn{2}{|c|}{ Sonic velocities, $\cup[\mathbf{m} / \mathbf{s}]$}} & \multicolumn{4}{|c|}{ ELASTIC CONSTANTS } \\
\hline & & & & & \multirow[b]{2}{*}{$\begin{array}{c}\text { Elastic } \\
\text { modulus, }[\mathrm{Pa}]\end{array}$} & \multirow[b]{2}{*}{$\begin{array}{c}\text { Shear } \\
\text { modulus, }[\mathrm{Pa}]\end{array}$} & \multirow[b]{2}{*}{ Poisson's ratio } & \multirow[b]{2}{*}{$\begin{array}{l}\text { Poisson's corrected } \\
\text { elastic modulus, }[\mathrm{Pa}]\end{array}$} \\
\hline & & & Longitudinal & $\begin{array}{l}\text { Average } \\
\text { shear } \\
\text { velocity }\end{array}$ & & & & \\
\hline 1B3P4P1F & Parallel (AG) & 1815.2 & 2444.6 & $1.504 \mathrm{E}+03$ & $1.08472 \mathrm{E}+10$ & $4.106 \mathrm{E}+09$ & $1.954 \mathrm{E}-01$ & $9.817 \mathrm{E}+09$ \\
\hline 1B3P4P3F & Parallel (AG) & 1818.9 & 2418.1 & $1.519 \mathrm{E}+03$ & $1.06352 \mathrm{E}+10$ & $4.194 \mathrm{E}+09$ & $1.744 \mathrm{E}-01$ & $9.852 \mathrm{E}+09$ \\
\hline 1B3P4P5F & Parallel (AG) & 1821.4 & 2453.6 & $1.521 \mathrm{E}+03$ & $1.09652 \mathrm{E}+10$ & $4.214 \mathrm{E}+09$ & $1.879 \mathrm{E}-01$ & $1.001 \mathrm{E}+10$ \\
\hline 1B3T2L2F & Transverse (WG) & 1826.5 & 2557.3 & $1.559 \mathrm{E}+03$ & $1.19454 \mathrm{E}+10$ & $4.438 \mathrm{E}+09$ & $2.045 \mathrm{E}-01$ & $1.069 \mathrm{E}+10$ \\
\hline 1B3T2L4F & Transverse (WG) & 1824.3 & 2536.9 & $1.559 \mathrm{E}+03$ & $1.17405 \mathrm{E}+10$ & $4.436 \mathrm{E}+09$ & $1.964 \mathrm{E}-01$ & $1.061 \mathrm{E}+10$ \\
\hline 1B3T2L6F & Transverse (WG) & 1820.2 & 2517.9 & $1.545 \mathrm{E}+03$ & $1.15400 \mathrm{E}+10$ & $4.347 \mathrm{E}+09$ & $1.978 \mathrm{E}-01$ & $1.041 \mathrm{E}+10$ \\
\hline \multirow{3}{*}{$\begin{array}{l}\text { 1B3T3L2F } \\
\text { 1B3T3L4F } \\
1 B 3 T 3 L 6 F\end{array}$} & Transverse (WG) & 1820.3 & 2519.9 & $1.542 \mathrm{E}+03$ & $1.15590 \mathrm{E}+10$ & $4.330 \mathrm{E}+09$ & $2.005 \mathrm{E}-01$ & $1.040 \mathrm{E}+10$ \\
\hline & Transverse (WG) & 1822.4 & 2540.4 & $1.562 \mathrm{E}+03$ & $1.17615 \mathrm{E}+10$ & $4.445 \mathrm{E}+09$ & $1.962 \mathrm{E}-01$ & $1.063 \mathrm{E}+10$ \\
\hline & Transverse (WG) & 1823.6 & 2544.8 & $1.547 \mathrm{E}+03$ & $1.18092 \mathrm{E}+10$ & $4.365 \mathrm{E}+09$ & $2.069 \mathrm{E}-01$ & $1.053 \mathrm{E}+10$ \\
\hline 5A1P1P1F & Parallel (AG) & 1816.6 & 2493.8 & $1.525 \mathrm{E}+03$ & $1.12970 \mathrm{E}+10$ & $4.226 \mathrm{E}+09$ & $2.011 \mathrm{E}-01$ & $1.015 \mathrm{E}+10$ \\
\hline 5A1P1P3F & Parallel (AG) & 1817.1 & 2503.1 & $1.532 \mathrm{E}+03$ & $1.13852 \mathrm{E}+10$ & $4.266 \mathrm{E}+09$ & $2.004 \mathrm{E}-01$ & $1.024 \mathrm{E}+10$ \\
\hline 5A1P1P5FR & Parallel (AG) & 1815.5 & 2515.3 & $1.534 \mathrm{E}+03$ & $1.14861 \mathrm{E}+10$ & $4.272 \mathrm{E}+09$ & $2.039 \mathrm{E}-01$ & $1.029 \mathrm{E}+10$ \\
\hline 5A1P4P1F & Parallel (AG) & 1816.0 & 2474.9 & $1.527 \mathrm{E}+03$ & $1.11235 \mathrm{E}+10$ & $4.236 \mathrm{E}+09$ & $1.925 \mathrm{E}-01$ & $1.010 \mathrm{E}+10$ \\
\hline 5A1P4P3F & Parallel (AG) & 1816.5 & 2476.5 & $1.528 \mathrm{E}+03$ & $1.11407 \mathrm{E}+10$ & $4.241 \mathrm{E}+09$ & $1.927 \mathrm{E}-01$ & $1.012 \mathrm{E}+10$ \\
\hline 5A1P4P5F & Parallel (AG) & 1814.7 & 2482.6 & $1.526 \mathrm{E}+03$ & $1.11845 \mathrm{E}+10$ & $4.229 \mathrm{E}+09$ & $1.960 \mathrm{E}-01$ & $1.012 \mathrm{E}+10$ \\
\hline 5A1T2L2F & Transverse (WG) & 1816.2 & 2548.7 & $1.541 \mathrm{E}+03$ & $1.17973 \mathrm{E}+10$ & $4.312 \mathrm{E}+09$ & $2.120 \mathrm{E}-01$ & $1.045 \mathrm{E}+10$ \\
\hline 5A1T2L4F & Transverse (WG) & 1815.2 & 2546.5 & $1.544 \mathrm{E}+03$ & $1.17703 \mathrm{E}+10$ & $4.326 \mathrm{E}+09$ & $2.095 \mathrm{E}-01$ & $1.046 \mathrm{E}+10$ \\
\hline 5A1T2L6F & Transverse (WG) & 1816.7 & 2538.0 & $1.536 \mathrm{E}+03$ & $1.17017 \mathrm{E}+10$ & $4.289 \mathrm{E}+09$ & $2.107 \mathrm{E}-01$ & $1.038 \mathrm{E}+10$ \\
\hline 5A1T3L2FR & Transverse (WG) & 1816.3 & 2533.9 & $1.537 \mathrm{E}+03$ & $1.16617 \mathrm{E}+10$ & $4.292 \mathrm{E}+09$ & $2.088 \mathrm{E}-01$ & $1.038 \mathrm{E}+10$ \\
\hline
\end{tabular}


Table A.13. Sonic velocity (TOF) derived elastic constants for graphite grade 2114 billet 116310 (continued)

\begin{tabular}{|c|c|c|c|c|c|c|c|c|}
\hline \multirow{3}{*}{$\begin{array}{l}\text { Specimen } \\
\text { number }\end{array}$} & \multirow[b]{3}{*}{ Grain orientation } & \multirow{3}{*}{$\begin{array}{l}\text { Density, } \rho \\
\left(\mathrm{Kg} / \mathbf{m}^{3}\right)\end{array}$} & \multirow{2}{*}{\multicolumn{2}{|c|}{ Sonic velocities, $u[\mathbf{m} / \mathbf{s}]$}} & \multicolumn{4}{|c|}{ ELASTIC CONSTANTS } \\
\hline & & & & & \multirow[b]{2}{*}{$\begin{array}{c}\text { Elastic } \\
\text { modulus, }[\mathrm{Pa}]\end{array}$} & \multirow[b]{2}{*}{$\begin{array}{c}\text { Shear } \\
\text { modulus, }[\mathrm{Pa}]\end{array}$} & \multirow[b]{2}{*}{ Poisson's ratio } & \multirow[b]{2}{*}{$\begin{array}{l}\text { Poisson's corrected } \\
\text { elastic modulus, }[\mathrm{Pa}]\end{array}$} \\
\hline & & & Longitudinal & $\begin{array}{l}\text { Average } \\
\text { shear } \\
\text { velocity }\end{array}$ & & & & \\
\hline 5A1T3L4F & Transverse (WG) & 1817.7 & 2536.8 & $1.528 \mathrm{E}+03$ & $1.16976 \mathrm{E}+10$ & $4.242 \mathrm{E}+09$ & $2.155 \mathrm{E}-01$ & $1.031 \mathrm{E}+10$ \\
\hline 5A1T3L6F & Transverse (WG) & 1819.0 & 2554.1 & $1.549 \mathrm{E}+03$ & $1.18655 \mathrm{E}+10$ & $4.366 \mathrm{E}+09$ & $2.089 \mathrm{E}-01$ & $1.056 \mathrm{E}+10$ \\
\hline 5B3P1P1F & Parallel (AG) & 1820.0 & 2524.4 & $1.528 \mathrm{E}+03$ & $1.15982 \mathrm{E}+10$ & $4.248 \mathrm{E}+09$ & $2.110 \mathrm{E}-01$ & $1.029 \mathrm{E}+10$ \\
\hline 5B3P1P3F & Parallel (AG) & 1820.0 & 2527.7 & $1.547 \mathrm{E}+03$ & $1.16285 \mathrm{E}+10$ & $4.354 \mathrm{E}+09$ & $2.007 \mathrm{E}-01$ & $1.046 \mathrm{E}+10$ \\
\hline 5B3P1P5F & Parallel (AG) & 1820.0 & 2521.5 & $1.543 \mathrm{E}+03$ & $1.15717 \mathrm{E}+10$ & $4.335 \mathrm{E}+09$ & $2.005 \mathrm{E}-01$ & $1.041 \mathrm{E}+10$ \\
\hline 5B3P4P1F & Parallel (AG) & 1822.9 & 2548.1 & $1.546 \mathrm{E}+03$ & $1.18355 \mathrm{E}+10$ & $4.355 \mathrm{E}+09$ & $2.089 \mathrm{E}-01$ & $1.053 \mathrm{E}+10$ \\
\hline 5B3P4P3F & Parallel (AG) & 1823.5 & 2543.2 & $1.551 \mathrm{E}+03$ & $1.17934 \mathrm{E}+10$ & $4.389 \mathrm{E}+09$ & $2.036 \mathrm{E}-01$ & $1.057 \mathrm{E}+10$ \\
\hline 5B3P4P5FR & Parallel (AG) & 1815.8 & 2538.4 & $1.549 \mathrm{E}+03$ & $1.17001 \mathrm{E}+10$ & $4.357 \mathrm{E}+09$ & $2.034 \mathrm{E}-01$ & $1.049 \mathrm{E}+10$ \\
\hline 5B3T2L2FR & Transverse (WG) & 1825.5 & 2515.9 & $1.537 \mathrm{E}+03$ & $1.15551 \mathrm{E}+10$ & $4.313 \mathrm{E}+09$ & $2.022 \mathrm{E}-01$ & $1.037 \mathrm{E}+10$ \\
\hline 5B3T2L4F & Transverse (WG) & 1820.2 & 2509.1 & $1.534 \mathrm{E}+03$ & $1.14591 \mathrm{E}+10$ & $4.284 \mathrm{E}+09$ & $2.015 \mathrm{E}-01$ & $1.029 \mathrm{E}+10$ \\
\hline 5B3T2L6F & Transverse (WG) & 1820.2 & 2510.9 & $1.535 \mathrm{E}+03$ & $1.14758 \mathrm{E}+10$ & $4.290 \mathrm{E}+09$ & $2.014 \mathrm{E}-01$ & $1.031 \mathrm{E}+10$ \\
\hline 5B3T3L2F & Transverse (WG) & 1819.2 & 2501.2 & $1.535 \mathrm{E}+03$ & $1.13813 \mathrm{E}+10$ & $4.288 \mathrm{E}+09$ & $1.977 \mathrm{E}-01$ & $1.027 \mathrm{E}+10$ \\
\hline 5B3T3L4F & Transverse (WG) & 1820.7 & 2502.7 & $1.527 \mathrm{E}+03$ & $1.14042 \mathrm{E}+10$ & $4.246 \mathrm{E}+09$ & $2.034 \mathrm{E}-01$ & $1.022 \mathrm{E}+10$ \\
\hline 5B3T3L6F & Transverse (WG) & 1824.9 & 2498.7 & $1.532 \mathrm{E}+03$ & $1.13935 \mathrm{E}+10$ & $4.285 \mathrm{E}+09$ & $1.986 \mathrm{E}-01$ & $1.027 \mathrm{E}+10$ \\
\hline
\end{tabular}


Table A.14. Sonic velocity (TOF) derived elastic constants for graphite grade 2114 billet 116310 in the AG orientation

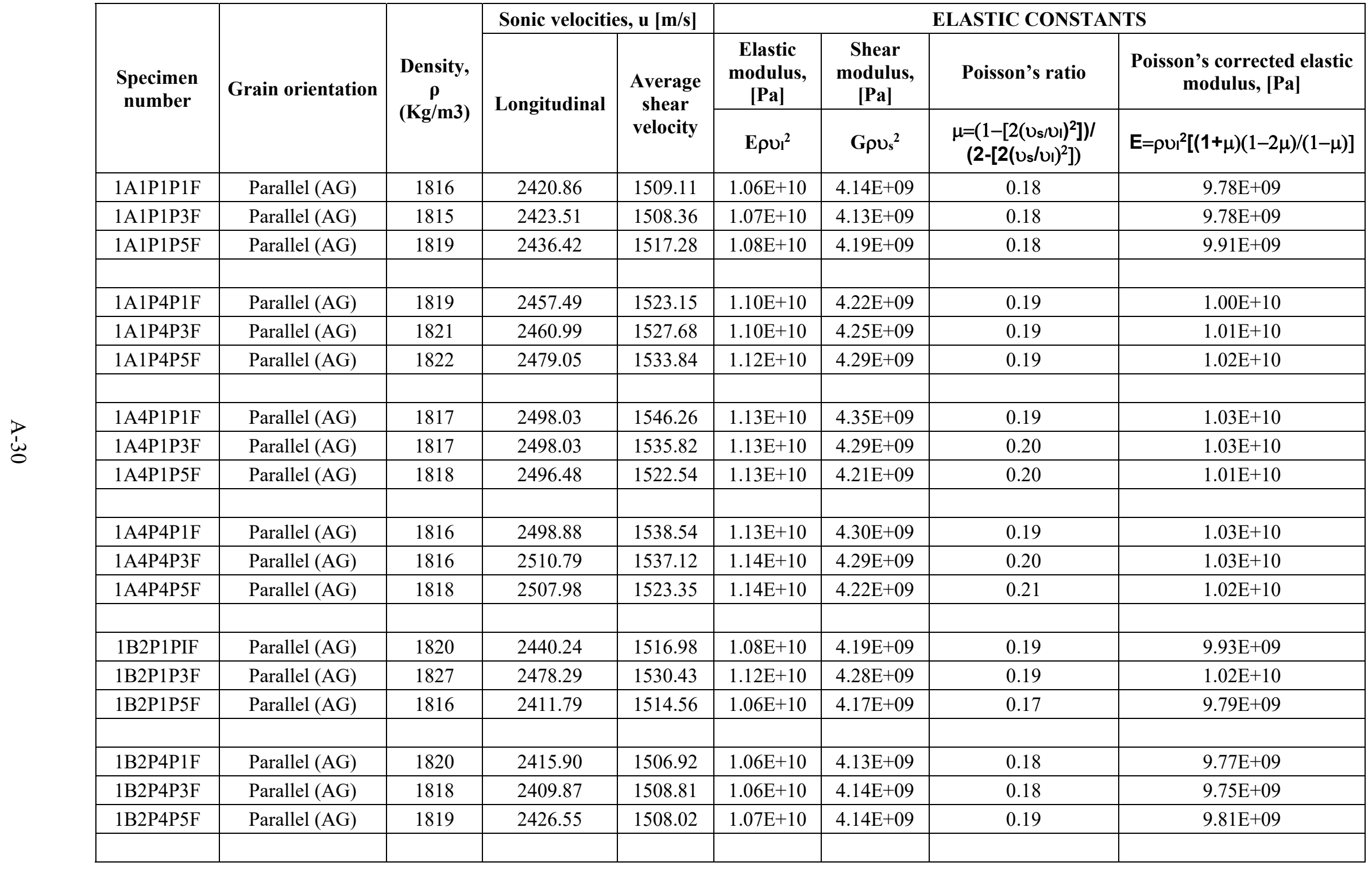


Table A.14. Sonic velocity (TOF) derived elastic constants for graphite grade 2114 billet 116310 in the AG orientation (continued)

\begin{tabular}{|c|c|c|c|c|c|c|c|c|}
\hline \multirow{3}{*}{$\begin{array}{l}\text { Specimen } \\
\text { number }\end{array}$} & \multirow{3}{*}{ Grain orientation } & \multirow{3}{*}{$\begin{array}{c}\text { Density, } \\
\rho \\
(\mathrm{Kg} / \mathrm{m} 3)\end{array}$} & \multicolumn{2}{|c|}{ Sonic velocities, $u[\mathrm{~m} / \mathrm{s}]$} & \multicolumn{4}{|c|}{ ELASTIC CONSTANTS } \\
\hline & & & \multirow{2}{*}{ Longitudinal } & \multirow{2}{*}{$\begin{array}{l}\text { Average } \\
\text { shear } \\
\text { velocity }\end{array}$} & $\begin{array}{c}\begin{array}{c}\text { Elastic } \\
\text { modulus, } \\
{[\mathrm{Pa}]}\end{array} \\
\end{array}$ & $\begin{array}{c}\begin{array}{c}\text { Shear } \\
\text { modulus, } \\
{[\mathrm{Pa}]}\end{array} \\
\end{array}$ & Poisson's ratio & $\begin{array}{c}\text { Poisson's corrected elastic } \\
\text { modulus, }[\mathrm{Pa}]\end{array}$ \\
\hline & & & & & E $\rho v_{1}^{2}$ & Govs ${ }^{2}$ & $\begin{array}{c}\mu=\left(1-\left[2\left(U_{s} / U_{I}\right)^{2}\right]\right) / \\
\left(2-\left[2\left(U_{s} / U_{I}\right)^{2}\right]\right)\end{array}$ & $E=\rho v^{2}[(1+\mu)(1-2 \mu) /(1-\mu)]$ \\
\hline 1B3P1P1F & Parallel (AG) & 1829 & 2447.70 & 1530.23 & $1.10 \mathrm{E}+10$ & $4.28 \mathrm{E}+09$ & 0.18 & $1.01 \mathrm{E}+10$ \\
\hline 1B3P1P3F & Parallel (AG) & 1830 & 2474.82 & 1542.68 & $1.12 \mathrm{E}+10$ & $4.36 \mathrm{E}+09$ & 0.18 & $1.03 \mathrm{E}+10$ \\
\hline 1B3P1P5F & Parallel (AG) & 1832 & 2493.29 & 1542.84 & $1.14 \mathrm{E}+10$ & $4.36 \mathrm{E}+09$ & 0.19 & $1.04 \mathrm{E}+10$ \\
\hline 1B3P4P1F & Parallel (AG) & 1815 & 2444.56 & 1504.05 & $1.08 \mathrm{E}+10$ & $4.11 \mathrm{E}+09$ & 0.20 & $9.82 \mathrm{E}+09$ \\
\hline 1B3P4P3F & Parallel (AG) & 1819 & 2418.10 & 1518.54 & $1.06 \mathrm{E}+10$ & $4.19 \mathrm{E}+09$ & 0.17 & $9.85 \mathrm{E}+09$ \\
\hline 1B3P4P5F & Parallel (AG) & 1821 & 2453.62 & 1521.01 & $1.10 \mathrm{E}+10$ & $4.21 \mathrm{E}+09$ & 0.19 & $1.00 \mathrm{E}+10$ \\
\hline 5A1P1P1F & Parallel (AG) & 1817 & 2493.78 & 1525.33 & $1.13 \mathrm{E}+10$ & $4.23 \mathrm{E}+09$ & 0.20 & $1.02 \mathrm{E}+10$ \\
\hline 5A1P1P3F & Parallel (AG) & 1817 & 2503.12 & 1532.17 & $1.14 \mathrm{E}+10$ & $4.27 \mathrm{E}+09$ & 0.20 & $1.02 \mathrm{E}+10$ \\
\hline 5A1P1P5FR & Parallel (AG) & 1815 & 2515.29 & 1534.02 & $1.15 \mathrm{E}+10$ & $4.27 \mathrm{E}+09$ & 0.20 & $1.03 \mathrm{E}+10$ \\
\hline 5A1P4P1F & Parallel (AG) & 1816 & 2474.91 & 1527.26 & $1.11 \mathrm{E}+10$ & $4.24 \mathrm{E}+09$ & 0.19 & $1.01 \mathrm{E}+10$ \\
\hline 5A1P4P3F & Parallel (AG) & 1816 & 2476.51 & 1527.98 & $1.11 \mathrm{E}+10$ & $4.24 \mathrm{E}+09$ & 0.19 & $1.01 \mathrm{E}+10$ \\
\hline 5A1P4P5F & Parallel (AG) & 1815 & 2482.57 & 1526.50 & $1.12 \mathrm{E}+10$ & $4.23 \mathrm{E}+09$ & 0.20 & $1.01 \mathrm{E}+10$ \\
\hline 5B3P1P1F & Parallel (AG) & 1820 & 2524.44 & 1527.77 & $1.16 \mathrm{E}+10$ & $4.25 \mathrm{E}+09$ & 0.21 & $1.03 \mathrm{E}+10$ \\
\hline 5B3P1P3F & Parallel (AG) & 1820 & 2527.69 & 1546.78 & $1.16 \mathrm{E}+10$ & $4.35 \mathrm{E}+09$ & 0.20 & $1.05 \mathrm{E}+10$ \\
\hline 5B3P1P5F & Parallel (AG) & 1820 & 2521.52 & 1543.25 & $1.16 \mathrm{E}+10$ & $4.33 \mathrm{E}+09$ & 0.20 & $1.04 \mathrm{E}+10$ \\
\hline 5B3P4P1F & Parallel (AG) & 1823 & 2548.08 & 1545.70 & $1.18 \mathrm{E}+10$ & $4.36 \mathrm{E}+09$ & 0.21 & $1.05 \mathrm{E}+10$ \\
\hline 5B3P4P3F & Parallel (AG) & 1823 & 2543.16 & 1551.43 & $1.18 \mathrm{E}+10$ & $4.39 \mathrm{E}+09$ & 0.20 & $1.06 \mathrm{E}+10$ \\
\hline 5B3P4P5FR & Parallel (AG) & 1816 & 2538.40 & 1548.95 & $1.17 \mathrm{E}+10$ & $4.36 \mathrm{E}+09$ & 0.20 & $1.05 \mathrm{E}+10$ \\
\hline
\end{tabular}


Table A.15. Sonic velocity (TOF) derived elastic constants for graphite grade 2114 billet 116310 in the WG orientation

\begin{tabular}{|c|c|c|c|c|c|c|c|c|}
\hline \multirow{3}{*}{$\begin{array}{l}\text { Specimen } \\
\text { number }\end{array}$} & \multirow{3}{*}{ Grain orientation } & \multirow{3}{*}{$\begin{array}{c}\text { Density, } \\
\rho \\
(\mathrm{Kg} / \mathrm{m3})\end{array}$} & \multicolumn{2}{|c|}{ Sonic velocities, $\mathbf{u}[\mathrm{m} / \mathrm{s}]$} & \multicolumn{4}{|c|}{ ELASTIC CONSTANTS } \\
\hline & & & \multirow{2}{*}{ Longitudinal } & \multirow{2}{*}{$\begin{array}{l}\text { Average } \\
\text { shear } \\
\text { velocity }\end{array}$} & $\begin{array}{c}\text { Elastic } \\
\text { modulus, } \\
{[\mathrm{Pa}]}\end{array}$ & $\begin{array}{c}\begin{array}{c}\text { Shear } \\
\text { modulus, } \\
{[\mathrm{Pa}]}\end{array} \\
\end{array}$ & Poisson's ratio & $\begin{array}{c}\text { Poisson's corrected elastic } \\
\text { modulus, }[\mathrm{Pa}]\end{array}$ \\
\hline & & & & & E $\rho v 1^{2}$ & ${\text { G } \rho v_{s}^{2}}^{2}$ & $\begin{array}{c}\mu=\left(1-\left[2\left(U_{s} / U_{I}\right)^{2}\right]\right) /(2- \\
\left.\left[2\left(U_{s} / U_{I}\right)^{2}\right]\right)\end{array}$ & $E=\rho v^{2}[(1+\mu)(1-2 \mu) /(1-\mu)]$ \\
\hline 1A1T2L2F & Transverse (WG) & 1815 & 2440.52 & 1525.57 & $1.08 \mathrm{E}+10$ & $4.22 \mathrm{E}+09$ & 0.18 & $9.96 \mathrm{E}+09$ \\
\hline 1A1T2L4F & Transverse (WG) & 1816 & 2503.78 & 1521.52 & $1.14 \mathrm{E}+10$ & $4.20 \mathrm{E}+09$ & 0.21 & $1.01 \mathrm{E}+10$ \\
\hline 1A1T2L6F & Transverse (WG) & 1817 & 2489.71 & 1535.25 & $1.13 \mathrm{E}+10$ & $4.28 \mathrm{E}+09$ & 0.19 & $1.02 \mathrm{E}+10$ \\
\hline 1AIT3L2F & Transverse (WG) & 1816 & 2528.70 & 1539.08 & $1.16 \mathrm{E}+10$ & $4.30 \mathrm{E}+09$ & 0.21 & $1.04 \mathrm{E}+10$ \\
\hline 1AIT3L4F & Transverse (WG) & 1818 & 2538.47 & 1529.76 & $1.17 \mathrm{E}+10$ & $4.25 \mathrm{E}+09$ & 0.21 & $1.03 \mathrm{E}+10$ \\
\hline 1AIT3L6F & Transverse (WG) & 1820 & 2528.87 & 1526.50 & $1.16 \mathrm{E}+10$ & $4.24 \mathrm{E}+09$ & 0.21 & $1.03 \mathrm{E}+10$ \\
\hline & & & & & & & & \\
\hline 1A4T3L2F & Transverse (WG) & 1818 & 2429.21 & 1506.43 & $1.07 \mathrm{E}+10$ & $4.12 \mathrm{E}+09$ & 0.19 & $9.80 \mathrm{E}+09$ \\
\hline 1A4T3L4F & Transverse (WG) & 1816 & 2423.72 & 1507.72 & $1.07 \mathrm{E}+10$ & $4.13 \mathrm{E}+09$ & 0.18 & $9.78 \mathrm{E}+09$ \\
\hline 1A4T3L6F & Transverse (WG) & 1823 & 2476.28 & 1526.04 & $1.12 \mathrm{E}+10$ & $4.24 \mathrm{E}+09$ & 0.19 & $1.01 \mathrm{E}+10$ \\
\hline 1A4T2L2F & Transverse (WG) & 1819 & 2429.80 & 1510.71 & $1.07 \mathrm{E}+10$ & $4.15 \mathrm{E}+09$ & 0.18 & $9.84 \mathrm{E}+09$ \\
\hline 1A4T2L4F & Transverse (WG) & 1817 & 2412.92 & 1503.65 & $1.06 \mathrm{E}+10$ & $4.11 \mathrm{E}+09$ & 0.18 & $9.72 \mathrm{E}+09$ \\
\hline 1A4T2L6F & Transverse (WG) & 1816 & 2403.96 & 1498.52 & $1.05 \mathrm{E}+10$ & $4.08 \mathrm{E}+09$ & 0.18 & $9.64 \mathrm{E}+09$ \\
\hline 1B2T2L2F & Transverse (WG) & 1818 & 2505.67 & 1532.58 & $1.14 \mathrm{E}+10$ & $4.27 \mathrm{E}+09$ & 0.20 & $1.03 \mathrm{E}+10$ \\
\hline 1B2T2L4F & Transverse (WG) & 1813 & 2500.98 & 1538.83 & $1.13 \mathrm{E}+10$ & $4.29 \mathrm{E}+09$ & 0.20 & $1.03 \mathrm{E}+10$ \\
\hline 1B2T2L6F & Transverse (WG) & 1819 & 2505.18 & 1533.62 & $1.14 \mathrm{E}+10$ & $4.28 \mathrm{E}+09$ & 0.20 & $1.03 \mathrm{E}+10$ \\
\hline 1B2T3L2F & Transverse (WG) & 1820 & 2508.23 & 1546.07 & $1.15 \mathrm{E}+10$ & $4.35 \mathrm{E}+09$ & 0.19 & $1.04 \mathrm{E}+10$ \\
\hline 1B2T3L4F & Transverse (WG) & 1821 & 2503.94 & 1522.23 & $1.14 \mathrm{E}+10$ & $4.22 \mathrm{E}+09$ & 0.21 & $1.02 \mathrm{E}+10$ \\
\hline 1B2T3L6F & Transverse (WG) & 1816 & 2491.17 & 1518.90 & $1.13 \mathrm{E}+10$ & $4.19 \mathrm{E}+09$ & 0.20 & $1.01 \mathrm{E}+10$ \\
\hline & & & & & & & & \\
\hline
\end{tabular}


Table A.15. Sonic velocity (TOF) derived elastic constants for graphite grade 2114 billet 116310 in the WG orientation (continued)

\begin{tabular}{|c|c|c|c|c|c|c|c|c|}
\hline \multirow{3}{*}{$\begin{array}{l}\text { Specimen } \\
\text { number }\end{array}$} & \multirow{3}{*}{ Grain orientation } & \multirow{3}{*}{$\begin{array}{c}\text { Density, } \\
\rho \\
(\mathrm{Kg} / \mathrm{m} 3)\end{array}$} & \multicolumn{2}{|c|}{ Sonic velocities, $\mathbf{u}[\mathrm{m} / \mathrm{s}]$} & \multicolumn{4}{|c|}{ ELASTIC CONSTANTS } \\
\hline & & & \multirow{2}{*}{ Longitudinal } & \multirow{2}{*}{$\begin{array}{l}\text { Average } \\
\text { shear } \\
\text { velocity }\end{array}$} & $\begin{array}{c}\text { Elastic } \\
\text { modulus, } \\
{[\mathrm{Pa}]}\end{array}$ & $\begin{array}{c}\text { Shear } \\
\text { modulus, } \\
{[\mathrm{Pa}]}\end{array}$ & Poisson's ratio & $\begin{array}{c}\text { Poisson's corrected elastic } \\
\text { modulus, }[\mathrm{Pa}]\end{array}$ \\
\hline & & & & & E $\rho v^{2}{ }^{2}$ & Gevis ${ }^{2}$ & $\begin{array}{c}\mu=\left(1-\left[2\left(U_{s} / U_{I}\right)^{2}\right]\right) /(2- \\
\left.\left[2\left(U_{s} / U_{I}\right)^{2}\right]\right)\end{array}$ & $E=\rho v^{2}[(1+\mu)(1-2 \mu) /(1-\mu)]$ \\
\hline 1B3T2L2F & Transverse (WG) & 1827 & 2557.34 & 1558.69 & $1.19 \mathrm{E}+10$ & $4.44 \mathrm{E}+09$ & 0.20 & $1.07 \mathrm{E}+10$ \\
\hline 1B3T2L4F & Transverse (WG) & 1824 & 2536.87 & 1559.29 & $1.17 \mathrm{E}+10$ & $4.44 \mathrm{E}+09$ & 0.20 & $1.06 \mathrm{E}+10$ \\
\hline 1B3T2L6F & Transverse (WG) & 1820 & 2517.93 & 1545.43 & $1.15 \mathrm{E}+10$ & $4.35 \mathrm{E}+09$ & 0.20 & $1.04 \mathrm{E}+10$ \\
\hline 1B3T3L2F & Transverse (WG) & 1820 & 2519.93 & 1542.26 & $1.16 \mathrm{E}+10$ & $4.33 \mathrm{E}+09$ & 0.20 & $1.04 \mathrm{E}+10$ \\
\hline 1B3T3L4F & Transverse (WG) & 1822 & 2540.42 & 1561.73 & $1.18 \mathrm{E}+10$ & $4.44 \mathrm{E}+09$ & 0.20 & $1.06 \mathrm{E}+10$ \\
\hline 1B3T3L6F & Transverse (WG) & 1824 & 2544.76 & 1547.06 & $1.18 \mathrm{E}+10$ & $4.36 \mathrm{E}+09$ & 0.21 & $1.05 \mathrm{E}+10$ \\
\hline 5A1T2L2F & Transverse (WG) & 1816 & 2548.68 & 1540.86 & $1.18 \mathrm{E}+10$ & $4.31 \mathrm{E}+09$ & 0.21 & $1.05 \mathrm{E}+10$ \\
\hline 5A1T2L4F & Transverse (WG) & 1815 & 2546.46 & 1543.71 & $1.18 \mathrm{E}+10$ & $4.33 \mathrm{E}+09$ & 0.21 & $1.05 \mathrm{E}+10$ \\
\hline 5A1T2L6F & Transverse (WG) & 1817 & 2537.97 & 1536.45 & $1.17 \mathrm{E}+10$ & $4.29 \mathrm{E}+09$ & 0.21 & $1.04 \mathrm{E}+10$ \\
\hline 5A1T3L2FR & Transverse (WG) & 1816 & 2533.92 & 1537.33 & $1.17 \mathrm{E}+10$ & $4.29 \mathrm{E}+09$ & 0.21 & $1.04 \mathrm{E}+10$ \\
\hline 5A1T3L4F & Transverse (WG) & 1818 & 2536.80 & 1527.72 & $1.17 \mathrm{E}+10$ & $4.24 \mathrm{E}+09$ & 0.22 & $1.03 \mathrm{E}+10$ \\
\hline 5A1T3L6F & Transverse (WG) & 1819 & 2554.06 & 1549.31 & $1.19 \mathrm{E}+10$ & $4.37 \mathrm{E}+09$ & 0.21 & $1.06 \mathrm{E}+10$ \\
\hline 5B3T2L2FR & Transverse (WG) & 1825 & 2515.93 & 1537.18 & $1.16 \mathrm{E}+10$ & $4.31 \mathrm{E}+09$ & 0.20 & $1.04 \mathrm{E}+10$ \\
\hline 5B3T2L4F & Transverse (WG) & 1820 & 2509.05 & 1534.13 & $1.15 \mathrm{E}+10$ & $4.28 \mathrm{E}+09$ & 0.20 & $1.03 \mathrm{E}+10$ \\
\hline 5B3T2L6F & Transverse (WG) & 1820 & 2510.88 & 1535.27 & $1.15 \mathrm{E}+10$ & $4.29 \mathrm{E}+09$ & 0.20 & $1.03 \mathrm{E}+10$ \\
\hline & & & & & & & & \\
\hline 5B3T3L2F & Transverse (WG) & 1819 & 2501.23 & 1535.26 & $1.14 \mathrm{E}+10$ & $4.29 \mathrm{E}+09$ & 0.20 & $1.03 \mathrm{E}+10$ \\
\hline 5B3T3L4F & Transverse (WG) & 1821 & 2502.71 & 1527.16 & $1.14 \mathrm{E}+10$ & $4.25 \mathrm{E}+09$ & 0.20 & $1.02 \mathrm{E}+10$ \\
\hline 5B3T3L6F & Transverse (WG) & 1825 & 2498.69 & 1532.32 & $1.14 \mathrm{E}+10$ & $4.28 \mathrm{E}+09$ & 0.20 & $1.03 \mathrm{E}+10$ \\
\hline
\end{tabular}


Table A.16. Sonic velocity (TOF) derived elastic constants for graphite grade 2114 billet 116310 in the AG orientation sorted by in-billet location

\begin{tabular}{|c|c|c|c|c|c|c|c|c|c|c|}
\hline \multirow{3}{*}{$\begin{array}{c}\text { Specimen } \\
\text { number }\end{array}$} & \multirow{3}{*}{$\begin{array}{c}\text { Grain } \\
\text { orientation }\end{array}$} & \multicolumn{3}{|c|}{ ELASTIC CONSTANTS } & \multirow{3}{*}{$\begin{array}{c}\text { Specimen } \\
\text { number }\end{array}$} & \multirow{3}{*}{$\begin{array}{c}\text { Grain } \\
\text { orientation }\end{array}$} & \multicolumn{4}{|c|}{ ELASTIC CONSTANTS } \\
\hline & & $\begin{array}{c}\text { Shear } \\
\text { modulus, } \\
{[\mathrm{Pa}]}\end{array}$ & $\begin{array}{l}\text { Poisson's } \\
\text { ratio }\end{array}$ & $\begin{array}{c}\text { Poisson's } \\
\text { corrected elastic } \\
\text { modulus, [Pa] }\end{array}$ & & & $\begin{array}{c}\text { Elastic } \\
\text { modulus, } \\
{\left[\begin{array}{l}\text { [Pa] }\end{array}\right.}\end{array}$ & $\begin{array}{c}\text { Shear } \\
\text { modulus, } \\
{[\mathrm{Pa}]}\end{array}$ & $\begin{array}{l}\text { Poisson's } \\
\text { ratio }\end{array}$ & $\begin{array}{c}\text { Poisson's } \\
\text { corrected } \\
\text { elastic } \\
\text { modulus, } \\
{[\mathrm{Pa}]} \\
\end{array}$ \\
\hline & & $G=\rho u s 2$ & $\begin{array}{c}\mu=(1- \\
{[2(\text { us/vl)2]) }} \\
/(2- \\
{[2(\text { us/vl)2]) }}\end{array}$ & $\begin{array}{c}E=\rho v 12[(1+\mu) \\
(1-2 \mu) /(1-\mu)]\end{array}$ & & & $E=\rho u l 2$ & $G=\rho u s 2$ & $\begin{array}{c}\mu=(1- \\
{[2(\text { us/vl)2]) }} \\
/(2- \\
{[2(\text { (us/vl)2]) }}\end{array}$ & $\begin{array}{c}E=\rho v l 2[(1+ \\
\mu)(1-2 \mu) /(1- \\
\mu)]\end{array}$ \\
\hline 1A1P1P1F & Parallel (AG) & $4.14 \mathrm{E}+09$ & \begin{tabular}{|l|}
0.18 \\
\end{tabular} & 9780508443 & 5A1P1P1F & Parallel (AG) & $1.13 \mathrm{E}+10$ & $4.23 \mathrm{E}+09$ & 0.20 & $1.015 \mathrm{E}+10$ \\
\hline 1A1P1P3F & Parallel (AG) & $4.13 \mathrm{E}+09$ & 0.18 & 9777304153 & 5A1P1P3F & Parallel (AG) & $1.14 \mathrm{E}+10$ & $4.27 \mathrm{E}+09$ & 0.20 & $1.024 \mathrm{E}+10$ \\
\hline 1A1P1P5F & Parallel (AG) & $4.19 \mathrm{E}+09$ & 0.18 & 9909427222 & 5A1P1P5FR & Parallel (AG) & $1.15 \mathrm{E}+10$ & $4.27 \mathrm{E}+09$ & 0.20 & $1.029 \mathrm{E}+10$ \\
\hline 1A1P4P1F & Parallel (AG) & $4.22 \mathrm{E}+09$ & 0.19 & 10030061290 & 5A1P4P1F & Parallel (AG) & $1.11 \mathrm{E}+10$ & $4.24 \mathrm{E}+09$ & 0.19 & $1.01 \mathrm{E}+10$ \\
\hline 1A1P4P3F & Parallel (AG) & $4.25 \mathrm{E}+09$ & 0.19 & 10083267503 & 5A1P4P3F & Parallel (AG) & $1.11 \mathrm{E}+10$ & $4.24 \mathrm{E}+09$ & 0.19 & $1.012 \mathrm{E}+10$ \\
\hline 1A1P4P5F & Parallel (AG) & $4.29 \mathrm{E}+09$ & 0.19 & 10203330013 & 5A1P4P5F & Parallel (AG) & $1.12 \mathrm{E}+10$ & $4.23 \mathrm{E}+09$ & 0.20 & $1.012 \mathrm{E}+10$ \\
\hline 1A4P1P1F & Parallel (AG) & $4.35 \mathrm{E}+09$ & 0.19 & 10336393806 & 5B3P1P1F & Parallel (AG) & $1.16 \mathrm{E}+10$ & $4.25 \mathrm{E}+09$ & 0.21 & $1.029 \mathrm{E}+10$ \\
\hline 1A4P1P3F & Parallel (AG) & $4.29 \mathrm{E}+09$ & 0.20 & 10254728279 & 5B3P1P3F & Parallel (AG) & $1.16 \mathrm{E}+10$ & $4.35 \mathrm{E}+09$ & 0.20 & $1.046 \mathrm{E}+10$ \\
\hline 1A4P1P5F & Parallel (AG) & $4.21 \mathrm{E}+09$ & 0.20 & 10147159704 & 5B3P1P5F & Parallel (AG) & $1.16 \mathrm{E}+10$ & $4.33 \mathrm{E}+09$ & 0.20 & $1.041 \mathrm{E}+10$ \\
\hline 1A4P4P1F & Parallel (AG) & $4.3 \mathrm{E}+09$ & 0.19 & 10273131918 & 5B3P4P1F & Parallel (AG) & $1.18 \mathrm{E}+10$ & $4.36 \mathrm{E}+09$ & 0.21 & $1.053 \mathrm{E}+10$ \\
\hline 1A4P4P3F & Parallel (AG) & $4.29 \mathrm{E}+09$ & 0.20 & 10299436809 & 5B3P4P3F & Parallel (AG) & $1.18 \mathrm{E}+10$ & $4.39 \mathrm{E}+09$ & 0.20 & $1.057 \mathrm{E}+10$ \\
\hline 1A4P4P5F & Parallel (AG) & $4.22 \mathrm{E}+09$ & 0.21 & 10191997598 & 5B3P4P5FR & Parallel (AG) & $1.17 \mathrm{E}+10$ & $4.36 \mathrm{E}+09$ & 0.20 & $1.049 \mathrm{E}+10$ \\
\hline 1B2P1PIF & Parallel (AG) & $4.19 \mathrm{E}+09$ & 0.19 & 9925158989 & & & & & & \\
\hline 1B2P1P3F & Parallel (AG) & $4.28 \mathrm{E}+09$ & 0.19 & 10200234462 & & & & & & \\
\hline 1B2P1P5F & Parallel (AG) & $4.17 \mathrm{E}+09$ & 0.17 & 9786843983 & & & & & & \\
\hline 1B2P4P1F & Parallel (AG) & $4.13 E+09$ & 0.18 & 9767363696 & & & & & & \\
\hline
\end{tabular}


Table A.16. Sonic velocity (TOF) derived elastic constants for graphite grade 2114 billet 116310 in the AG orientation sorted by in-billet location (continued)

\begin{tabular}{|c|c|c|c|c|c|c|c|c|c|c|}
\hline \multirow{3}{*}{$\begin{array}{c}\text { Specimen } \\
\text { number }\end{array}$} & \multirow{3}{*}{$\begin{array}{c}\text { Grain } \\
\text { orientation }\end{array}$} & \multicolumn{3}{|c|}{ ELASTIC CONSTANTS } & \multirow{3}{*}{$\begin{array}{c}\text { Specimen } \\
\text { number }\end{array}$} & \multirow{3}{*}{$\begin{array}{c}\text { Grain } \\
\text { orientation }\end{array}$} & \multicolumn{4}{|c|}{ ELASTIC CONSTANTS } \\
\hline & & \multirow{2}{*}{$\begin{array}{c}\begin{array}{c}\text { Shear } \\
\text { modulus, } \\
{[\mathrm{Pa}]}\end{array} \\
\mathbf{G}=\rho u s 2\end{array}$} & \multirow{2}{*}{\begin{tabular}{|c}
$\begin{array}{c}\text { Poisson's } \\
\text { ratio }\end{array}$ \\
$\begin{array}{c}\mu=(1- \\
[2(u s / v l) 2]) \\
/(2- \\
[2(u s / v l) 2])\end{array}$
\end{tabular}} & \multirow{2}{*}{\begin{tabular}{|c|}
$\begin{array}{c}\text { Poisson's } \\
\text { corrected elastic } \\
\text { modulus, [Pa] }\end{array}$ \\
\\
$\begin{array}{c}\mathrm{E}=\rho \mathrm{l} 2[(1+\mu) \\
(1-2 \mu) /(1-\mu)]\end{array}$
\end{tabular}} & & & \multirow{2}{*}{$\begin{array}{c}\begin{array}{c}\text { Elastic } \\
\text { modulus, } \\
{[\mathrm{Pa}]}\end{array} \\
\mathrm{E}=\rho \mathrm{ol} 2\end{array}$} & \multirow{2}{*}{$\begin{array}{c}\begin{array}{c}\text { Shear } \\
\text { modulus, } \\
{[\text { Pa] }}\end{array} \\
\text { G= ous2 }\end{array}$} & \multirow{2}{*}{\begin{tabular}{|c|}
$\begin{array}{c}\text { Poisson's } \\
\text { ratio }\end{array}$ \\
$\begin{array}{c}\mu=(1- \\
[2(u s / v l) 2]) \\
/(2- \\
[2(u s / v l) 2])\end{array}$ \\
\end{tabular}} & \multirow{2}{*}{ 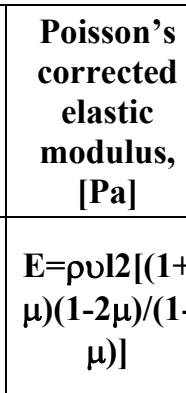 } \\
\hline & & & & & & & & & & \\
\hline 1B2P4P3F & Parallel (AG) & $4.14 \mathrm{E}+09$ & 0.18 & 9746646049 & & & & & & \\
\hline 1B2P4P5F & Parallel (AG) & $4.14 \mathrm{E}+09$ & 0.19 & 9809171638 & & & & & & \\
\hline & & & & & & & & & & \\
\hline 1B3P1P1F & Parallel (AG) & $4.28 \mathrm{E}+09$ & 0.18 & 10098642188 & & & & & & \\
\hline 1B3P1P3F & Parallel (AG) & $4.36 \mathrm{E}+09$ & 0.18 & 10299054603 & & & & & & \\
\hline 1B3P1P5F & Parallel (AG) & $4.36 \mathrm{E}+09$ & 0.19 & 10374102266 & & & & & & \\
\hline & & & & & & & & & & \\
\hline 1B3P4P1F & Parallel (AG) & $4.11 \mathrm{E}+09$ & 0.20 & 9817302926 & & & & & & \\
\hline 1B3P4P3F & Parallel (AG) & $4.19 \mathrm{E}+09$ & 0.17 & 9851500129 & & & & & & \\
\hline 1B3P4P5F & Parallel (AG) & $4.21 \mathrm{E}+09$ & 0.19 & 10011299253 & & & & & & \\
\hline
\end{tabular}


Table A.17. Sonic velocity (TOF) derived elastic constants for graphite grade 2114 billet 116310 in the WG orientation sorted by in-billet location

\begin{tabular}{|c|c|c|c|c|c|c|c|c|c|}
\hline \multirow{3}{*}{$\begin{array}{l}\text { Specimen } \\
\text { number }\end{array}$} & \multirow{3}{*}{$\begin{array}{c}\text { Grain } \\
\text { orientation }\end{array}$} & \multicolumn{3}{|c|}{ ELASTIC CONSTANTS } & \multirow{3}{*}{$\begin{array}{l}\text { Specimen } \\
\text { number }\end{array}$} & \multirow{3}{*}{$\begin{array}{c}\text { Grain } \\
\text { orientation }\end{array}$} & \multicolumn{3}{|c|}{ ELASTIC CONSTANTS } \\
\hline & & $\begin{array}{c}\text { Shear } \\
\text { modulus, } \\
{[\text { Pa] }}\end{array}$ & $\begin{array}{l}\text { Poisson's } \\
\text { ratio }\end{array}$ & $\begin{array}{c}\text { Poisson's } \\
\text { corrected } \\
\text { elastic } \\
\text { modulus, } \\
\text { [Pa] }\end{array}$ & & & $\begin{array}{c}\text { Shear } \\
\text { modulus, } \\
{[\mathrm{Pa}]}\end{array}$ & $\begin{array}{l}\text { Poisson's } \\
\text { ratio }\end{array}$ & $\begin{array}{c}\text { Poisson's } \\
\text { corrected } \\
\text { elastic } \\
\text { modulus, }[\mathrm{Pa}]\end{array}$ \\
\hline & & G $\rho u_{s}^{2}$ & $\begin{array}{c}\mu=\left(1-\left[2\left(v_{s} /\right.\right.\right. \\
\left.\left.\left.v_{I}\right)^{2}\right]\right) /(2- \\
\left.\left[2\left(v_{s} / v_{I}\right)^{2}\right]\right)\end{array}$ & $\begin{array}{c}E=\rho v^{2}[(1+\mu \\
)(1-2 \mu) /(1- \\
\mu)]\end{array}$ & & & $\mathbf{G}=\rho v^{2}{ }^{2}$ & $\begin{array}{c}\mu=\left(1-\left[2\left(U_{s} /\right.\right.\right. \\
\left.\left.\left.v_{I}\right)^{2}\right]\right) /(2- \\
\left.\left[2\left(U_{s} / v_{I}\right)^{2}\right]\right)\end{array}$ & $\begin{array}{c}E=\rho v^{2}[(1+\mu)(1 \\
-2 \mu) /(1-\mu)]\end{array}$ \\
\hline 1A1T2L2F & Transverse (WG) & $4.22 \mathrm{E}+09$ & 0.18 & $9.96 \mathrm{E}+09$ & 5A1T2L2F & Transverse (WG) & $4.31 \mathrm{E}+09$ & 0.21 & $1.05 \mathrm{E}+10$ \\
\hline 1A1T2L4F & Transverse (WG) & $4.20 \mathrm{E}+09$ & 0.21 & $1.01 \mathrm{E}+10$ & 5A1T2L4F & Transverse (WG) & $4.33 \mathrm{E}+09$ & 0.21 & $1.05 \mathrm{E}+10$ \\
\hline 1A1T2L6F & Transverse (WG) & $4.28 \mathrm{E}+09$ & 0.19 & $1.02 \mathrm{E}+10$ & 5A1T2L6F & Transverse (WG) & $4.29 \mathrm{E}+09$ & 0.21 & $1.04 \mathrm{E}+10$ \\
\hline 1AIT3L2F & Transverse (WG) & $4.30 \mathrm{E}+09$ & 0.21 & $1.04 \mathrm{E}+10$ & 5A1T3L2FR & Transverse (WG) & $4.29 \mathrm{E}+09$ & 0.21 & $1.04 \mathrm{E}+10$ \\
\hline 1AIT3L4F & Transverse (WG) & $4.25 \mathrm{E}+09$ & 0.21 & $1.03 \mathrm{E}+10$ & 5A1T3L4F & Transverse (WG) & $4.24 \mathrm{E}+09$ & 0.22 & $1.03 \mathrm{E}+10$ \\
\hline 1AIT3L6F & Transverse (WG) & $4.24 \mathrm{E}+09$ & 0.21 & $1.03 \mathrm{E}+10$ & 5A1T3L6F & Transverse (WG) & $4.37 \mathrm{E}+09$ & 0.21 & $1.06 \mathrm{E}+10$ \\
\hline 1A4T3L2F & Transverse (WG) & $4.12 \mathrm{E}+09$ & 0.19 & $9.80 \mathrm{E}+09$ & 5B3T2L2FR & Transverse (WG) & $4.31 \mathrm{E}+09$ & 0.20 & $1.04 \mathrm{E}+10$ \\
\hline 1A4T3L4F & Transverse (WG) & $4.13 \mathrm{E}+09$ & 0.18 & $9.78 \mathrm{E}+09$ & 5B3T2L4F & Transverse (WG) & $4.28 \mathrm{E}+09$ & 0.20 & $1.03 \mathrm{E}+10$ \\
\hline 1A4T3L6F & Transverse (WG) & $4.24 \mathrm{E}+09$ & 0.19 & $1.01 \mathrm{E}+10$ & 5B3T2L6F & Transverse (WG) & $4.29 \mathrm{E}+09$ & 0.20 & $1.03 \mathrm{E}+10$ \\
\hline 1A4T2L2F & Transverse (WG) & $4.15 \mathrm{E}+09$ & 0.18 & $9.84 \mathrm{E}+09$ & 5B3T3L2F & Transverse (WG) & $4.29 \mathrm{E}+09$ & 0.20 & $1.03 \mathrm{E}+10$ \\
\hline 1A4T2L4F & Transverse (WG) & $4.11 \mathrm{E}+09$ & 0.18 & $9.72 \mathrm{E}+09$ & 5B3T3L4F & Transverse (WG) & $4.25 \mathrm{E}+09$ & 0.20 & $1.02 \mathrm{E}+10$ \\
\hline 1A4T2L6F & Transverse (WG) & $4.08 \mathrm{E}+09$ & 0.18 & $9.64 \mathrm{E}+09$ & 5B3T3L6F & Transverse (WG) & $4.28 \mathrm{E}+09$ & 0.20 & $1.03 \mathrm{E}+10$ \\
\hline 1B2T2L2F & Transverse (WG) & $4.27 \mathrm{E}+09$ & 0.20 & $1.03 \mathrm{E}+10$ & & & & & \\
\hline 1B2T2L4F & Transverse (WG) & $4.29 \mathrm{E}+09$ & 0.20 & $1.03 \mathrm{E}+10$ & & & & & \\
\hline 1B2T2L6F & Transverse (WG) & $4.28 \mathrm{E}+09$ & 0.20 & $1.03 \mathrm{E}+10$ & & & & & \\
\hline 1B2T3L2F & Transverse (WG) & $4.35 \mathrm{E}+09$ & 0.19 & $1.04 \mathrm{E}+10$ & & & & & \\
\hline 1B2T3L4F & Transverse (WG) & $4.22 \mathrm{E}+09$ & 0.21 & $1.02 \mathrm{E}+10$ & & & & & \\
\hline
\end{tabular}


Table A.17. Sonic velocity (TOF) derived elastic constants for graphite grade 2114 billet 116310 in the WG orientation sorted by in-billet location (continued)

\begin{tabular}{|c|c|c|c|c|c|c|c|c|c|}
\hline \multirow{3}{*}{$\begin{array}{c}\text { Specimen } \\
\text { number }\end{array}$} & \multirow{3}{*}{$\begin{array}{c}\text { Grain } \\
\text { orientation }\end{array}$} & \multicolumn{3}{|c|}{ ELASTIC CONSTANTS } & \multirow{3}{*}{$\begin{array}{c}\text { Specimen } \\
\text { number }\end{array}$} & \multirow{3}{*}{$\begin{array}{c}\text { Grain } \\
\text { orientation }\end{array}$} & \multicolumn{3}{|c|}{ ELASTIC CONSTANTS } \\
\hline & & $\begin{array}{c}\text { Shear } \\
\text { modulus, } \\
{[\mathrm{Pa}]}\end{array}$ & $\begin{array}{l}\text { Poisson's } \\
\text { ratio }\end{array}$ & $\begin{array}{c}\text { Poisson's } \\
\text { corrected } \\
\text { elastic } \\
\text { modulus, } \\
\text { [Pa] }\end{array}$ & & & $\begin{array}{c}\text { Shear } \\
\text { modulus, } \\
{[\mathrm{Pa}]}\end{array}$ & $\begin{array}{l}\text { Poisson's } \\
\text { ratio }\end{array}$ & $\begin{array}{c}\text { Poisson's } \\
\text { corrected } \\
\text { elastic } \\
\text { modulus, }[\mathrm{Pa}]\end{array}$ \\
\hline & & $\mathrm{G}_{\rho} \mathrm{v}_{\mathrm{s}}^{2}$ & $\begin{array}{c}\mu=\left(1-\left[2\left(U_{s} I\right.\right.\right. \\
\left.\left.\left.v_{I}\right)^{2}\right]\right) /(2- \\
\left.\left[2\left(U_{s} / v_{I}\right)^{2}\right]\right) \\
\end{array}$ & $\begin{array}{c}E=\rho v^{2}[(1+\mu \\
)(1-2 \mu) /(1- \\
\mu)]\end{array}$ & & & $\mathbf{G}=\rho u_{s}^{2}$ & $\begin{array}{c}\mu=\left(1-\left[2\left(U_{s} /\right.\right.\right. \\
\left.\left.\left.v_{I}\right)^{2}\right]\right) /(2- \\
\left.\left[2\left(U_{s} / v_{I}\right)^{2}\right]\right) \\
\end{array}$ & $\begin{array}{c}E=\rho I^{2}[(1+\mu)(1 \\
-2 \mu) /(1-\mu)]\end{array}$ \\
\hline 1B2T3L6F & Transverse (WG) & $4.19 \mathrm{E}+09$ & 0.20 & $1.01 \mathrm{E}+10$ & & & & & \\
\hline 1B3T2L2F & Transverse (WG) & $4.44 \mathrm{E}+09$ & 0.20 & $1.07 \mathrm{E}+10$ & & & & & \\
\hline 1B3T2L4F & Transverse (WG) & $4.44 \mathrm{E}+09$ & 0.20 & $1.06 \mathrm{E}+10$ & & & & & \\
\hline 1B3T2L6F & Transverse (WG) & $4.35 \mathrm{E}+09$ & 0.20 & $1.04 \mathrm{E}+10$ & & & & & \\
\hline 1B3T3L2F & Transverse (WG) & $4.33 \mathrm{E}+09$ & 0.20 & $1.04 \mathrm{E}+10$ & & & & & \\
\hline 1B3T3L4F & Transverse (WG) & $4.44 \mathrm{E}+09$ & 0.20 & $1.06 \mathrm{E}+10$ & & & & & \\
\hline 1B3T3L6F & Transverse (WG) & $4.36 \mathrm{E}+09$ & 0.21 & $1.05 \mathrm{E}+10$ & & & & & \\
\hline
\end{tabular}


Table A.18. Four-point loading flexure strength for the flex strength specimens from billet 116310, tested here

\begin{tabular}{|c|c|c|c|c|}
\hline \multirow{2}{*}{$\begin{array}{c}\text { Grain } \\
\text { orientation }\end{array}$} & $\begin{array}{l}\text { Flexure } \\
\text { strength }\end{array}$ & \multirow{2}{*}{$\begin{array}{l}\text { Specimen } \\
\text { number }\end{array}$} & \multirow{2}{*}{$\begin{array}{c}\text { Grain } \\
\text { orientation }\end{array}$} & \multirow{2}{*}{$\begin{array}{c}\begin{array}{r}\text { Flexure } \\
\text { strength }\end{array} \\
\mathrm{MPa} \\
\end{array}$} \\
\hline & MPa & & & \\
\hline Parallel (AG) & 39.32 & 1A1T2L2F & Transverse (WG) & 43.79 \\
\hline Parallel (AG) & 38.61 & $1 \mathrm{~A} 1 \mathrm{~T} 2 \mathrm{~L} 4 \mathrm{~F}$ & Transverse (WG) & 42.12 \\
\hline Parallel (AG) & 38.72 & 1A1T2L6F & Transverse (WG) & 40.54 \\
\hline Parallel (AG) & 44.52 & 1AIT3L2F & Transverse (WG) & 43.59 \\
\hline Parallel (AG) & 38.43 & 1AIT3L4F & Transverse (WG) & 43.26 \\
\hline Parallel (AG) & 39.92 & 1AIT3L6F & Transverse $(\mathrm{WG})$ & 44.09 \\
\hline Parallel (AG) & 38.38 & 1A4T3L2F & Transverse (WG) & 43.01 \\
\hline Parallel (AG) & 38.76 & 1A4T3L4F & Transverse (WG) & 41.52 \\
\hline Parallel (AG) & 39.05 & 1A4T3L6F & Transverse (WG) & 41.12 \\
\hline Parallel (AG) & 44.52 & 1A4T2L2F & Transverse (WG) & 37.92 \\
\hline Parallel (AG) & 44.56 & $1 \mathrm{~A} 4 \mathrm{~T} 2 \mathrm{~L} 4 \mathrm{~F}$ & Transverse (WG) & 42.21 \\
\hline Parallel (AG) & 41.24 & 1A4T2L6F & Transverse (WG) & 37.48 \\
\hline Parallel (AG) & 41.83 & 1B2T2L2F & Transverse (WG) & 40.18 \\
\hline Parallel (AG) & 42.80 & 1B2T2L4F & Transverse $(\mathrm{WG})$ & 36.15 \\
\hline Parallel (AG) & 38.21 & 1B2T2L6F & Transverse (WG) & 42.53 \\
\hline Parallel (AG) & 42.08 & 1B2T3L2F & Transverse (WG) & 43.68 \\
\hline Parallel (AG) & 37.19 & 1B2T3L4F & Transverse (WG) & 40.21 \\
\hline Parallel (AG) & 38.51 & 1B2T3L6F & Transverse (WG) & 42.04 \\
\hline Parallel (AG) & 39.89 & 1B3T2L2F & Transverse (WG) & 45.14 \\
\hline Parallel (AG) & 38.77 & 1B3T2L4F & Transverse (WG) & 45.97 \\
\hline Parallel (AG) & 43.18 & 1B3T2L6F & Transverse (WG) & 45.39 \\
\hline Parallel (AG) & 42.32 & 1B3T3L2F & Transverse (WG) & 43.13 \\
\hline Parallel (AG) & 39.24 & 1B3T3L4F & Transverse (WG) & 42.87 \\
\hline Parallel (AG) & 39.39 & 1B3T3L6F & Transverse $(\mathrm{WG})$ & 47.59 \\
\hline Parallel (AG) & 44.89 & 5A1T2L2F & Transverse (WG) & 47.11 \\
\hline Parallel (AG) & 43.99 & 5A1T2L4F & Transverse (WG) & 45.00 \\
\hline Parallel (AG) & 42.22 & 5A1T2L6F & Transverse (WG) & 43.95 \\
\hline Parallel (AG) & 44.13 & 5A1T3L2FR & Transverse (WG) & 45.46 \\
\hline Parallel (AG) & 43.92 & 5A1T3L4F & Transverse (WG) & 45.03 \\
\hline Parallel (AG) & 44.99 & 5A1T3L6F & Transverse (WG) & 43.16 \\
\hline
\end{tabular}


Table A.18. Four-point loading flexure strength for the flex strength specimens from billet 116310, tested here (continued)

\begin{tabular}{|c|c|c|c|c|}
\hline \multirow{2}{*}{$\begin{array}{c}\text { Grain } \\
\text { orientation }\end{array}$} & $\begin{array}{c}\text { Flexure } \\
\text { strength }\end{array}$ & \multirow{2}{*}{$\begin{array}{c}\text { Specimen } \\
\text { number }\end{array}$} & $\begin{array}{c}\text { Grain } \\
\text { orientation }\end{array}$ & $\begin{array}{c}\text { Flexure } \\
\text { strength }\end{array}$ \\
\cline { 2 - 3 } & $\mathbf{M P a}$ & & & MPa \\
\hline Parallel $(\mathrm{AG})$ & 44.24 & 5B3T2L2FR & Transverse (WG) & 47.37 \\
\hline Parallel $(\mathrm{AG})$ & 45.54 & 5B3T2L4F & Transverse (WG) & 41.95 \\
\hline Parallel (AG) & 42.64 & 5B3T2L6F & Transverse (WG) & 46.77 \\
\hline & & & & \\
\hline Parallel $(\mathrm{AG})$ & 48.42 & 5B3T3L2F & Transverse (WG) & 43.68 \\
\hline Parallel $(\mathrm{AG})$ & 49.45 & 5B3T3L4F & Transverse (WG) & 46.07 \\
\hline Parallel $(\mathrm{AG})$ & 46.42 & 5B3T3L6F & Transverse (WG) & 47.17 \\
\hline
\end{tabular}


